\title{
Indexing and Active Fund Management: International Evidence ${ }^{*}$
}

\author{
Martijn Cremers, University of Notre Dame \\ mcremers@nd.edu \\ Miguel A. Ferreira, Nova School of Business and Economics \\ miguel.ferreira@novasbe.pt \\ Pedro Matos, University of Virginia - Darden School of Business \\ matosp@darden.virginia.edu \\ Laura Starks, University of Texas at Austin \\ laura.starks@mccombs.utexas.edu
}

This Version: January 2015

\begin{abstract}
We examine the relation between indexing and active management in the mutual fund industry worldwide. Explicit indexing and closet indexing by active funds are associated with countries' regulatory and financial market environments. We find that actively managed funds are more active and charge lower fees when they face more competitive pressure from low-cost explicitly indexed funds. A quasi-natural experiment using the exogenous variation in indexed funds generated by the passage of pension laws supports a causal interpretation of the results. Moreover, the average alpha generated by active management is higher in countries with more explicit indexing and lower in countries with more closet indexing. Overall, our evidence suggests that explicit indexing improves competition in the mutual fund industry.
\end{abstract}

Keywords: Mutual funds, Active management, Index funds, Exchange-traded funds, Competition, Fees, Performance

JEL classification: G15, G18, G23

\footnotetext{
${ }^{*}$ A previous version of this article was circulated under the title "The Mutual Fund Industry Worldwide: Explicit and Closet Indexing, Fees, and Performance”. We thank Andres Almazan, Wayne Ferson, Javier Gil-Bazo, Fabian Irek, Hao Jiang, Andrew Karolyi, Aneel Keswani, Borja Larrain, Lilian Ng, Henri Servaes, Mikhail Simutin, Sheridan Titman, Michaela Verardo, Albert Wang, Jeffrey Wurgler, and Tong Yao; seminar participants at Arizona State University, Cass Business School, Cornell University, George Washington University, Imperial College, Instituto de Empresa, Rice University, State Street Global Advisors, Stockholm School of Economics-SIFR, Università Cattolica del Sacro Cuore, University of Colorado Boulder, University of Lugano, University of Mannheim, University of Melbourne, University of New South Wales, University of Sidney, University of Southern California, University of Technology Sidney, University of Utah, and University of Virginia-Darden School of Business; and conference participants at the American Finance Association Meetings, China International Conference in Finance, City University of Hong Kong International Conference, European Finance Association Meetings, FMA European Meetings, Inquire Europe Conference, McGill Global Asset Management Conference, Morningstar Europe Conference, Morningstar-Ibbotson Investment Conference, Rothschild Caesarea Center Conference, Rotterdam School of Management Professional Asset Management Conference, SFS Cavalcade Conference, and University of British Columbia Summer Conference for helpful comments. We also thank the sponsors of the S\&P Dow Jones Indices' SPIVA award (runner up). The authors acknowledge financial support from Inquire Europe and the European Research Council.
} 


\section{Introduction}

Practitioners and academics have long debated the societal benefits and degree of competition in the asset management industry, particularly among equity mutual funds. This debate has focused primarily on two dimensions - the relative value of passive versus active management and the question of price competition in the mutual fund industry. ${ }^{1}$ In this paper, we contribute to this debate by examining actively and passively managed equity mutual funds in 32 countries. Elucidating this debate is particularly important because much of the recent growth in assets in the mutual fund industry has been in explicitly indexed equity funds (index funds and exchange-traded funds (ETFs)), which have grown from constituting about $14 \%$ of assets under management in 2002 to about 22\% in 2010. These explicitly indexed funds have thus become a common low-cost alternative for investors to access the stock market, allowing them to buy "beta exposure” (i.e., investing in a diversified portfolio tracking a stock index) at substantially lower fees compared to active funds.

In a Grossman and Stiglitz (1980) world, one would expect passive and active funds to coexist in equilibrium with their relative market shares depending on information costs and overall market efficiency. Thus, the empirical observation of flows into explicitly indexed funds has implications for how such an equilibrium would be expected to change. In particular, Coates and Hubbard (2007) and Khorana and Servaes (2012) suggest that mutual fund markets in the United States and elsewhere are competitive, but that they have different levels of competition. ${ }^{2}$ In

\footnotetext{
${ }^{1}$ For evidence on the value of active management in the mutual fund industry, see, for example, Sharpe (1966), Jensen (1968), Grinblatt and Titman (1989, 1993), Gruber (1996), Wermers (2000), Bollen and Busse (2001), Kacperczyk, Sialm, and Zheng (2005), Avramov and Wermers (2006), Kosowski, Timmermann, Wermers, and White (2006), Kacperczyk and Seru (2007), French (2008), Cremers and Petajisto (2009), and Busse, Goyal, and Wahal (2014). For evidence on competition in the industry, see for example, Elton, Gruber, and Busse (2004), Hortacsu and Syverson (2004), Collins (2005), Coates and Hubbard (2007), Gil-Bazo and Ruiz-Verdu (2009), Wahal and Wang (2011), and Khorana and Servaes (2012).

${ }^{2}$ Some research suggests that perfect competition may not exist in the mutual fund industry or that mutual funds may be perceived as differentiated goods by retail investors due to sizable information/search frictions or investor
} 
addition, Wahal and Wang (2011) show that the entry of new active funds that are close substitutes to incumbent funds creates competitive pressure for the incumbent funds to decrease their fees. We build on this evidence and hypothesize that increasing competition from indexed funds will lead active funds to compete via price (by lowering their fees) and/or product differentiation (by diverging more from their benchmark index). This competitive pressure could benefit fund investors directly through lower fees and indirectly through stronger incentives for skilled active managers to collect information and generate alpha.

The alternative hypothesis is that active and passive fund markets are largely segmented such that investors do not consider these fund types to be substitutes. Rather the investors may perceive active funds as differentiated investment vehicles, which then have higher fees as compensation for alpha generation or for satisfying different investor needs than what is delivered by passive funds. ${ }^{3}$ In this case increasing market shares for indexed funds may not lead to lower fees and higher differentiation by the active funds. Such an outcome would be similar to the "generics paradox" phenomenon in the pharmaceutical industry where researchers have shown that the introduction of generic drugs (which would be analogous to index funds and ETFs in our context) does not necessarily lead to the expected price drops by the branded drugs (which would be analogous to fees of active funds in our context). ${ }^{4}$

In segmented mutual fund markets in which active funds face reduced inflows to their market segment due to the increased presence of index funds, the active funds could increase fees to

irrationality (Elton, Gruber, and Busse, 2004; Hortacsu and Syverson, 2004; Choi, Laibson, and Madrian, 2010; Carlin and Manso, 2011).

${ }^{3}$ Collins (2005) argues that funds may differ, for example, on the services provided to fund shareholders. And even if investors only care about returns, passive funds are not pure substitutes to active funds because of the potential for alpha. Berk and Green (2004) and Pastor and Stambaugh (2012) argue that fund managers may have skill and investors invest in active funds even in the absence of ex post average positive alphas.

${ }^{4}$ The empirical literature on generic drugs finds that generics are cheaper and gain market share, but their entry does not result in lower prices for the branded drugs; see, for example, Frank and Salkever (1997) and Vandoros and Kanovos (2012). The Economist (2014) makes a similar analogy between indexed funds and white-label goods. 
cover higher marketing expenses. Additionally, as the active fund managers care about their relative performance vis-à-vis benchmark indices (Basak and Pavlova, 2013), an increased fear of losing more assets could lead managers to increase the fraction of stocks in the portfolio that belong to their benchmark indices to avoid underperformance. Consistent with this alternative hypothesis, Wurgler (2011) argues that the growth of index-based investing could allow stock prices to be more divorced from the firms' fundamentals, thereby lowering fund managers' incentives to gather information, in which case the managers' funds may perform worse. Thus, the alternative hypothesis posits that an increased market share of indexed funds will lead to active fund managers maintaining their current investment strategy or even becoming less active and resisting downward pressure on their fees. ${ }^{5}$

Our multi-country sample with equity mutual funds and ETFs from 32 countries is an ideal testing ground for these hypotheses due to the wide variation in conditions across markets and the fact that financial markets tend to be segmented across countries (e.g., Stulz, 2005). We consider the segmentation in the mutual fund industry through consideration of the countries in which funds are domiciled or sold. ${ }^{6}$

We first document the extent of explicit indexing in each country, finding considerable crosscountry and time series variation. Over our sample period, the market share of explicitly indexed funds grew from $14 \%$ of assets under management in 2002 to $22 \%$ in 2010 , with the popularity of explicit indexing particularly rising after the 2007-2008 financial crisis. However, not all indexing in mutual funds is necessarily explicit as some so-called "active" funds are largely passively managed, even if their managers market the funds and charge fees as if they are active

\footnotetext{
${ }^{5}$ This argument is based on price effects that are associated with a stock being included in a popular benchmark index. Further, if demand shocks for stocks included in the index lead to sustained price premiums for these stocks, it becomes harder for active managers to outperform by buying stocks that are not included in the index.

${ }^{6}$ The European Union, for example, has adopted the "European passport” system (Directive 2001/107/EC), which facilitates cross-border marketing of mutual funds among European Union member countries.
} 
(a practice that is commonly termed "closet indexing”). To examine this behavior, we use fund portfolio holdings to calculate the Cremers and Petajisto (2009) active share measure, which captures the proportion of a fund's holdings that differs from its benchmark. If fund holdings largely overlap with index holdings, investors are effectively earning index-like gross returns (the beta part of return), which they could obtain at lower fees through explicitly indexed funds. Our results show that closet indexing is common. Defining closet indexers as funds with an active share below 60\% (following the cutoff established in Cremers and Petajisto (2009)), we find that about $20 \%$ of the worldwide mutual fund assets are managed by closet indexers. ${ }^{7}$ Our results are similar when we consider alternative measures of activeness, such as measuring a fund's active share against the portfolio of active funds that track a fund's benchmark. This alternative measure is inspired by the overlap measure of Wahal and Wang (2011).

Our tests regarding the effects of explicit indexing (in terms of market share and shareholder costs) support the hypothesis that increased competition from explicit indexing benefits investors in active funds. Specifically, we find that active funds have higher active shares and charge lower fees in markets with more explicit indexing. In contrast, active funds charge higher fees in countries with more closet indexing. These differences are economically important. For example, a decline in the fees of indexed funds by 50 basis points is associated with 16 basis points lower fees charged by active funds.

One potential concern regarding our empirical tests is that explicitly indexed funds' market shares and costs are likely jointly determined with active funds' active share and fees. We show that the results are robust when we use benchmark and country fixed effects to address the

\footnotetext{
${ }^{7}$ A manager who tries to beat the benchmark should have a minimum active share of at least $50 \%$, since half the assets (by weight) in the benchmark will have a return above the benchmark return (which is the asset-weighted average return of the assets in the benchmark). We obtain consistent results when we use a $50 \%$ cutoff, rather than the $60 \%$ cutoff we use throughout the analysis
} 
concern that the availability of explicit indexing might be related to some unobserved (and time invariant) benchmark or country characteristic that explains the active share and fees of active funds. To further address this potential endogeneity issue we consider a quasi-natural experiment, i.e., the staggered passage of pension legislation in many of the countries in our sample. These Pension Acts generally aim to facilitate a shift from government-sponsored defined-benefit (DB) pension systems towards defined-contribution (DC) pension systems and include policy changes designed to increase market competition, such as easy access to mutual funds that offer market exposure (for example, by offering at least one passive fund in the menu of investment options). The Economist (2014) argues that, with these Pension Acts, “(...) governments are also pushing pension providers to opt for low-cost funds. (....) Such measures make it likely that more investments will flow into tracker funds.” The Pension Acts help to resolve the endogeneity problem to the extent that their timing should be largely related to legislative agendas in particular countries, rather than driven by fund industry conditions.

We use a differences-in-differences estimator that compares the differences in outcomes in the group of countries before and after the year of a country's Pension Act passage versus a control group that includes all countries not passing a Pension Act in the same year. Using this approach, we find that active funds increase their active share and decrease their fees following the passage of a Pension Act in their country of domicile or sale.

Finally, we examine the performance from investing in truly active funds and whether the performance relates to the availability of explicitly indexed products. Thus, we first measure the ability of the active funds in these markets to provide not just beta exposure but to also generate alpha. We find that a fund's active share predicts its future risk-adjusted performance. The effect is economically significant: a one standard deviation increase in active share is associated with 
an increase of about $1 \%$ per year in benchmark-adjusted returns and $0.7 \%$ per year in four-factor alpha. These results for an international sample are consistent with the earlier Cremers and Petajisto (2009) results for the U.S. market.

Next and more importantly, we provide evidence that the average alpha generated by active management is higher in countries where low-cost passive alternatives are more popular, while the average alpha is lower in markets where closet indexing is more prevalent. Overall, our evidence suggests that enhanced competitive pressure from index funds and ETFs creates more incentives for skilled managers to pass on alpha to fund investors whereas closet indexing has the opposite effect.

In sum, our findings suggest that the availability of explicit indexing is associated with improved levels of competition in a fund industry, while closet indexing is indicative of the reverse. Previous evidence regarding competition in the mutual fund industry has primarily focused on the U.S. market (e.g., Wahal and Wang, 2011). The few papers analyzing the mutual fund industry worldwide have so far focused on the determinants of industry size and fees across countries. Khorana, Servaes, and Tufano $(2005,2009)$ find a positive link between the level of development of fund industries worldwide and a combination of legal, regulatory, and demandand supply-side factors. To the best of our knowledge, we are the first to study how indexing is related to the structure and performance of actively managed mutual funds around the world.

\section{Data and Variables}

Our analysis uses two primary databases: Lipper and FactSet/LionShares. The Lipper database provides a comprehensive sample of mutual funds offered across a large number of countries. Mutual funds, while taking a variety of names around the globe, are fairly comparable investment vehicles worldwide (Khorana, Servaes, and Tufano, 2005). We focus exclusively on 
open-end equity mutual funds and exchange-traded funds (ETFs) in the 2002-2010 period. From this database we obtain individual fund characteristics, such as fund name, domicile, sponsor, benchmark, monthly returns, total net assets (TNA), fees, and expenses. The data is survivorship bias-free, as it includes both active and defunct funds. Although multiple share classes are listed as separate observations in Lipper, they have the same holdings and the same returns before expenses. Thus, we keep as our unit of observation the share class that Lipper identifies as the primary share class and aggregate fund-level variables across the different share classes. As we describe below, we also conduct some tests using the individual share classes. ${ }^{8}$

The sample comprises 24,492 funds with a combined TNA totaling over $\$ 9.8$ trillion as of December 2010. This means that mutual funds held roughly $20 \%$ of world stock market capitalization. We identify funds' nationalities by their legal domicile, which characterizes the relevant regulatory and legal system. Table 1 lists the 32 countries with at least 50 funds, including the three countries with off-shore domiciles (Ireland, Liechtenstein, Luxembourg). ${ }^{9}$

The LionShares database covers portfolio equity holdings for institutional investors worldwide, including mutual funds and ETFs. Ferreira and Matos (2008) provide a detailed description of this data source. We match the Lipper (fund characteristics and performance) and LionShares (fund holdings) databases by CUSIP, ISIN or fund name.

Panel A of Table 1 provides key statistics on the sample of funds for which portfolio holdings are available by country of domicile as of December 2010. It shows that detailed holdings are available from LionShares for 11,776 funds with TNA of approximately \$7.9

\footnotetext{
${ }^{8}$ In the European Union, mutual funds fall under the umbrella of UCITS (Undertakings for Collective Investment in Transferable Securities), a regulatory attempt to harmonize investment vehicles across the EU.

${ }^{9}$ Lipper's coverage of funds can be compared with aggregate statistics on mutual funds from other sources. As of December 2010, the Investment Company Institute (2011) reported a total of 27,754 equity mutual funds worldwide with a TNA of \$10.5 trillion. Therefore, we conclude that the Lipper sample is nearly comprehensive of the equity mutual fund universe.
} 
trillion. In total, we have holdings data from the LionShares database for about $81 \%$ of the TNA in the Lipper database, but coverage varies across countries. ${ }^{10}$

We control for fund and country characteristics in our subsequent tests. Table IA.1 in the Internet Appendix provides summary statistics of all variables for the sample of open-end active equity funds in the 2002-2010 period, and Table IA.2 reports time series averages of country variables per country. Appendix A provides all variable definitions.

\section{Explicit and Closet Fund Indexing Around the World}

\subsection{Explicit Indexing}

Panel A of Table 1 reports the number of funds per country using the funds' declared investment type according to their prospectus disclosures as of December 2010. There are a total of 1,218 explicitly indexed funds, which consists of 561 ETFs and 657 traditional index funds with $\$ 1.7$ trillion in assets under management (\$0.8 trillion in ETFs and \$0.9 trillion in index funds) at the end of our sample period. ${ }^{11}$ There are also 10,558 active funds with $\$ 6.2$ trillion in assets under management. Although passively managed funds have become increasingly popular, active funds still vastly dominate mutual fund markets throughout the world.

Before testing our hypotheses on the effects of explicitly indexed funds on a country’s fund industry, we first document the availability of explicitly indexed funds across the different countries. Panel A of Table 1 shows that 22\% of equity mutual fund assets under management worldwide are explicitly indexed as of 2010. For many funds in our sample, the country of domicile corresponds to the single country of sale, while other funds are registered for sale in

\footnotetext{
${ }^{10}$ LionShares' coverage of fund holdings is lower in some countries because disclosure is not mandatory. We obtain similar results when we exclude these countries and conclude that our results are not driven by selective disclosure.

${ }^{11}$ We recognize that ETFs can be used by investors for market timing and other investment strategies beyond purely beta exposure, thus, they may not always be viewed as substitute investment products relative to active funds. Because they are an important source of beta exposure for many investors, we combine them together with index funds and define both as the set of explicitly indexed funds available to investors.
} 
multiple countries. These multi-country registrations create competition across domiciles.

Panel B of Table 1 provides the key statistics for our sample alternatively based on the fund share class by country of sale at the end of our sample period. ${ }^{12}$ While Panel A shows that some countries have no passively managed funds domiciled in their country, Panel B shows that the competitive landscape for funds is much broader when the country of sale is considered because large asset managers domiciled in particular in Ireland (or Luxembourg) offer their index (active) funds across European markets. While both Panels A and B suggest that roughly one-fifth of equity fund assets are explicitly indexed, there is substantial variation across countries. ${ }^{13}$ Because of the different advantages and disadvantages of the two perspectives, we adopt both country of domicile and country of sale in our tests.

\subsection{Active Funds and Closet Indexing}

We differentiate active management versus closet indexing using the active share measure developed by Cremers and Petajisto (2009). The measure represents the share of portfolio holdings that differs from the benchmark index holdings and is calculated as:

$$
\text { Active share }=\frac{1}{2} \sum_{i=1}^{N}\left|w_{\text {fund }, i}-w_{\text {benchmark }, i}\right|
$$

where $w_{\text {fund, } i}$ and $w_{\text {benchmark,i }}$ are the portfolio weights of stock $i$ in the fund and its benchmark index, respectively, and the sum is taken over the universe of stocks. For a mutual fund that does

\footnotetext{
12 Table IA.3 in the Internet Appendix provides details on the number of share classes by country of domicile and country of sale in 2010. Because some funds have multiple share classes and are offered in more than one country, we can have multiple observations for the same fund in a given year. For each fund share class, Lipper provides the list of countries where it is approved for sale but does not have the exact amount of shares that were sold to each market. We basically multiply each fund share class for each country of sale and that causes some duplication. Some aggregate totals in Panel B of Table 1 suffer from this issue.

${ }^{13}$ The calculation of the market share of explicitly indexed funds does not require LionShares holdings data. To investigate the possibility of selection bias from using the sample of 11,776 funds with holdings data in LionShares, we calculate the market share of explicit indexing using the sample of 24,492 funds in Lipper (i.e., including those without holdings data). The degree of explicit indexing is similar to that reported in Table 1.
} 
not short stocks or buy on margin, its active share will always lie between zero and $100 \%{ }^{14}$

Our analysis of active management requires the identification of funds' benchmarks. We use benchmarks independently assigned by Lipper according to their assessment of a fund's investment strategy. ${ }^{15}$ Table IA.4 in the Internet Appendix lists the 88 specific benchmarks, which can be classified into three types: world (funds that invest worldwide), regional (funds that invest in a specific geographic region), and country (funds that invest in a specific country). Some of the world, regional, and country funds may have specific industry or investment styles. We keep only benchmarks with at least $\$ 10$ billion of assets under management in 2010. For some countries with less than $\$ 10$ billion of assets under management, we keep the major country index as the benchmark.

We construct portfolio weights for the 88 different benchmark indices using the aggregate portfolio holdings of the explicitly indexed funds tracking each benchmark. ${ }^{16}$ Therefore, the active share is measured in excess of explicitly indexed funds. Using the actual weights of explicitly indexed funds tracking each benchmark has the advantage that some of the weights in the official benchmark include stocks that, in practice, may not be fully investable by mutual funds due to illiquidity or other constraints. On average (TNA-weighted), active funds in our sample have an active share of $69 \%$, while passive funds have an active share of $16 \%{ }^{17}$

Table 1 and Fig. 1 provide the market share (as a percentage of TNA) of closet indexers and

\footnotetext{
${ }^{14}$ Given our international setting, funds may hold different securities in the same company (e.g., common shares, depository receipts, and dual listings) that represent the same stake in a company. We therefore sum all equity holdings in the same company as part of the portfolio position.

${ }^{15}$ Using the Lipper "Technical Indicator Benchmark" rather than the "Fund Manager Benchmark" (which is selfdeclared by the fund), we avoid the concern that the fund strategically chooses its benchmark. In addition, the Fund Manager Benchmark is sparsely available, which reduces the sample size. However, in unreported analyses, we find similar results with the Fund Manager Benchmark in this smaller sample.

${ }^{16}$ The benchmark weights are calculated excluding synthetic ETFs that do not physically replicate the underlying benchmark index. In addition, for about $2 \%$ of the fund-year observations there are not at least five explicitly indexed funds tracking a particular benchmark. For these cases, we use as an alternative the aggregate portfolio of all active funds that track that benchmark.

${ }^{17}$ Explicitly indexed funds may have non-zero active shares if they do not engage in full physical index replication. For example, passive funds that track the S\&P 500 index have an average active share of $4 \%$.
} 
truly active funds across countries of domicile as of December 2010. We use an active share below $60 \%$ as the cutoff for an active fund to be classified as a closet indexer as in Cremers and Petajisto (2009). ${ }^{18}$ All other funds with active shares equal to or above $60 \%$ are classified as truly active. We find considerable variation in the extent of closet indexing across countries. In countries with little explicit indexing, the active funds are relatively passive. Although in Table 1 we report on active share for the final year in our sample, we find that the active share of funds is an extremely persistent fund attribute over time (the average serial correlation of active share at the fund-level is 0.95). Table IA.5 in the Internet Appendix reports the levels of explicit and closet indexing by country and benchmark type. ${ }^{19}$ Fig. 2 shows the time series of the market shares of explicitly indexed funds, closet indexers and truly active funds over 2002-2010.

\subsection{Fees}

We measure fees and expenses charged to mutual fund shareholders using the total expense ratio (TER) and loads. TER is broader than just management fees and includes all annual expenses that a fund charges its investors for investment management, administration, servicing, transfer agency, audit, and legal costs. Because TER excludes certain distribution fees, such as front-end or back-end loads, we calculate the average annual total shareholder costs (TSC), which is defined as TER plus one-fifth of the front-end load following Khorana, Servaes, and Tufano (2009). This calculation assumes the typical investor holds a fund for five years, and that back-end loads are waived if the fund is held for that length of time. If information on TER is not

\footnotetext{
${ }^{18}$ An active share of $60 \%$ means that $40 \%$ of the fund portfolio weights overlap with the benchmark index weights. The $60 \%$ cutoff is somewhat arbitrary, but as, on average, half the holdings (by asset weight) in any portfolio will beat the portfolio's average return, then an active fund (with a manager who tries to beat the benchmark) should have an active share of at least $50 \%$. In addition, the $60 \%$ threshold corresponds to classifying funds in the bottom tercile of the distribution of active share as closet indexers.

${ }^{19}$ We cannot differentiate between closet indexers that do not attempt to deviate from their benchmarks from those that ex ante commit resources to identify private information but ex post fail in identifying such opportunities. Observationally these cases are equivalent, as both funds exhibit low active share measures.
} 
available (13\% of the fund-year observations), we use instead the annual management fee, which constitutes a lower bound for the TER. ${ }^{20}$

The last three columns of Panels A and B in Table 1 report the (TNA-weighted) average TSC per country for each of the different fund types (explicitly indexed, closet indexers, and truly active) as of the end of 2010. Whether considering country of domicile or country of sale, the costs for explicitly indexed funds are lower than for active funds across all countries. In most countries of domicile, closet indexers are as costly as truly active funds, with an average TSC of $1.64 \%$ and $1.66 \%$ per year, respectively. Fig. 3 illustrates the range of the average TSC across the three types of funds for each country in our sample. These statistics confirm that explicitly indexed funds are a low-cost alternative to active funds worldwide but closet indexers charge fees at par with those of truly active funds.

\section{Determinants of Explicit and Closet Indexing Across Countries}

Explicitly indexed funds provide a low-cost alternative for investors to get beta exposure, while closet indexers offer that same beta exposure but at higher fees. The evidence so far has shown wide variation in the range of fees across countries suggesting that some degree of market segmentation exists. A major influence on market segmentation arises from the funds' location, i.e., the regulatory environment and conditions in the local fund industry. For example, Khorana, Servaes, and Tufano $(2005,2009)$ show that countries with stronger regulations and laws tend to have larger mutual fund industries, lower fund costs and a higher spectrum of funds offered. These results suggest that if competition is driving the effects, then we should find more low-cost explicitly indexed products (and fewer closet indexers) in environments with stronger regulations

\footnotetext{
${ }^{20}$ The TSC ignores annual fees charged by distributers as well as bid-ask spreads in the case of ETFs, which are typically narrow. For example, Morningstar (2012) reports that the Lyxor ETF Euro Stoxx 50 (the largest ETF on the Euro Stoxx 50 index) had a trailing 30-day average spread of 0.017\% at the NYSE Euronext Paris.
} 
and more developed fund industries.

Table 2 provides results on the determinants of explicit and closet indexing across countries over the sample period, where we define the market alternatively by country of domicile (Panel A) and country of sale (Panel B). We use two measures of explicit indexing as dependent variables. Explicit indexing (\% TNA) is the market share of explicitly indexed funds as a percentage of the TNA in each country in a given year. Explicit indexing (average TSC) is the TNA-weighted average total shareholder cost (TSC) of explicitly indexed funds in each country in a given year. We also use a measure of the extent of closet indexing in a market, Closet indexing (\% TNA), which is the market share of active funds with an active share below $60 \%$ as a percentage of the TNA in each country in a given year.

We examine the country-level determinants in separate regressions due to the limited number of country-year observations in our sample. In columns (1), (3), and (5) we test whether indexing is related to regulatory factors (Khorana, Servaes, and Tufano, 2005): the extent to which regulatory approvals are required to set up a fund (Approval) and the quality of a country's judicial system (Judicial). ${ }^{21}$ We find that a more restrictive regulatory approval regime for new funds is positively associated with the availability of explicit indexing. The economic impacts of Approval and Judicial are significant. For example, if one takes the estimates in column (1) of Panel A, an increase in Approval from one to two is associated with an increase of about 6\% in the market share of explicitly indexed funds. Given the relatively low market share of explicitly indexed funds across most countries, this is a large effect. Columns (3) and (5) show that Judicial is negatively associated with both the cost of index funds and the level of closet

\footnotetext{
${ }^{21}$ Approval is the sum of two dummy variables: (1) whether regulatory approval is required to start a fund and (2) whether the prospectus requires regulatory approval. Judicial is the sum of five variables (all variables are scaled between 0 and 10): the efficiency of the judicial system, rule of law, corruption, risk of expropriation, and risk of contract repudiation.
} 
indexing in a country.

We also examine the characteristics of a country's fund industry (Fund industry size, Fund industry Herfindahl) and level of economic development (GDP per capita). Columns (2), (4) and (6) show that industry size is significantly related to the amount of indexing, both explicit and closet indexing: when the fund industry is larger, the higher is the market share of explicitly indexed funds, the lower is the cost, and the less widespread is closet indexing. These results are consistent with the argument that industry development and economies of scale make it easier for low-cost explicitly indexed products to be offered and, at the same time, for closet indexing by active funds to be mitigated. Our argument is that this mitigation is due to changes in the competitive environment caused by the increased presence of explicitly indexed funds.

We also run our regressions with all variables calculated by country of sale. The results reported in Panel B of Table 2 are consistent with those in Panel A. ${ }^{22}$

\section{Explicitly Indexed Funds and Active Funds}

In this section, we study the relation between explicit indexing in a market and the product differentiation (active share) and price that investors pay for active management (total shareholder costs). Specifically, for investors primarily interested in achieving exposure to beta, explicitly indexed funds are low-cost substitutes to the more expensive actively managed funds. If indexed funds create competitive pressure, then we expect active funds facing higher market penetration by indexed products to differentiate themselves by more actively deviating from their benchmarks through stock picking, sector bets, and market timing or by lowering their prices (fees). In alternative, actives funds' behavior may not be affected by indexed funds.

\footnotetext{
${ }^{22}$ In Table IA.6 of the Internet Appendix, we show that results are robust when we further refine the analysis by measuring explicit and closet indexing separately by benchmark type (world, regional, country-domestic, and country-foreign) in each country.
} 
Previous research on mutual fund competition in the United States has arrived at diverse conclusions regarding whether index funds are commodities and should be selling for the same price (e.g., Elton, Gruber, and Busse, 2004; Hortacsu and Syverson, 2004; Collins, 2005). Researchers have also debated whether the U.S. mutual fund industry as a whole is competitive (e.g., Coates and Hubbard, 2007; Gil-Bazo and Ruiz-Verdu, 2009; Wahal and Wang, 2011; Khorana and Servaes, 2012). Our hypotheses focus on the effects of the entry of low-cost passive investment vehicles on the fund industry competitive environment in changes to active funds' product differentiation and fees.

\subsection{Product Differentiation}

To test our hypothesis, we estimate panel regressions using the sample of active equity funds. The dependent variable is the yearly fund-level active share whereas the main explanatory variables are the market share and TNA-weighted average total shareholder costs (TSC) of explicitly indexed funds located in the same country as the fund. We control for fund characteristics, dummies for particular types of funds (international, fund of fund, off-shore), country characteristics and year dummies, and we cluster standard errors by country-year. ${ }^{23}$ Importantly, the regressions also include fund benchmark dummies, which control for any unobserved (time invariant) heterogeneity in portfolio management across different benchmarks.

Table 3 presents the results. Columns (1) and (2) show the results when we measure the indexing variables by country of domicile. Columns (3) and (4) show the results using the individual share class offered for sale in a given country and year as a unit of observation and we measure indexing variables (and other country variables) by country of sale and year. ${ }^{24}$

\footnotetext{
${ }^{23}$ We obtain similar estimates when we use two-way cluster standard errors by country and by year.

${ }^{24}$ This set up takes into account that a fund can be offered for sale in multiple countries. A fund with two share classes, each offered for sale in three countries, will have six different observations per year in this sample. In these tests, fund-level variables are measured at the individual share class level, and country-level variables are measured
} 
In columns (1) and (3) we examine the relation between product differentiation by active funds and the relative prominence of explicitly indexed funds. Although in the analysis using country of domicile we do not find this relation to be significant, in the country of sale analysis shown in column (3) we find that active funds tend to have higher active shares in countries in which explicitly indexed funds have higher market share. Further consistent with our hypothesis, columns (2) and (4) show that the coefficient on the average TSC of explicitly indexed funds is negative and significant. These results suggest that funds tend to engage in more active management in markets where they face more competitive pressure from explicitly indexed funds. The effects are economically meaningful, as we find that a one standard deviation increase in the average TSC of passive funds (0.53) in a country is associated with a decrease in average active share of 1.5 percentage points using the estimate in column (2).

Overall, the tests in Table 3 are consistent with the hypothesis that active fund managers perceive low-cost explicitly indexed funds as a competitive threat. These results also provide additional insights into the organization of mutual fund markets. For example, we find that funds are more active in larger fund markets and countries with higher judicial quality. Further, active shares are higher for funds with higher tracking error (i.e., volatility of the difference between a portfolio return and its benchmark index return), higher TSC, younger funds, and those affiliated to smaller fund families. Moreover, we find that fund managers who have been more successful in the past (in terms of performance and attracting flows) have higher active shares. These results for our international sample of mutual funds are in line with those in Cremers and Petajisto (2009) for U.S. equity mutual funds.

The active share regression results in Table 3 are robust to a number of specification checks.

by the country of sale. In particular, the indexing variables (market share and cost of explicitly indexed funds and the market share of closet indexers) are measured by country of sale. 
In Table IA.7 of the Internet Appendix we estimate the regression using the sample of non-U.S. funds to alleviate any concerns that results are driven by the fact that funds domiciled in the United States represent a large fraction of the observations. We also consider alternative methods to estimate a fund's active share. In particular, we calculate the proportion of a fund's portfolio holdings that differ from the aggregate stock portfolio of active funds that track a fund's benchmark, in the spirit of the overlap measure of Wahal and Wang (2011). ${ }^{25}$ Additionally, we estimate the regression model using weighted least squares, where the total net assets of the fund are employed as the weights and estimate regressions using country fixed effects. Finally, we measure the indexing variables for each country and benchmark type, and consider only the sample of domestic funds.

If fund managers react to the competitive threat of explicitly indexed funds by increasing their active share, then an implication is that they expect higher fund flows from such actions. We test this implication by examining whether mutual funds that offer more distinct portfolios (as proxied by higher active share) attract greater flows. We measure net flows at the annual frequency as the net growth in total net assets (TNA), following the method in Sirri and Tufano (1998). We estimate regression of net flows on prior year active share and fund-level control variables shown in previous research to be related to flows such as prior year TNA, age, TSC, and tracking error (e.g., Sirri and Tufano, 1998; Del Guercio and Tkac, 2002). The regressions also include year and benchmark dummies and standard errors are clustered by country-year.

The relation between flows and active share is likely to be influenced by a fund's past performance, thus, we include an interaction term between active share and the return quintile

\footnotetext{
${ }^{25}$ We also use two alternative methods to calculate active share: (1) we construct the index weights based only on ETFs that engage in full physical replication of the indices (SPDR or iShares ETFs); (2) we assign benchmarks ourselves, taking the most representative benchmark every year for a fund, based on the one against which it has the lowest active share. More details are provided in the Internet Appendix.
} 
ranking of the fund. Following Sirri and Tufano (1998) and Wahal and Wang (2011), the return rank variable is defined as zero for funds in the bottom quintile of performance (over the prior 12 months), one for funds in the middle $60 \%$, and two for funds in the top $20 \%$. The return quintile rankings rely on benchmark-adjusted returns (columns (1) and (3)) or benchmark-adjusted fourfactor alphas (columns (2) and (4)) as measures of fund performance. The benchmark-adjusted return is the difference between the fund's net return and the return on its benchmark (see Section 6 below for details on performance measures). Funds are sorted within each countrybenchmark segment to determine the rankings.

Table 4 presents the estimates of these regressions. Columns (1) and (2) show the estimates by country of domicile and columns (3) and (4) by country of sale. We find that funds with higher active share attract more flows and the effect is even more pronounced among funds that rank high in the performance rankings. The effects are both statistically and economically significant. For example, for a fund in the bottom quintile of performance, the coefficient in column (2) implies that a one-standard deviation increase in active share is associated with $2.7 \%$ higher flows. The results are robust to changing the performance measure and to whether the unit of observation is defined by country of domicile or country of sale.

\subsection{Total Shareholder Costs}

We next test the hypothesis that actively managed fund managers tend to charge (or not) lower fees when they face more competition from (low-cost) explicitly indexed funds. To test this hypothesis, we estimate panel regressions of yearly fund-level total shareholder costs (TSC) using the sample of active funds. The main explanatory variables are the country-level prevalence and average cost of explicit indexing in the country in which the fund is domiciled or offered for sale. We include fund-level active share as a determinant of the TSC, as well as the 
same fund and country characteristics used in Table 3. Regressions also include year and fund benchmark dummies and standard errors are clustered by country-year.

Table 5 presents the results by country of domicile in columns (1)-(3) and by country of sale in columns (4)-(6). We find that the TSC charged by active funds are higher in countries where explicitly indexed funds have less market share and are more expensive. The effect of the market share of explicitly indexed funds is statistically significant only when we define the indexing variable by country of sale in column (4). The effect of the cost of explicitly indexed funds is statistically significant in both columns (2) and (5). The estimates in column (2) show that a decline in the average TSC of indexed funds of 50 basis points (the difference in TSC between U.S. and non-U.S. funds) is associated with 16 basis point lower fees charged by active funds. Overall, the results suggest that investors pay a higher price for active funds in markets where explicitly indexed products exert less competitive pressure.

Columns (3) and (6) of Table 5 show that active fund fees are higher in markets where closet indexing is more pervasive. According to estimates in column (3), an increase in the level of closet indexing of 15 percentage points (the difference between the United States and the rest of the world) is associated with an increase in the funds' TSC of about 4 basis points. This indicates that closet indexing reflects a less competitive fund industry in which funds extract higher fees.

We additionally find that fund characteristics matter for a fund's total shareholder costs. Higher active share, higher tracking error, smaller and older funds are associated with greater fees. Consistent with the evidence in Khorana, Servaes and Tufano (2009), fees are lower in stronger regulatory environments and when fund industries are larger. ${ }^{26}$

\footnotetext{
${ }^{26}$ We subject these TSC regressions to a number of robustness checks. In Table IA.8 of the Internet Appendix we consider the sample of non-U.S. funds, as well as alternative measures of active share, weighted least squares, country fixed effect, analysis by country-benchmark type, and restricting the sample to domestic funds. We conclude that the total shareholder cost regression results are robust to these checks.
} 


\subsection{Endogeneity}

A potential concern with our findings is endogeneity, that is, the active share and fees charged by active funds are likely jointly determined with the market share and cost of explicitly indexed funds (and closet indexers). So far, we have used funds' benchmarks or country fixed effects to address the concern that the availability of explicit indexing might be related to some unobserved (time invariant) benchmark or country characteristic that explains the active share and fees of active funds.

In this section, we consider a quasi-natural experiment to identify the causal effects of indexed funds on the behavior of active funds. We explore the exogenous variation in competitive pressure from explicitly indexed funds that results from the staggered passage of pension legislation in a fund's country. We argue that the shift observed in many countries towards defined contribution (DC) pension system has contributed to the rise of index funds and ETFs. In fact, the Pension Acts generally include policy changes designed to increase market competition such as providing investors' easy access to low-cost funds. One example is in the United Kingdom which allowed workers to opt out of the occupational pension plan of their employers and created the National Employment Savings Trust (NEST). According to The Economist (2014), “(...) As part of a plan to nudge people into taking out private pensions, known as auto-enrolment, the British government set up a collective scheme called NEST, with annual fees that equate to just $0.5 \%$. Such measures make it likely that more investments will flow into tracker funds.”

The key assumption of our identification strategy is that pension reforms are not related to the conditions of the mutual fund industry in each country, other than through changes in the availability of explicitly indexed funds. For example, these Pension Acts help us to avoid the 
endogeneity problem to the extent that their timing is a result of the legislative agenda in the various countries, rather than driven by particular countries' fund industry conditions. According to the Organization for Economic Co-operation and Development (2011) (OECD) population aging and the fiscal sustainability of public systems have been the main driving forces behind pension reforms. For the last two decades, the pension framework has changed from mostly defined-benefit plans (either public retirement or employer-provided private pension plans) to private defined-contribution plans in which the investment and longevity risk are borne by plan participants rather than governments or employers.

Media coverage at the times of the legislative changes illustrates this. For example, shortly before the 2001 legislative change in Japan, the Economist Intelligence Unit discusses the size of the Japanese pension market, the country's aging trend and the government's plans for reform to solve these problems: "As part of a long-term solution, the government plans to introduce a defined-contribution pension scheme that would pay benefits based on investment returns.,27 Similarly, the discussion in the press about Norway's reforms also focused on the changing demographics and the need for change, "Norway’s Parliament is set to vote on legislation aimed at securing the future of the pension system during a time of demographic change. At its core, the bill transfers part of the cost of pensions from the state system to employers. ${ }^{28}$

We collect the year of the passage of the Pension Act for each country from the Organization for Economic Co-operation and Development (2009). Table IA.2 in the Internet Appendix provides the year of the Pension Act passage in each country. ${ }^{29}$ We restrict the sample to countries that passed the Pension Act in the 1990s or 2000s. We first check whether the passage

\footnotetext{
${ }^{27}$ See Economist Intelligence Unit (1999).

${ }^{28}$ Wall Street Journal (2005).

${ }^{29}$ In the instances in which there are multiple dates of passage of Pension Act legislation in a country, we choose the earliest date.
} 
of a Pension Act in a country appears to be associated with increased competition for active funds due to changes to the market share and cost of explicitly indexed funds. Panels A and B of Fig. 4 display the evolution of the market share and the average TSC of explicitly indexed funds, respectively, around the passage of the Pension Act (between year -1 and year 0 ) for the treatment group (i.e., countries that passed a pension act in year $t$ ) and the control group (i.e., countries that did not pass a pension act in year $t$ ). The market share of explicitly indexed funds in the treatment group increases from 5.5\% three years prior to the event to about $9 \%$ three years after the event. In parallel, the average TSC of explicitly indexed funds in the treatment group decreases from about $1 \%$ three years before the event to about $0.85 \%$ three years after the event. In contrast, the market share and average TSC of indexed funds in a country that did not pass a pension act in that year do not show significant changes in the year of the Pension Act passage. These findings suggest that Pension Act legislation is associated with increased availability of low-cost passive investment alternatives.

We next examine the corresponding response of actively managed funds by comparing the outcomes in each country that passed a Pension Act in the years before versus the years after passage. We use the group of countries without pension legislative changes over that year to control for changes in fund industry conditions in a regression framework. As a result, we compare the differences in outcome variables in the treatment group of countries before and after the year of the Pension Act passage to the differences in those variables for the control group of countries over the same period. These differences in differences provide estimates of how the passage of Pension Acts affected the decisions of the active funds located in the country. The regression accounts for the fact that there are many Pension Acts staggered over time. Because the regression implicitly takes all countries not passing an Act at time $t$ as a control group, even 
if they already passed an Act or will pass one later on, it accounts for the fact that the passage of the Pension Acts is staggered over time. The regressions also include year dummies to control for aggregate changes in stock markets and the fund industry.

Table 6 reports the estimates from the differences-in-differences regressions where the dependent variables are the active share (columns (1)-(3)) and total shareholder cost (columns (4)-(6)) of active funds. Again we report two sets of results. Panel A reports estimates by country of domicile, and Panel B reports estimates by country of sale. The explanatory variable of interest is the Post pension act (year $>=0$ ), a dummy variable that takes the value of one if a Pension Act has been passed in the fund's country by year $t$. Thus, the coefficient on the Post pension act (year $>=0$ ) variable estimates the impact of the Pension Act on the active share and TSC. The regression controls for time invariant differences between funds in the treatment versus the control groups through fund fixed effects.

Column (1) in Panels A and B report the estimated impact of the passage of a Pension Act on the active share of active funds in that country. On average, in the years after the act is passed, funds increase their active shares by $1.3 \%$ for the country of domicile analysis in Panel A and $1.5 \%$ to $2 \%$ for the country of sale analysis in Panel B. The coefficients are statistically significant. In column (2) in both panels, we show that the active share effect of the acts remains robust to the inclusion of time-varying fund controls such as TNA, age, and flows.

In column (3), we provide further evidence regarding the potential issues of reverse causality and industry-level confounding effects and specifically to what extent any pre-existing trends are present in the years before the Pension Acts were passed. Specifically, we replace the Post pension act dummy variable with four dummy variables: Pre pension act $(-3<=$ year $<=-1)$ is a dummy variable that equals one if a fund's country passes a pension act in three years, two years 
or one year; Post pension act (year 0) is a dummy variable that equals one if a fund's country passes a pension act in the current year; Post pension act (year 1) is a dummy variable that equals one if a fund's country passed a pension act in the previous year; and Post pension act (year $>=2$ ) is a dummy variable that equals one if a fund's country passed a pension act two years ago or more. The variable Pre pension act $(-3<=$ year $<=-1)$ allow us to evaluate whether an effect on funds' active shares can be found prior to the passage of the Pension Act, which could indicate some reverse causality. We find that the coefficient on Pre pension act $(-3<=$ year $<=-1$ ) is statistically insignificant, while we find that the coefficients on Post pension act (year 0 ) and Post pension act (year 1) and Post pension act (year >=2) are positive and significant. Further, the Post pension act (year 1) and Post pension act (year >=2) coefficients are economically larger than that on Pension act (year 0), which is consistent with a causal interpretation of the effect of the passage of the Pension Act on active share.

Columns (4)-(6) in Panels A and B present estimates of similar specifications for the TSC of active funds by country of domicile and sale. In both cases, we find that subsequent to the act being passed, the active funds reduce the TSC by 3 to 5 basis points, reductions that are statistically significant at the 5\% level. Further, the coefficient on Pre pension act $(-3<=$ year $<=-$ 1) is statistically insignificant, while the coefficients on Post pension act (year 1) and Post pension act (year $>=2$ ) are economically larger than that on Pension act (year 0 ). These results are consistent with Pension Acts having causal effects on shareholder costs and they rule out the existence of pre-trends.

Given the concern that pre-trends might exist in the outcome variables (active share and TSC of active funds) for the treatment group relative to the control group, Fig. 5 plots the coefficients on these variables equivalent to those in columns (3) and (6) in Table 6, Panel B, but including 
yearly leads and lags of the Post pension act dummy variable. Panel A presents estimates in which the dependent variable is the active share, and Panel B presents estimates in which the dependent variable is the TSC of active funds. Both panels show no differentials in the trends between the treated and control groups prior to the Pension Act passages, but sharp differences emerge after the Pension Act legislation.

We conduct other sensitivity tests of our differences-in-differences estimates. First, we report the results of tests of changes in fund industry conditions (industry concentration) that could correlate with the outcome variables in column (7) of Panels A and B. These results show no statistically significant differences in the periods before and after the passage of the Pension Acts. Second, we perform placebo tests using countries that have not approved a Pension Act as a fictitious treatment group and randomly assigning them years in which a Pension Act was approved (i.e., a year between 2002 and 2007). The results show no statistical significant effects in the outcomes variables. Finally, we implement an instrumental variables approach as another way to address the potential endogeneity in our original tests, using the financial sophistication of retail investors in a country and the development of the DC pension market as instruments. The results in Tables IA.9 and IA.10 of the Internet Appendix are consistent with those in Tables 3 and 5. Overall, the results of all these sensitivity tests support the interpretation of a causal effect of explicitly indexed funds on active funds.

\section{Returns to Active Management}

In this section, we test whether investors benefit from the changing fund industry dynamics. That is, we examine whether performance from investing in truly active funds improves as competition from explicit index funds increases. We first examine benchmark-adjusted returns (i.e., the difference between the fund's net return and the return on its benchmark). The average 
benchmark-adjusted net return for all active funds in our sample is approximately zero, consistent with results in other studies of mutual fund performance and also consistent with the Berk and Green (2004) theory of active fund management. We find that truly active funds significantly outperform closet indexers. Further, we find that the truly active funds are able to outperform their benchmarks on average by $1.04 \%$ per year (0.12\% if equal-weighting).

We next examine whether active share predicts future fund performance using benchmarkadjusted four-factor alphas as our measure of performance. The four-factor alphas are estimated using three years of past monthly fund (benchmark-adjusted) returns with regional factors (Asia, Europe, North America, and Emerging Markets) or world factors in the case of world funds in the manner of Bekaert, Hodrick, and Zhang (2009). Ferreira, Keswani, Miguel, and Ramos (2013) provide details on the construction of the factors. We then subtract the expected return from the realized fund return to estimate the fund abnormal return (alpha) in each year, which is measured as the sum of the intercept of the model and the residual as in Carhart (1997). We then regress four-factor alphas on active share and fund and country characteristics in pooled regressions. All independent variables are measured with a one-year lag. The regressions also include benchmark and year dummies, and standard errors are clustered by country-year.

Table 7 reports the results. Panel A reports estimates when indexing variables and other country variables are measured by country of domicile, while Panel B reports estimates when these variables are measured by country of sale and the unit of observation is a fund share class offered for sale in each country. Column (1) shows that funds with higher active share perform better. Thus, active share is a predictor of future fund performance across world markets, consistent with the Cremers and Petajisto (2009) results for U.S. equity mutual funds. The effect of active share on future fund performance is both statistically and economically significant. A 
one standard deviation increase in active share is associated with a $0.7 \%$ increase in four-factor alphas in the subsequent year using the estimate in column (1), Panel A.

Table 7 also shows that tracking error (an alternative measure of active management) is actually negatively related to future fund performance. This suggests that the market rewards funds that are most active in stock picking (which is captured by active share) but does not reward factor bets (which is captured by tracking error). The coefficients of the other fund characteristics are consistent with previous findings for the U.S. mutual fund literature. Fund size is negatively related to performance, while family size is positively related (Chen, Hong, Huang, and Kubik, 2004). Total shareholder costs are negatively related to performance (Malkiel, 1995; Carhart, 1997; and Gil-Bazo and Ruiz-Verdu, 2009).

Table IA.11 in the Internet Appendix shows that estimates are consistent using different fund performance measures commonly used in the literature (benchmark-adjusted returns, excess return four-factor alphas, and information ratio). For example, we estimate that a one standard deviation increase in active share is associated with a 1\% increase in future benchmark-adjusted returns. Table IA.11 also shows that funds with higher active share perform better using the sample of non-U.S. funds, weighted least squares, country fixed effects, the sample of domestic funds, alternative active share measures (the pure-ETF active share and the minimum active share), and controlling for the Amihud and Goyenko (2013) R-squared measure.

We next test the hypothesis that the presence of passive funds affects the returns to active management. To test this, in the performance regressions we include the market shares and average cost of explicit indexing and closet indexing and the interactions of these variables with a fund's active share. Columns (2)-(4) of Table 7 present the estimates of these regressions. We find that fund performance is positively related to the market share of explicitly indexed funds in 
column (2) of Panel B and negatively related to the average cost of explicit indexing in column (3) in both Panels A and B. It suggests that active funds perform better in markets where lowcost explicitly indexed funds are more available. This finding is consistent with the idea that enhanced competition by low-cost explicitly indexed funds spurs active funds to deliver better after-fee performance to investors. Moreover, the coefficient on the interaction between active share and the market share of explicitly indexed funds is negative and significant (in Panel B) and the interaction of active share and the average TSC of explicitly index funds is positive and significant (in both Panels A and B). We thus conclude that the marginal returns to active management are lower in markets with more prevalent and cheaper explicitly indexed funds.

The coefficient on the market share of closet indexing is negative and significant in column (4) of Panel B, while the interaction term with active share is positive and significant. These findings suggest that funds perform worse in markets in which so-called active funds are actually more generally passive with a consequent less competitive environment.

Finally, we examine the implication that the pension legislation should have resulted in changes in active fund performance by extending the differences-in-differences analysis. The results, reported in Table IA.12 of the Internet Appendix, show that the coefficient on the Post pension act (year $>=0$ ) variable is positive and significant, which indicates that performance improves more for the treatment group funds than for the control group funds following the passage of the Pension Act. These results are consistent with those reported in Table 7.

\section{Conclusion}

We examine the consequences of indexing in the equity mutual fund industry across 32 countries. We test the hypothesis that growth in explicit indexing affects the competitive structure of mutual fund markets by forcing actively managed mutual funds to increase their 
active share (deviate more from the benchmark) and to lower their fees. Our evidence is consistent with this hypothesis. Markets with more competition from explicitly indexed funds display active funds that pursue more differentiated product strategies (i.e., funds exhibit higher active shares) to deliver alpha to investors and charge lower fees for active management. In contrast, in countries in which investors have limited options of paying lower fees for beta exposure through passive management, many active fund managers are effectively closet indexers who charge higher fees and underperform. A quasi-natural experiment using the exogenous variation in the availability of indexed funds generated by the country adoption of defined-contribution pension systems supports a causal interpretation of the results.

The primary implication of these results is that the growth of explicitly indexed funds worldwide enhances competition in the asset management industry. Further, the continued growth of index-based investing could have broader implications for markets and asset prices, which deserves increased attention from future research. 


\section{References}

Amihud, Y., Goyenko, R., 2013. Mutual fund's $\mathrm{R}^{2}$ as predictor of performance. Review of Financial Studies 26, 667-694.

Avramov, D., Wermers, R., 2006. Investing in mutual funds when returns are predictable. Journal of Financial Economics 81, 339-377.

Basak, S., and Pavlova, A., 2013. Asset prices and institutional investors. American Economic Review 103, 1728-1758.

Bekaert, G., Hodrick, R., Zhang, X., 2009. International stock return comovements. Journal of Finance 64, 2591-2626.

Berk, J., Green, R., 2004. Mutual fund flows and performance in rational markets. Journal of Political Economy 112, 1269-1295.

Bollen, N., Busse, J., 2001. On the timing ability of mutual fund managers. Journal of Finance 56, 1075-1094.

Busse, J., Goyal, A., Wahal, S., 2014. Investing in a global world. Review of Finance 18, 561590.

Carhart, M., 1997. On persistence in mutual fund returns. Journal of Finance 52, 57-82.

Carlin, B., Manso, G., 2011. Obfuscation, learning, and the evolution of investor sophistication. Review of Financial Studies 24, 754-785.

Chen, J., Hong, H., Huang, M., Kubik, J., 2004. Does fund size erode mutual fund performance? The role of liquidity and organization. American Economic Review 94, 1276-1302. 
Choi, J., Laibson, D., Madrian, B., 2010. Why does the law of one price fail? An experiment on index mutual funds. Review of Financial Studies 23, 1405-1432.

Coates, J., Hubbard, R. G., 2007. Competition and shareholder fees in the mutual fund industry: Evidence and implications for policy. Journal of Corporation Law 33, 151-222.

Collins, S., 2005. Are S\&P 500 index mutual funds commodities? Investment Company Institute Perspective 11, 1-11.

Cremers, M., Petajisto, A., 2009. How active is your fund manager? A new measure that predicts performance. Review of Financial Studies 22, 3329-3365.

Del Guercio, D., Tkac, P., 2002. The determinants of the flow of managed portfolios: mutual funds vs. pension funds. Journal of Financial and Quantitative Analysis 37, 523-557.

Economist, 2014. Fund management - Will invest for food, May 3.

Economist Intelligence Unit - Viewswire, 1999. Japan finance - Search begins for pension plan solutions. July 7.

Elton, E., Gruber, M., Busse, J., 2004. Are investors rational? Choices among index funds. Journal of Finance 59, 261-288.

Ferreira, M., Matos, P., 2008. The colors of institutions' money: The role of institutional investors around the world, Journal of Financial Economics 88, 499-533.

Ferreira, M., Keswani, A., Miguel, A., Ramos, S., 2013. The determinants of mutual fund performance: A cross-country study. Review of Finance 17, 483-525.

Frank, R., Salkever, D., 1997.Generic entry and the pricing of pharmaceuticals. Journal of Economics and Management Strategy 6, 75-90. 
French, K., 2008. Presidential address: The cost of active investing. Journal of Finance 63, 15371573.

Gil-Bazo, J., Ruiz-Verdu, P., 2009. The relation between price and performance in the mutual fund industry. Journal of Finance 64, 2153-2183.

Grinblatt, M., Titman, S., 1989. Mutual fund performance: An analysis of quarterly portfolio holdings. Journal of Business 62, 393-416.

Grinblatt, M, Titman, S., 1993. Performance measurement without benchmarks: An examination of mutual fund returns. Journal of Business 66, 47-68.

Grossman, S., Stiglitz, J., 1980. On the impossibility of informationally efficient markets. American Economic Review 70, 393-408.

Gruber, M, 1996. Another puzzle: The growth in actively managed mutual funds. Journal of Finance 51, 783-810.

Hortacsu, A., Syverson, C., 2004. Product differentiation, search costs, and competition in the mutual fund industry: A case study of S\&P 500 index funds. Quarterly Journal of Economics 119, 403-456.

Investment Company Institute, 2011. Investment Company Fact Book.

Jensen, M., 1968. The performance of mutual funds in the period 1945-1964. Journal of Finance 23, 389-416.

Kacperczyk, M., Seru, A., 2007. Fund manager use of public information: New evidence on managerial skills. Journal of Finance 62, 485-528. 
Kacperczyk, M., Sialm, C., Zheng, L., 2005. On the industry concentration of actively managed equity mutual funds. Journal of Finance 60, 1983-2011.

Khorana, A., Servaes, H., 2012. What drives market share in the mutual fund industry? Review of Finance 16, 81-113.

Khorana, A., Servaes, H., Tufano, P., 2005. Explaining the size of the mutual fund industry around the world. Journal of Financial Economics 78, 145-185.

Khorana, A., Servaes, H., Tufano, P., 2009. Mutual fund fees around the world. Review of Financial Studies 22, 1279-1310.

KPMG, 2011. Defined contribution pensions: A global solution to pension funding challenges.

Kosowski, R., Timmermann, A., Wermers, R., White, H., 2006. Can mutual fund stars really pick stocks? New evidence from a bootstrap analysis. Journal of Finance 61, 2551-2595.

La Porta, R., Lopez-de-Silanes, F., Shleifer, A., Vishny, R., 1998. Law and finance. Journal of Political Economy 106, 1113-1155.

Malkiel, B, .1995. Returns from investing in equity mutual funds 1971 to 1991 . Journal of Finance 50, 549-572.

Morningstar, 2012. Total cost of ETF ownership: The bid-offer spread. February 28.

Organisation for Economic Co-operation and Development, 2009. Private Pensions Outlook 2008. OECD Publishing.

Organisation for Economic Co-operation and Development, 2011. Pensions at a Glance 2011: Retirement-income Systems in OECD and G20 Countries. OECD Publishing. 
Pastor, L., Stambaugh, R., 2012. On the size of the active management industry. Journal of Political Economy 120, 740-781.

Sharpe, W., 1966. Mutual fund performance. Journal of Business 39, 119-138.

Sirri, E., Tufano, P., 1998. Costly search and mutual fund flows. Journal of Finance 53, 15891622.

Stulz, R., 2005. The limits of financial globalization. Journal of Finance 60, 1595-1638.

Vandoros, S., Kanavos, P., 2012. The generics paradox revisited: Empirical evidence from regulated markets. Applied Economics 45, 3230-3239.

Wall Street Journal, 2005. Norway to mandate private pensions. December 19.

Wahal, S., Wang, A., 2011. Competition among mutual funds. Journal of Financial Economics 99, 40-59.

Wermers, R., 2000. Mutual fund performance: An empirical decomposition into stock-picking talent, style, transactions costs, and expenses. Journal of Finance 55, 1655-1695.

Wurgler, J., 2011. On the economic consequences of index-linked investing. In: Rosenfeld, G., Lorsch, J., Khurana, R. (Ed), Challenges to Business in the Twenty-First Century: The Way Forward, American Academy of Arts and Sciences. 
Table 1

Explicit and closet indexing by country of domicile and country of sale

This table presents the number of funds and TNA in billions of U.S. dollars per country as of December 2010 for the sample of open-end equity mutual funds in Lipper for which holdings are available in LionShares. Explicit indexing includes index funds and exchange-traded funds. Closet indexing includes active funds with active share below 0.6. Truly active includes active funds with active share above 0.6. Total shareholder cost is the annual total expense ratio plus one-fifth of the front-end load. Panel A presents statistics based on the primary fund country of domicile and Panel B presents statistics based on the fund share class country of sale.

\begin{tabular}{|c|c|c|c|c|c|c|c|c|c|c|c|c|}
\hline \multicolumn{13}{|c|}{ Panel A: By country of domicile } \\
\hline & \multicolumn{2}{|c|}{ Funds with holdings } & \multicolumn{2}{|c|}{ Explicitly indexed funds } & \multicolumn{2}{|c|}{ Active funds } & \multicolumn{3}{|c|}{ Market share (\% TNA) } & \multicolumn{3}{|c|}{ Total shareholder cost (\%) } \\
\hline & Number & $\begin{array}{c}\text { TNA } \\
\text { (\$ billion) }\end{array}$ & Number & $\begin{array}{c}\text { TNA } \\
\text { (\$ billion) }\end{array}$ & Number & $\begin{array}{c}\text { TNA } \\
\text { (\$ billion) }\end{array}$ & $\begin{array}{l}\text { Explicit } \\
\text { indexing }\end{array}$ & $\begin{array}{c}\text { Closet } \\
\text { indexing }\end{array}$ & $\begin{array}{l}\text { Truly } \\
\text { active }\end{array}$ & $\begin{array}{c}\text { Explicit } \\
\text { indexing }\end{array}$ & $\begin{array}{c}\text { Closet } \\
\text { indexing }\end{array}$ & $\begin{array}{l}\text { Truly } \\
\text { active }\end{array}$ \\
\hline Austria & 167 & 15.0 & 11 & 0.5 & 156 & 14.5 & 3 & 36 & 61 & 2.23 & 2.58 & 2.61 \\
\hline Belgium & 150 & 17.9 & 24 & 3.7 & 126 & 14.2 & 21 & 43 & 36 & 1.16 & 2.01 & 1.98 \\
\hline Canada & 895 & 326.4 & 53 & 24.4 & 842 & 302.0 & 8 & 37 & 55 & 0.42 & 2.11 & 2.80 \\
\hline Denmark & 201 & 30.5 & 12 & 0.5 & 189 & 30.0 & 2 & 27 & 71 & 0.83 & 1.87 & 2.09 \\
\hline Finland & 147 & 26.2 & 8 & 0.8 & 139 & 25.4 & 3 & 44 & 53 & 0.34 & 2.16 & 1.91 \\
\hline France & 492 & 134.1 & 89 & 33.8 & 403 & 100.3 & 25 & 29 & 46 & 0.77 & 2.07 & 2.22 \\
\hline Germany & 356 & 139.5 & 51 & 22.3 & 305 & 117.2 & 16 & 34 & 50 & 0.69 & 2.34 & 2.37 \\
\hline Ireland & 484 & 222.5 & 62 & 68.8 & 422 & 153.7 & 31 & 25 & 44 & 0.56 & 1.89 & 2.17 \\
\hline Italy & 125 & 31.4 & 0 & 0.0 & 125 & 31.4 & 0 & 36 & 64 & & 2.44 & 2.59 \\
\hline Liechtenstein & 101 & 6.0 & 0 & 0.0 & 101 & 6.0 & 0 & 18 & 82 & & 1.70 & 1.98 \\
\hline Luxembourg & 2,057 & 750.5 & 107 & 30.7 & 1,950 & 719.8 & 4 & 26 & 70 & 1.21 & 2.60 & 2.43 \\
\hline Netherlands & 75 & 33.6 & 3 & 0.3 & 72 & 33.3 & 1 & 21 & 78 & 0.59 & 1.40 & 1.30 \\
\hline Norway & 117 & 41.4 & 8 & 2.6 & 109 & 38.8 & 6 & 26 & 68 & 0.42 & 1.44 & 1.82 \\
\hline Poland & 46 & 8.4 & 0 & 0.0 & 46 & 8.4 & 0 & 58 & 42 & & 4.02 & 3.00 \\
\hline Portugal & 53 & 2.0 & 1 & 0.0 & 52 & 2.0 & 0 & 39 & 61 & 1.03 & 2.01 & 2.08 \\
\hline Spain & 267 & 13.1 & 27 & 1.2 & 240 & 11.9 & 9 & 42 & 49 & 1.51 & 2.12 & 1.97 \\
\hline Sweden & 266 & 113.5 & 36 & 11.7 & 230 & 101.8 & 10 & 56 & 34 & 0.56 & 1.47 & 1.42 \\
\hline Switzerland & 220 & 69.7 & 45 & 40.6 & 175 & 29.1 & 58 & 24 & 18 & 1.01 & 1.73 & 2.08 \\
\hline United Kingdom & 975 & 504.1 & 46 & 45.6 & 929 & 458.5 & 9 & 32 & 59 & 0.62 & 2.33 & 2.38 \\
\hline United States & 3,153 & $5,150.3$ & 547 & 1,393.2 & 2,606 & $3,757.1$ & 27 & 15 & 58 & 0.26 & 1.07 & 1.31 \\
\hline Asia Pacific & 1,204 & 255.5 & 86 & 62.3 & 1,118 & 193.2 & 24 & 20 & 56 & 0.75 & 1.46 & 1.90 \\
\hline Other Regions & 225 & 29.3 & 2 & 0.1 & 223 & 29.2 & 0 & 41 & 59 & 1.35 & 2.14 & 2.08 \\
\hline Total & 11,776 & 7,921.1 & 1,218 & $1,743.2$ & 10,558 & $6,177.9$ & 22 & 20 & 58 & 0.35 & 1.64 & 1.66 \\
\hline
\end{tabular}


Table 1 (continued)

\begin{tabular}{|c|c|c|c|c|c|c|c|c|c|c|c|c|}
\hline \multicolumn{13}{|c|}{ Panel B: By country of sale } \\
\hline & \multicolumn{2}{|c|}{ Funds with holdings } & \multicolumn{2}{|c|}{ Explicitly indexed funds } & \multicolumn{2}{|c|}{ Active funds } & \multicolumn{3}{|c|}{ Market share (\% TNA) } & \multicolumn{3}{|c|}{ Total shareholder cost (\%) } \\
\hline & Number & $\begin{array}{c}\text { TNA } \\
\text { (\$ billion) }\end{array}$ & Number & $\begin{array}{c}\text { TNA } \\
\text { (\$ billion) }\end{array}$ & Number & $\begin{array}{c}\text { TNA } \\
\text { (\$ billion) }\end{array}$ & $\begin{array}{l}\text { Explicit } \\
\text { indexing }\end{array}$ & $\begin{array}{c}\text { Closet } \\
\text { indexing }\end{array}$ & $\begin{array}{l}\text { Truly } \\
\text { active }\end{array}$ & $\begin{array}{c}\text { Explicit } \\
\text { indexing }\end{array}$ & $\begin{array}{c}\text { Closet } \\
\text { indexing }\end{array}$ & $\begin{array}{l}\text { Truly } \\
\text { active }\end{array}$ \\
\hline Austria & 5,861 & 1,020 & 269 & 114.9 & 5,592 & 904.9 & 11 & 24 & 65 & 0.76 & 2.61 & 2.53 \\
\hline Belgium & 3,301 & 519 & 154 & 20.9 & 3,147 & 498.1 & 4 & 27 & 69 & 0.90 & 2.82 & 2.74 \\
\hline Canada & 2,114 & 326 & 82 & 24.3 & 2,032 & 302.1 & 7 & 37 & 55 & 0.41 & 2.11 & 2.78 \\
\hline Denmark & 2,741 & 476 & 65 & 55.8 & 2,676 & 420.6 & 12 & 26 & 62 & 0.53 & 2.65 & 2.58 \\
\hline Finland & 3,973 & 582 & 115 & 35.9 & 3,858 & 545.8 & 6 & 28 & 66 & 0.88 & 2.67 & 2.56 \\
\hline France & 6,269 & 1,024 & 370 & 137.7 & 5,899 & 886.7 & 13 & 24 & 62 & 0.68 & 2.54 & 2.53 \\
\hline Germany & 7,360 & 1,186 & 399 & 149.5 & 6,961 & $1,036.1$ & 13 & 24 & 63 & 0.71 & 2.53 & 2.48 \\
\hline Ireland & 2,846 & 595 & 156 & 87.9 & 2,690 & 507.4 & 15 & 24 & 62 & 0.63 & 2.48 & 2.49 \\
\hline Italy & 4,359 & 706 & 189 & 51 & 4,170 & 654.9 & 7 & 27 & 66 & 0.84 & 2.69 & 2.62 \\
\hline Liechtenstein & 60 & 1 & 8 & 0.0 & 52 & 1.3 & 0 & 31 & 69 & 1.61 & 2.59 & 2.54 \\
\hline Luxembourg & 7,485 & 1,048 & 355 & 125.2 & 7,130 & 922.6 & 12 & 24 & 64 & 0.77 & 2.58 & 2.43 \\
\hline Netherlands & 5,194 & 900 & 267 & 134.8 & 4,927 & 765.1 & 15 & 22 & 63 & 0.63 & 2.58 & 2.49 \\
\hline Norway & 3,324 & 482 & 40 & 7.6 & 3,284 & 474.7 & 2 & 31 & 68 & 0.70 & 2.55 & 2.59 \\
\hline Poland & 1,755 & 233 & 0 & 0.0 & 1,755 & 233.0 & 0 & 30 & 70 & & 2.84 & 2.64 \\
\hline Portugal & 3,390 & 440 & 90 & 7.5 & 3,300 & 432.6 & 2 & 30 & 68 & 1.45 & 2.71 & 2.70 \\
\hline Spain & 5,359 & 806 & 215 & 84.7 & 5,144 & 721.1 & 11 & 25 & 64 & 0.69 & 2.66 & 2.57 \\
\hline Sweden & 5,311 & 856 & 248 & 96.1 & 5,063 & 760.0 & 11 & 27 & 62 & 0.72 & 2.30 & 2.43 \\
\hline Switzerland & 6,809 & 1,106 & 387 & 170.9 & 6,422 & 934.6 & 15 & 21 & 63 & 0.78 & 2.55 & 2.46 \\
\hline United Kingdom & 6,924 & 1,307 & 329 & 161.8 & 6,595 & $1,145.5$ & 12 & 26 & 62 & 0.65 & 2.47 & 2.42 \\
\hline United States & 8,976 & 5,079 & 918 & $1,392.1$ & 8,058 & $3,686.6$ & 27 & 15 & 58 & 0.25 & 1.09 & 1.32 \\
\hline Asia Pacific & 8,675 & 2,103 & 220 & 520.6 & 8,455 & $1,582.5$ & 25 & 18 & 57 & 0.31 & 2.63 & 2.61 \\
\hline Other Regions & 542 & 163 & 3 & 0.1 & 539 & 163.1 & 0 & 25 & 75 & 1.36 & 2.64 & 2.80 \\
\hline Other Countries & 21,294 & 5,661 & 692 & $1,457.2$ & 20,602 & 4,203.3 & 26 & 22 & 52 & 0.28 & 2.34 & 2.49 \\
\hline Total & 123,922 & 26,620 & 5,571 & $4,836.8$ & 118,351 & $21,782.7$ & 18 & 22 & 60 & 0.40 & 2.33 & 2.30 \\
\hline
\end{tabular}


Table 2

Determinants of explicit and closet indexing at country level

This table presents estimates of yearly country-level regressions where the dependent variable is the percentage that explicitly indexed funds represent of the TNA in a country (Explicit indexing (\% TNA)), the TNA-weighted average total shareholder cost of explicitly indexed funds in a country (Explicit indexing (average TSC)), and the percentage that active funds with active share measure below 0.6 represent of the TNA in a country (Closet indexing (\% TNA)). The sample includes openend equity mutual funds taken from Lipper for which holdings are available in LionShares from 2002 to 2010 . In Panel A the unit of observation is a country of domicile $j$ in year $t$. In Panel B the unit of observation is a country of sale $k$ in year $t$. Regressions include year dummies. Refer to Appendix A for variable definitions. Robust $t$-statistics are reported in parentheses. *, **, *** reflects significance at the $10 \%, 5 \%$ and $1 \%$ levels.

\begin{tabular}{|c|c|c|c|c|c|c|}
\hline \multicolumn{7}{|c|}{ Panel A: By country of domicile } \\
\hline & \multicolumn{2}{|c|}{$\begin{array}{c}\text { Explicit indexing } \\
(\% \text { TNA) }\end{array}$} & \multicolumn{2}{|c|}{$\begin{array}{l}\text { Explicit indexing } \\
\text { (average TSC) }\end{array}$} & \multicolumn{2}{|c|}{$\begin{array}{c}\text { Closet indexing } \\
\text { (\% TNA) }\end{array}$} \\
\hline & $(1)$ & $(2)$ & (3) & $(4)$ & $(5)$ & $(6)$ \\
\hline \multirow[t]{2}{*}{ Approval } & $0.0575^{* *}$ & & 0.1174 & & -0.0099 & \\
\hline & $(2.51)$ & & $(1.54)$ & & $(-0.40)$ & \\
\hline \multirow[t]{2}{*}{ Judicial } & $0.0041^{* *}$ & & $-0.0245 * * *$ & & $-0.0063 * * *$ & \\
\hline & $(2.44)$ & & $(-4.27)$ & & $(-3.53)$ & \\
\hline \multirow[t]{2}{*}{ Fund industry size (log) } & & $0.0298 * * *$ & & $-0.0833 * * *$ & & $-0.0330 * * *$ \\
\hline & & (3.38) & & $(-2.77)$ & & $(-3.52)$ \\
\hline \multirow[t]{2}{*}{ Fund industry Herfindahl } & & $0.8183 * * *$ & & 0.1241 & & -0.0335 \\
\hline & & $(4.28)$ & & $(0.20)$ & & $(-0.16)$ \\
\hline \multirow[t]{2}{*}{ GDP per capita (log) } & & -0.0024 & & -0.0603 & & -0.0160 \\
\hline & & $(-0.17)$ & & $(-1.39)$ & & $(-1.09)$ \\
\hline Observations & 259 & 250 & 212 & 212 & 258 & 249 \\
\hline R-squared & 0.066 & 0.104 & 0.110 & 0.125 & 0.156 & 0.205 \\
\hline \multicolumn{7}{|l|}{ Panel B: By country of sale } \\
\hline & \multicolumn{2}{|c|}{$\begin{array}{c}\text { Explicit indexing } \\
\text { (\% TNA) }\end{array}$} & \multicolumn{2}{|c|}{$\begin{array}{l}\text { Explicit indexing } \\
\text { (average TSC) }\end{array}$} & \multicolumn{2}{|c|}{$\begin{array}{c}\text { Closet indexing } \\
(\% \text { TNA) }\end{array}$} \\
\hline & (1) & $(2)$ & (3) & (4) & (5) & (6) \\
\hline \multirow[t]{2}{*}{ Approval } & $0.1098 * * *$ & & -0.0223 & & -0.0009 & \\
\hline & (4.69) & & $(-0.38)$ & & $(-0.06)$ & \\
\hline \multirow[t]{2}{*}{ Judicial } & $0.0051^{* * *}$ & & $-0.0244^{* * *}$ & & $-0.0045 * * *$ & \\
\hline & (2.87) & & $(-5.21)$ & & $(-4.17)$ & \\
\hline \multirow[t]{2}{*}{ Fund industry size (log) } & & $0.0360 * * *$ & & $-0.0922 * * *$ & & $-0.0151^{* * *}$ \\
\hline & & (4.14) & & $(-4.50)$ & & $(-2.88)$ \\
\hline \multirow[t]{2}{*}{ Fund industry Herfindahl } & & $0.2874 * *$ & & 0.2181 & & $-0.2013^{* * *}$ \\
\hline & & $(2.49)$ & & $(0.63)$ & & $(-2.89)$ \\
\hline \multirow[t]{2}{*}{ GDP per capita (log) } & & -0.0037 & & $-0.1061^{* * *}$ & & -0.0123 \\
\hline & & $(-0.26)$ & & $(-3.26)$ & & $(-1.42)$ \\
\hline Observations & 254 & 254 & 240 & 240 & 254 & 254 \\
\hline R-squared & 0.124 & 0.089 & 0.137 & 0.265 & 0.156 & 0.167 \\
\hline
\end{tabular}


Table 3

Determinants of active management

This table presents estimates of panel regressions where the dependent variable is a fund's active share at year-end, defined as the percentage of a fund's portfolio holdings that differs from the fund's benchmark. The sample includes open-end active equity mutual funds taken from Lipper for which holdings are available in LionShares from 2002 to 2010. In columns (1) and (2) the unit of observation is a fund's primary share class $i$ domiciled in country $j$ in year $t$. In columns (3) and (4) the unit of observation is a fund share class $s$ offered for sale in country $k$ in year $t$. Regressions include year and benchmark dummies. Refer to Appendix A for variable definitions. Robust $t$-statistics clustered by country of domicile-year (columns (1) and (2)) or country of sale-year (columns (3) and (4)) are reported in parentheses. *, **, *** reflects significance at the $10 \%, 5 \%$ and $1 \%$ levels.

\begin{tabular}{|c|c|c|c|c|}
\hline & \multicolumn{2}{|c|}{ By country of domicile } & \multicolumn{2}{|c|}{ By country of sale } \\
\hline & $(1)$ & $(2)$ & (3) & $(4)$ \\
\hline Explicit indexing (\% TNA) & $\begin{array}{c}0.0075 \\
(0.47)\end{array}$ & & $\begin{array}{c}0.0171 * * \\
(2.38)\end{array}$ & \\
\hline Explicit indexing (average TSC) & & $\begin{array}{c}-0.0290 * * * \\
(-4.90)\end{array}$ & & $\begin{array}{c}-0.0128 * * * \\
(-4.33)\end{array}$ \\
\hline Tracking error & $\begin{array}{c}1.6678^{* * *} \\
(7.47)\end{array}$ & $\begin{array}{c}1.6470^{* * *} \\
(7.16)\end{array}$ & $\begin{array}{c}1.6039 * * * \\
(14.09)\end{array}$ & $\begin{array}{c}1.6056^{* * *} \\
(13.81)\end{array}$ \\
\hline Total shareholder cost & $\begin{array}{c}0.0266^{* * *} \\
(15.43)\end{array}$ & $\begin{array}{c}0.0285^{* * *} \\
(15.71)\end{array}$ & $\begin{array}{c}0.0153^{* * *} \\
(21.00)\end{array}$ & $\begin{array}{c}0.0153 * * * \\
(20.52)\end{array}$ \\
\hline Total net assets (log) & $\begin{array}{c}-0.0057 * * * \\
(-10.87)\end{array}$ & $\begin{array}{c}-0.0053^{* * *} \\
(-10.16)\end{array}$ & $\begin{array}{c}0.0003^{* *} \\
(2.37)\end{array}$ & $\begin{array}{c}0.0003^{* *} \\
(2.38)\end{array}$ \\
\hline Family total net assets (log) & $\begin{array}{c}-0.0039 * * * \\
(-5.06)\end{array}$ & $\begin{array}{c}-0.0044^{* * *} \\
(-5.55)\end{array}$ & $\begin{array}{c}-0.0067 * * * \\
(-18.84)\end{array}$ & $\begin{array}{c}-0.0068^{* * *} \\
(-18.90)\end{array}$ \\
\hline Fund age & $\begin{array}{c}-0.0008^{* * *} \\
(-5.55)\end{array}$ & $\begin{array}{c}-0.0008^{* * *} \\
(-5.38)\end{array}$ & $\begin{array}{c}-0.0010^{* * *} \\
(-8.93)\end{array}$ & $\begin{array}{c}-0.0010^{* * *} \\
(-8.87)\end{array}$ \\
\hline Flows & $\begin{array}{c}0.0079 * * * \\
\quad(6.69)\end{array}$ & $\begin{array}{c}0.0083^{* * *} \\
\quad(7.05)\end{array}$ & $\begin{array}{c}0.0003^{* * *} \\
\quad(8.19)\end{array}$ & $\begin{array}{c}0.0003^{* * *} \\
(8.22)\end{array}$ \\
\hline Benchmark-adjusted return & $\begin{array}{c}0.1414^{* * *} \\
\quad(5.87)\end{array}$ & $\begin{array}{c}0.1386^{* * *} \\
\quad(5.64)\end{array}$ & $\begin{array}{c}0.1645^{* * *} \\
(11.69)\end{array}$ & $\begin{array}{c}0.1643^{* * *} \\
(11.52)\end{array}$ \\
\hline International fund dummy & $\begin{array}{c}-0.0201 * * * \\
(-4.02)\end{array}$ & $\begin{array}{c}-0.0166^{* * *} \\
(-3.18)\end{array}$ & $\begin{array}{c}-0.0354^{* * *} \\
(-5.18)\end{array}$ & $\begin{array}{c}-0.0349 * * * \\
(-5.20)\end{array}$ \\
\hline Fund of fund dummy & $\begin{array}{c}0.0399 * * * \\
(4.58)\end{array}$ & $\begin{array}{c}0.0451^{* * *} \\
\quad(5.01)\end{array}$ & $\begin{array}{c}0.0409^{* * *} \\
\quad(7.97)\end{array}$ & $\begin{array}{c}0.0412 * * * \\
\quad(8.02)\end{array}$ \\
\hline Off-shore fund dummy & $\begin{array}{c}0.0342 * * * \\
\quad(2.86)\end{array}$ & $\begin{array}{c}0.0620^{* * *} \\
\quad(4.26)\end{array}$ & $\begin{array}{c}0.0120^{* * *} \\
\quad(6.31)\end{array}$ & $\begin{array}{c}0.0120^{* * *} \\
\quad(6.35)\end{array}$ \\
\hline Approval & $\begin{array}{c}0.0087^{* *} \\
(1.98)\end{array}$ & $\begin{array}{c}0.0151^{* * *} \\
\quad(3.14)\end{array}$ & $\begin{array}{c}-0.0025^{* *} \\
(-2.05)\end{array}$ & $\begin{array}{c}-0.0026 * * \\
(-2.08)\end{array}$ \\
\hline Judicial & $\begin{array}{c}0.0026^{* * *} \\
(4.70)\end{array}$ & $\begin{array}{c}0.0024 * * * \\
(3.92)\end{array}$ & $\begin{array}{c}0.0006^{* * *} \\
(4.89)\end{array}$ & $\begin{array}{c}0.0004^{* *} \\
(2.48)\end{array}$ \\
\hline Fund industry size (log) & $\begin{array}{c}0.0081^{* * *} \\
(5.20)\end{array}$ & $\begin{array}{c}0.0046^{* *} \\
(2.50)\end{array}$ & $\begin{array}{c}0.0024 * * * \\
(3.74)\end{array}$ & $\begin{array}{c}0.0020^{* * *} \\
(3.23)\end{array}$ \\
\hline Fund industry Herfindahl & $\begin{array}{c}-0.2466 * * * \\
(-6.31)\end{array}$ & $\begin{array}{c}-0.2122 * * * \\
(-6.00)\end{array}$ & $\begin{array}{r}-0.0030 \\
(-0.36)\end{array}$ & $\begin{array}{c}0.0106 \\
(0.96)\end{array}$ \\
\hline GDP per capita (log) & $\begin{array}{c}-0.0352^{* * *} \\
(-7.80)\end{array}$ & $\begin{array}{c}-0.0388 * * * \\
(-8.56)\end{array}$ & $\begin{array}{c}-0.0152^{* * *} \\
(-7.10)\end{array}$ & $\begin{array}{c}-0.0165 * * * \\
(-6.73)\end{array}$ \\
\hline Observations & 58,487 & 56,554 & 423,103 & 415,797 \\
\hline R-squared & 0.622 & 0.623 & 0.617 & 0.616 \\
\hline
\end{tabular}




\section{Table 4}

Fund flows and active management

This table presents estimates of panel regressions where the dependent variable is a fund's yearly net flows, defined as new external money growth as percentage of TNA. Return rank is equal to zero for funds in the bottom $20 \%$ of performance (benchmark-adjusted return or four-factor alpha over the prior 12 months), one for funds in the middle $60 \%$, and two for funds in the top 20\%. The sample includes open-end active equity mutual funds taken from Lipper for which holdings are available in LionShares from 2002 to 2010. In columns (1)-(2) the unit of observation is a fund's primary share class $i$ domiciled in country $j$ in year $t$. In columns (3)-(4) the unit of observation is a fund share class $s$ offered for sale in country $k$ in year $t$. Regressions include year and benchmark dummies. Refer to Appendix A for variable definitions. Robust $t$-statistics clustered by country of domicile-year (columns (1)-(2)) or country of sale-year (columns (3)-(4)) are reported in parentheses. *, **, *** reflects significance at the $10 \%, 5 \%$ and $1 \%$ levels.

\begin{tabular}{|c|c|c|c|c|}
\hline \multirow{3}{*}{ Return rank based on: } & \multicolumn{2}{|c|}{ By country of domicile } & \multicolumn{2}{|c|}{ By country of sale } \\
\hline & $\begin{array}{c}\text { Benchmark-adjusted } \\
\text { return }\end{array}$ & $\begin{array}{l}\text { Benchmark-adjusted } \\
\text { four-factor alpha }\end{array}$ & $\begin{array}{c}\text { Benchmark-adjusted } \\
\text { return }\end{array}$ & $\begin{array}{c}\text { Benchmark-adjusted } \\
\text { four-factor alpha }\end{array}$ \\
\hline & $(1)$ & $(2)$ & (3) & $(4)$ \\
\hline \multirow[t]{2}{*}{ Active share } & $0.0865^{*}$ & $0.1218^{* * *}$ & $0.3782 * * *$ & $0.3648 * * *$ \\
\hline & (1.89) & $(2.82)$ & (11.91) & (11.95) \\
\hline \multirow[t]{2}{*}{ Return rank } & 0.0250 & 0.0224 & $0.0695 * * *$ & $0.0211^{* *}$ \\
\hline & $(1.20)$ & $(1.23)$ & (4.91) & (1.97) \\
\hline \multirow[t]{2}{*}{ Active share $\times$ Return rank } & $0.1408 * * *$ & $0.1166^{* * *}$ & $0.1349 * * *$ & $0.1500 * * *$ \\
\hline & (4.17) & $(4.21)$ & (6.68) & $(8.76)$ \\
\hline \multirow[t]{2}{*}{ Tracking error } & 0.1573 & $0.1462 *$ & $0.6609 * * *$ & $0.5904 * * *$ \\
\hline & $(1.55)$ & $(1.70)$ & $(4.67)$ & $(4.85)$ \\
\hline \multirow[t]{2}{*}{ Total shareholder cost } & $-0.0256 * * *$ & $-0.0254 * * *$ & $-0.0506 * * *$ & $-0.0520 * * *$ \\
\hline & $(-4.07)$ & $(-3.97)$ & $(-10.33)$ & $(-9.93)$ \\
\hline \multirow{2}{*}{ Total net assets (log) } & $-0.0804^{* * *}$ & $-0.0764^{* * *}$ & $-0.1199 * * *$ & $-0.1146 * * *$ \\
\hline & $(-14.54)$ & $(-14.38)$ & $(-23.95)$ & $(-23.68)$ \\
\hline \multirow[t]{2}{*}{ Family total net assets (log) } & $0.0250 * * *$ & $0.0238^{* * *}$ & $0.0597 * * *$ & $0.0581^{* * *}$ \\
\hline & (6.69) & $(6.27)$ & $(15.16)$ & $(14.80)$ \\
\hline \multirow[t]{2}{*}{ Fund age } & $-0.0030 * * *$ & $-0.0024 * * *$ & $-0.0056 * * *$ & $-0.0032 * * *$ \\
\hline & $(-7.78)$ & $(-6.03)$ & $(-15.03)$ & $(-9.44)$ \\
\hline \multirow[t]{2}{*}{ International fund dummy } & 0.0176 & 0.0203 & $0.0573 * * *$ & $0.0675 * * *$ \\
\hline & $(0.84)$ & $(0.95)$ & $(2.70)$ & (3.13) \\
\hline \multirow[t]{2}{*}{ Fund of fund dummy } & $-0.0749 * * *$ & $-0.0677 * * *$ & $-0.0953 * * *$ & $-0.0891 * * *$ \\
\hline & $(-3.00)$ & $(-2.67)$ & $(-4.52)$ & $(-4.10)$ \\
\hline \multirow[t]{2}{*}{ Off shore fund dummy } & $-0.2038 * * *$ & $-0.1963 * * *$ & 0.0096 & 0.0006 \\
\hline & $(-3.55)$ & $(-3.37)$ & (1.19) & $(0.07)$ \\
\hline \multirow[t]{2}{*}{ Approval } & -0.0235 & -0.0193 & 0.0004 & 0.0015 \\
\hline & $(-1.24)$ & $(-1.01)$ & $(0.08)$ & $(0.30)$ \\
\hline \multirow[t]{2}{*}{ Judicial } & $-0.0091^{* * *}$ & $-0.0088 * * *$ & 0.0001 & -0.0000 \\
\hline & $(-3.14)$ & $(-2.99)$ & $(0.18)$ & $(-0.09)$ \\
\hline \multirow[t]{2}{*}{ Fund industry size (log) } & $0.0167 * *$ & $0.0164 * *$ & $-0.0109 * * *$ & $-0.0102 * * *$ \\
\hline & $(2.05)$ & (1.98) & $(-4.02)$ & $(-3.77)$ \\
\hline \multirow[t]{2}{*}{ Fund industry Herfindahl } & -0.0585 & -0.0564 & -0.0177 & -0.0026 \\
\hline & $(-0.33)$ & $(-0.31)$ & $(-0.41)$ & $(-0.06)$ \\
\hline \multirow[t]{2}{*}{ GDP per capita (log) } & $0.1166 * * *$ & $0.1131 * * *$ & $0.0279 * * *$ & $0.0263 * *$ \\
\hline & (5.05) & $(4.82)$ & (2.61) & $(2.55)$ \\
\hline Observations & 52,767 & 52,767 & 375,494 & 375,494 \\
\hline R-squared & 0.083 & 0.079 & 0.099 & 0.093 \\
\hline
\end{tabular}


Table 5

Determinants of the total shareholder costs of active funds

This table presents estimates of panel regressions where the dependent variable is a fund's yearly total shareholder cost, defined as total expense ratio plus one-fifth of the front-end load. The sample includes open-end active equity mutual funds taken from Lipper for which holdings are available in LionShares from 2002 to 2010. In columns (1)-(3) the unit of observation is a fund's primary share class $i$ domiciled in country $j$ in year $t$. In columns (4)-(6) the unit of observation is a fund share class $s$ offered for sale in country $k$ in year $t$. Regressions include year and benchmark dummies. Refer to Appendix A for variable definitions. Robust $t$-statistics clustered by country of domicile-year (columns (1)-(3)) or country of sale-year (columns (4)-(6)) are reported in parentheses. *,**, *** reflects significance at the $10 \%, 5 \%$ and $1 \%$ levels.

\begin{tabular}{|c|c|c|c|c|c|c|}
\hline & \multicolumn{3}{|c|}{ By country of domicile } & \multicolumn{3}{|c|}{ By country of sale } \\
\hline & $(1)$ & $(2)$ & (3) & (4) & (5) & (6) \\
\hline Explicit indexing (\% TNA) & $\begin{array}{c}-0.0444 \\
(-0.36)\end{array}$ & & & $\begin{array}{c}-0.4118 * * * \\
(-4.18)\end{array}$ & & \\
\hline Explicit indexing (average TSC) & & $\begin{array}{c}0.3275^{* * *} \\
(7.44)\end{array}$ & & & $\begin{array}{c}0.1239 * * * \\
(5.84)\end{array}$ & \\
\hline Closet indexing (\% TNA) & & & $\begin{array}{c}0.2863^{* *} \\
(2.44)\end{array}$ & & & $\begin{array}{c}0.3035^{* *} \\
(2.29)\end{array}$ \\
\hline Active share & $\begin{array}{c}0.6080^{* * *} \\
(13.96)\end{array}$ & $\begin{array}{c}0.6382 * * * \\
(14.29)\end{array}$ & $\begin{array}{c}0.6192 * * * \\
(13.93)\end{array}$ & $\begin{array}{c}0.5867 * * * \\
(23.96)\end{array}$ & $\begin{array}{c}0.5857 * * * \\
(23.56)\end{array}$ & $\begin{array}{c}0.5892 * * * \\
(23.57)\end{array}$ \\
\hline Tracking error & $\begin{array}{c}0.9326^{* * *} \\
\quad(6.31)\end{array}$ & $\begin{array}{l}1.0024 * * * \\
(6.61)\end{array}$ & $\begin{array}{c}0.9722^{* * * *} \\
\quad(6.59)\end{array}$ & $\begin{array}{c}1.3308^{* * * *} \\
(9.87)\end{array}$ & $\begin{array}{c}1.3261^{* * * *} \\
(10.07)\end{array}$ & $\begin{array}{c}1.3402 * * * \\
(10.35)\end{array}$ \\
\hline Total net assets (log) & $\begin{array}{c}-0.0719 * * * \\
(-20.27)\end{array}$ & $\begin{array}{c}-0.0752 * * * \\
(-22.74)\end{array}$ & $\begin{array}{c}-0.0718 * * * \\
(-20.53)\end{array}$ & $\begin{array}{c}-0.0324 * * * \\
(-18.01)\end{array}$ & $\begin{array}{c}-0.0327 * * * \\
(-17.83)\end{array}$ & $\begin{array}{c}-0.0325^{* * *} \\
(-17.78)\end{array}$ \\
\hline Family total net assets (log) & $\begin{array}{c}0.0146^{* * *} \\
(2.82)\end{array}$ & $\begin{array}{c}0.0176^{* * * *} \\
(3.40)\end{array}$ & $\begin{array}{c}0.0146^{* * *} \\
(2.87)\end{array}$ & $\begin{array}{c}-0.0106 * * * \\
(-5.06)\end{array}$ & $\begin{array}{c}-0.0098 * * * \\
(-4.62)\end{array}$ & $\begin{array}{c}-0.0096 * * * \\
(-4.64)\end{array}$ \\
\hline Fund age & $\begin{array}{c}0.0058^{* * *} \\
(6.89)\end{array}$ & $\begin{array}{c}0.0052^{* * *} \\
\quad(6.30)\end{array}$ & $\begin{array}{c}0.0057 * * * \\
\quad(6.80)\end{array}$ & $\begin{array}{c}0.0131^{* * *} \\
(13.18)\end{array}$ & $\begin{array}{c}0.0130 * * * \\
(12.99)\end{array}$ & $\begin{array}{c}0.0131 * * * \\
(13.02)\end{array}$ \\
\hline Flows & $\begin{array}{c}0.0055 \\
(0.90)\end{array}$ & $\begin{array}{c}0.0032 \\
(0.52)\end{array}$ & $\begin{array}{c}0.0044 \\
(0.72)\end{array}$ & $\begin{array}{c}-0.0019 * * * \\
(-6.59)\end{array}$ & $\begin{array}{c}-0.0019 * * * \\
(-6.51)\end{array}$ & $\begin{array}{c}-0.0019 * * * \\
(-6.51)\end{array}$ \\
\hline Benchmark-adjusted return & $\begin{array}{c}-0.2542 * * * \\
(-4.04)\end{array}$ & $\begin{array}{c}-0.2173 * * * \\
(-3.55)\end{array}$ & $\begin{array}{c}-0.2480 * * * \\
(-3.97)\end{array}$ & $\begin{array}{c}-0.5942 * * * \\
(-14.02)\end{array}$ & $\begin{array}{c}-0.5896 * * * \\
(-13.87)\end{array}$ & $\begin{array}{c}-0.5969 * * * \\
(-14.09)\end{array}$ \\
\hline International fund dummy & $\begin{array}{c}0.3634^{* * * *} \\
(14.99)\end{array}$ & $\begin{array}{c}0.2973^{* * * *} \\
(10.13)\end{array}$ & $\begin{array}{c}0.3359 * * * \\
(13.60)\end{array}$ & $\begin{array}{c}0.5105^{* * * *} \\
(17.25)\end{array}$ & $\begin{array}{c}0.5256^{* * * *} \\
(19.34)\end{array}$ & $\begin{array}{c}0.5258 * * * \\
(16.68)\end{array}$ \\
\hline Fund of fund dummy & $\begin{array}{c}-0.2490 * * * \\
(-6.90)\end{array}$ & $\begin{array}{c}-0.2402 * * * \\
(-6.78)\end{array}$ & $\begin{array}{c}-0.2546 * * * \\
(-7.04)\end{array}$ & $\begin{array}{c}-0.3911 * * * \\
(-13.99)\end{array}$ & $\begin{array}{c}-0.3934 * * * \\
(-13.89)\end{array}$ & $\begin{array}{c}-0.3912 * * * \\
(-13.98)\end{array}$ \\
\hline Off-shore fund dummy & $\begin{array}{c}-0.0404 \\
(-0.43)\end{array}$ & $\begin{array}{c}-0.3208 * * * \\
(-3.09)\end{array}$ & $\begin{array}{c}-0.0319 \\
(-0.36)\end{array}$ & $\begin{array}{c}0.2604^{* * * *} \\
(22.04)\end{array}$ & $\begin{array}{c}0.2611^{* * * *} \\
(21.67)\end{array}$ & $\begin{array}{c}0.2620 * * * \\
(22.07)\end{array}$ \\
\hline Approval & $\begin{array}{c}-0.3734 * * * \\
(-8.55)\end{array}$ & $\begin{array}{c}-0.4667 * * * \\
(-11.81)\end{array}$ & $\begin{array}{c}-0.3727 * * * \\
(-8.63)\end{array}$ & $\begin{array}{c}-0.0010 \\
(-0.11)\end{array}$ & $\begin{array}{c}-0.0046 \\
(-0.51)\end{array}$ & $\begin{array}{c}-0.0056 \\
(-0.61)\end{array}$ \\
\hline Judicial & $\begin{array}{c}-0.0088 \\
(-1.59)\end{array}$ & $\begin{array}{r}-0.0037 \\
(-0.68)\end{array}$ & $\begin{array}{c}-0.0082 \\
(-1.50)\end{array}$ & $\begin{array}{c}-0.0010 \\
(-1.16)\end{array}$ & $\begin{array}{c}0.0006 \\
(0.49)\end{array}$ & $\begin{array}{c}-0.0016^{* *} \\
(-2.05)\end{array}$ \\
\hline Fund industry size (log) & $\begin{array}{c}-0.0537 * * * \\
(-3.39)\end{array}$ & $\begin{array}{c}0.0027 \\
(0.16)\end{array}$ & $\begin{array}{c}-0.0494 * * * \\
(-2.96)\end{array}$ & $\begin{array}{c}-0.0270 * * * \\
(-5.59)\end{array}$ & $\begin{array}{c}-0.0254 * * * \\
(-5.29)\end{array}$ & $\begin{array}{c}-0.0297 * * * \\
(-6.05)\end{array}$ \\
\hline Fund industry Herfindahl & $\begin{array}{c}-1.5938 * * * \\
(-4.27)\end{array}$ & $\begin{array}{c}-1.6571 * * * \\
(-4.27)\end{array}$ & $\begin{array}{c}-1.6930 * * * \\
(-4.58)\end{array}$ & $\begin{array}{c}-0.0375 \\
(-0.40)\end{array}$ & $\begin{array}{c}-0.1661 \\
(-1.18)\end{array}$ & $\begin{array}{c}0.0310 \\
(0.32)\end{array}$ \\
\hline GDP per capita (log) & $\begin{array}{c}0.0962^{* *} \\
(2.24)\end{array}$ & $\begin{array}{c}0.1348^{* * *} \\
(3.14)\end{array}$ & $\begin{array}{c}0.1140^{* * *} \\
(2.73)\end{array}$ & $\begin{array}{c}0.0500^{* * *} \\
(2.80)\end{array}$ & $\begin{array}{c}0.0549 * * * \\
(2.65)\end{array}$ & $\begin{array}{c}0.0469 * * * \\
(2.61)\end{array}$ \\
\hline Observations & 58,487 & 56,554 & 58,487 & 423,103 & 415,797 & 423,103 \\
\hline R-squared & 0.390 & 0.393 & 0.391 & 0.198 & 0.199 & 0.198 \\
\hline
\end{tabular}




\section{Table 6}

Differences-in-differences estimates using the Passage of Pension Acts

This table presents differences-in-differences estimates where the dependent variable is the fund's active share at year-end (columns (1)-(3)), yearly total shareholder cost (columns (4)-(6)), and the fund industry Herfindahl at year-end (column (7)). Active share is the percentage of a fund's portfolio holdings that differs from the fund's benchmark. Total shareholder cost is total expense ratio plus one-fifth of the front-end load. The sample includes open-end active equity mutual funds taken from Lipper for which holdings are available in LionShares from 2002 to 2010. In Panel A the unit of observation is a fund's primary share class $i$ domiciled in country $j$ in year $t$. In Panel B the unit of observation is a fund share class $s$ offered for sale in country $k$ in year $t$. Post pension act (year $>=0$ ) is a dummy variable that equals one if a fund's country has passed a pension act that year or earlier. Pre pension act (year -3) is a dummy variable that equals one if a fund's country will pass a pension act in three years, two years or one year. Post pension act (year 0) is a dummy variable that equals one if a fund's country passes a pension act in the current year. Post pension act (year $1+$ ) is a dummy variable that equals one if a fund's country passed a pension act one year ago. Post pension act (year 2+) is a dummy variable that equals one if a fund's country passed a pension act two years ago or more. Regressions include year and fund fixed effects. Refer to Appendix A for variable definitions. Robust $t$-statistics clustered by country of domicile-year (Panel A) or country of sale-year (Panel B) are reported in parentheses. *, **, *** reflects significance at the $10 \%, 5 \%$ and $1 \%$ levels.

\begin{tabular}{|c|c|c|c|c|c|c|c|}
\hline \multicolumn{8}{|l|}{ Panel A: By country of domicile } \\
\hline & \multicolumn{3}{|c|}{ Active share } & \multicolumn{3}{|c|}{ Total shareholder cost } & \multirow{2}{*}{$\begin{array}{c}\text { Fund industry } \\
\text { Herfindahl } \\
(7)\end{array}$} \\
\hline & $(1)$ & $(2)$ & (3) & $(4)$ & $(5)$ & (6) & \\
\hline Post pension act (year $>=0$ ) & $\begin{array}{c}0.0132 * \\
(1.83)\end{array}$ & $\begin{array}{c}0.0122 * \\
(1.86)\end{array}$ & & $\begin{array}{c}-0.0519 * * \\
(-1.98)\end{array}$ & $\begin{array}{c}-0.0361^{* *} \\
(-2.09)\end{array}$ & & \\
\hline Pre pension act $(-3<=$ year $<=-1)$ & & & $\begin{array}{c}0.0143 \\
(1.22)\end{array}$ & & & $\begin{array}{c}-0.0272 \\
(-1.12)\end{array}$ & $\begin{array}{c}-0.0193 \\
(-1.35)\end{array}$ \\
\hline Post pension act (year 0) & & & $\begin{array}{c}0.0241^{* * *} \\
(2.79)\end{array}$ & & & $\begin{array}{c}-0.0484 * * \\
(-2.06)\end{array}$ & $\begin{array}{c}-0.0172 \\
(-1.14)\end{array}$ \\
\hline Post pension act (year 1) & & & $\begin{array}{c}0.0258^{* * *} \\
(3.10)\end{array}$ & & & $\begin{array}{c}-0.0623^{* *} \\
(-2.48)\end{array}$ & $\begin{array}{c}-0.0152 \\
(-0.96)\end{array}$ \\
\hline Post pension act (year $>=2$ ) & & & $\begin{array}{c}0.0305 * * * \\
(3.38)\end{array}$ & & & $\begin{array}{c}-0.0692 * * * \\
(-2.74)\end{array}$ & $\begin{array}{c}-0.0096 \\
(-0.58)\end{array}$ \\
\hline Total net assets (log) & & $\begin{array}{c}-0.0128 * * * \\
(-6.55)\end{array}$ & $\begin{array}{c}-0.0128 * * * \\
(-6.53)\end{array}$ & & $\begin{array}{c}-0.0374 * * * \\
(-6.48)\end{array}$ & $\begin{array}{c}-0.0374 * * * \\
(-6.45)\end{array}$ & $\begin{array}{c}0.0018^{* * * *} \\
(2.64)\end{array}$ \\
\hline Family total net assets (log) & & $\begin{array}{c}-0.0004 \\
(-0.14)\end{array}$ & $\begin{array}{c}-0.0011 \\
(-0.38)\end{array}$ & & $\begin{array}{c}-0.0235^{* *} \\
(-2.37)\end{array}$ & $\begin{array}{c}-0.0224 * * \\
(-2.22)\end{array}$ & $\begin{array}{c}-0.0038 * * \\
(-2.09)\end{array}$ \\
\hline Fund age & & $\begin{array}{c}0.0080^{* * *} \\
(7.70)\end{array}$ & $\begin{array}{c}0.0074 * * * \\
(6.56)\end{array}$ & & $\begin{array}{c}0.0149 * * * \\
(5.42)\end{array}$ & $\begin{array}{c}0.0150 * * * \\
(4.67)\end{array}$ & $\begin{array}{c}-0.0028^{* *} \\
(-2.31)\end{array}$ \\
\hline Flows & & $\begin{array}{c}0.0063^{* * *} \\
(4.95)\end{array}$ & $\begin{array}{c}0.0062 * * * \\
\quad(4.84)\end{array}$ & & $\begin{array}{c}0.0178^{* * *} \\
\quad(3.92)\end{array}$ & $\begin{array}{c}0.0178^{* * *} \\
\quad(3.87)\end{array}$ & $\begin{array}{c}-0.0002 \\
(-0.72)\end{array}$ \\
\hline Observations & 30,116 & 26,638 & 26,638 & 30,101 & 26,630 & 26,630 & 26,638 \\
\hline R-squared & 0.906 & 0.909 & 0.909 & 0.939 & 0.946 & 0.946 & 0.973 \\
\hline
\end{tabular}


Table 6 (continued)

\begin{tabular}{|c|c|c|c|c|c|c|c|}
\hline \multicolumn{8}{|l|}{ Panel B: By country of sale } \\
\hline & \multicolumn{3}{|c|}{ Active share } & \multicolumn{3}{|c|}{ Total shareholder cost } & \multirow{2}{*}{$\begin{array}{c}\text { Fund industry } \\
\text { Herfindahl } \\
(7)\end{array}$} \\
\hline & $(1)$ & $(2)$ & $(3)$ & $(4)$ & $(5)$ & $(6)$ & \\
\hline Post pension act & $\begin{array}{c}0.0197 * * * \\
(4.09)\end{array}$ & $\begin{array}{c}0.0154 * * * \\
(4.13)\end{array}$ & & $\begin{array}{c}-0.0471 * * \\
(-2.50)\end{array}$ & $\begin{array}{c}-0.0311 * * \\
(-2.09)\end{array}$ & & \\
\hline Pre pension act $(-3<=$ year $<=-1)$ & & & $\begin{array}{c}0.0159 \\
(1.08)\end{array}$ & & & $\begin{array}{c}-0.0201 \\
(-1.25)\end{array}$ & $\begin{array}{c}-0.0158 \\
(-1.42)\end{array}$ \\
\hline Pension act (year 0) & & & $\begin{array}{c}0.0392 * * * \\
\quad(5.56)\end{array}$ & & & $\begin{array}{c}-0.1131 * * * \\
(-5.90)\end{array}$ & $\begin{array}{c}-0.0167 \\
(-1.26)\end{array}$ \\
\hline Post pension act (year 1) & & & $\begin{array}{c}0.0411^{* * *} \\
\quad(5.66)\end{array}$ & & & $\begin{array}{c}-0.1209 * * * \\
(-6.26)\end{array}$ & $\begin{array}{c}-0.0201 \\
(-1.51)\end{array}$ \\
\hline Post pension act (year >=2) & & & $\begin{array}{c}0.0449 * * * \\
(5.83)\end{array}$ & & & $\begin{array}{c}-0.0951^{* * * *} \\
(-4.26)\end{array}$ & $\begin{array}{c}-0.0162 \\
(-1.19)\end{array}$ \\
\hline Total net assets (log) & & $\begin{array}{c}-0.0137 * * * \\
(-8.54)\end{array}$ & $\begin{array}{c}-0.0136^{* * *} \\
(-8.48)\end{array}$ & & $\begin{array}{c}-0.0316 * * * \\
(-6.60)\end{array}$ & $\begin{array}{c}-0.0316^{* * *} \\
(-6.53)\end{array}$ & $\begin{array}{l}-0.0003 \\
(-0.29)\end{array}$ \\
\hline Family total net assets (log) & & $\begin{array}{c}0.0002 \\
(0.08)\end{array}$ & $\begin{array}{c}-0.0011 \\
(-0.53)\end{array}$ & & $\begin{array}{c}-0.0311^{* * *} \\
(-5.04)\end{array}$ & $\begin{array}{c}-0.0275^{* * *} \\
(-4.30)\end{array}$ & $\begin{array}{c}0.0005 \\
(0.15)\end{array}$ \\
\hline Fund age & & $\begin{array}{c}0.0075^{* * * *} \\
(10.91)\end{array}$ & $\begin{array}{c}0.0069 * * * \\
(8.67)\end{array}$ & & $\begin{array}{c}0.0196 * * * \\
(7.86)\end{array}$ & $\begin{array}{l}0.0189 * * * \\
\quad(6.61)\end{array}$ & $\begin{array}{c}-0.0025 \\
(-1.23)\end{array}$ \\
\hline Flows & & $\begin{array}{l}0.0071^{* * *} \\
\quad(9.38)\end{array}$ & $\begin{array}{c}0.0069 * * * \\
(9.10)\end{array}$ & & $\begin{array}{c}0.0198 * * * \\
(7.32)\end{array}$ & $\begin{array}{c}0.0195 * * * \\
\quad(6.97)\end{array}$ & $\begin{array}{c}-0.0004 \\
(-0.56)\end{array}$ \\
\hline Observations & 62,155 & 56,320 & 56,320 & 62,132 & 56,306 & 56,306 & 56,320 \\
\hline R-squared & 0.911 & 0.915 & 0.915 & 0.938 & 0.945 & 0.945 & 0.490 \\
\hline
\end{tabular}


Table 7

Determinants of the Performance of Active Funds

This table presents estimates of panel regressions where the dependent variable is a fund's yearly benchmark-adjusted return four-factor alpha. Benchmark-adjusted return is the difference between the fund net return and its benchmark return. Four-factor alphas are estimated using three years of past monthly benchmark-adjusted fund returns in U.S. dollars with regional factors (Asia, Europe, North America or Emerging Markets) or world factors in the case of world funds. The sample includes open-end active equity mutual funds taken from Lipper for which holdings are available in LionShares from 2002 to 2010 . In Panel A the unit of observation is a fund's primary share class $i$ domiciled in country $j$ in year $t$. In Panel B the unit of observation is a fund share class $s$ offered for sale in country $k$ in year $t$. All explanatory variables are lagged by one period. Regressions include year and benchmark dummies. Refer to Appendix A for variable definitions. Robust $t$-statistics clustered by country of domicile-year (Panel A) or country of sale-year (Panel B) are reported in parentheses. *, **, *** reflects significance at the 10\%, 5\% and 1\% levels.

\begin{tabular}{|c|c|c|c|c|}
\hline \multicolumn{5}{|l|}{ Panel A: By country of domicile } \\
\hline & $(1)$ & $(2)$ & $(3)$ & $(4)$ \\
\hline Active share & $\begin{array}{c}0.0319 * * * \\
(6.19)\end{array}$ & $\begin{array}{c}0.0362^{* * *} \\
(5.29)\end{array}$ & $\begin{array}{c}0.0171^{*} \\
(1.73)\end{array}$ & $\begin{array}{c}0.0230^{* *} \\
(1.98)\end{array}$ \\
\hline Explicit indexing (\% TNA) & & $\begin{array}{l}0.0106 \\
(0.43)\end{array}$ & & \\
\hline Active share $\times$ Explicit indexing $(\%$ TNA) & & $\begin{array}{c}-0.0351 \\
(-0.95)\end{array}$ & & \\
\hline Explicit indexing (average TSC) & & & $\begin{array}{c}-0.0166^{* *} \\
(-2.34)\end{array}$ & \\
\hline Active share $\times$ Explicit indexing (average TSC) & & & $\begin{array}{c}0.0163^{*} \\
(1.75)\end{array}$ & \\
\hline Closet indexing (\% TNA) & & & & $\begin{array}{c}-0.0105 \\
(-0.41)\end{array}$ \\
\hline Active share $\times$ Closet indexing $(\%$ TNA) & & & & $\begin{array}{c}0.0255 \\
(0.75)\end{array}$ \\
\hline Tracking error & $\begin{array}{c}-0.0792 * * * \\
(-3.28)\end{array}$ & $\begin{array}{c}-0.0793 * * * \\
(-3.31)\end{array}$ & $\begin{array}{c}-0.0807 * * * \\
(-3.27)\end{array}$ & $\begin{array}{c}-0.0781^{* * * *} \\
(-3.22)\end{array}$ \\
\hline Total shareholder cost & $\begin{array}{c}-0.0037 * * * \\
(-4.60)\end{array}$ & $\begin{array}{c}-0.0037 * * * \\
(-4.63)\end{array}$ & $\begin{array}{c}-0.0033 * * * \\
(-4.09)\end{array}$ & $\begin{array}{c}-0.0037 * * * \\
(-4.70)\end{array}$ \\
\hline Total net assets (log) & $\begin{array}{c}-0.0011 * * * \\
(-2.62)\end{array}$ & $\begin{array}{c}-0.0011 * * * \\
(-2.74)\end{array}$ & $\begin{array}{c}-0.0011^{* *} \\
(-2.55)\end{array}$ & $\begin{array}{c}-0.0011^{* * * *} \\
(-2.61)\end{array}$ \\
\hline Family total net assets (log) & $\begin{array}{c}0.0016^{* * * *} \\
(5.53)\end{array}$ & $\begin{array}{c}0.0016 * * * \\
(5.38)\end{array}$ & $\begin{array}{c}0.0016^{* * * *} \\
(5.26)\end{array}$ & $\begin{array}{c}0.0016^{* * *} \\
(5.55)\end{array}$ \\
\hline Fund age & $\begin{array}{c}-0.0000 \\
(-0.26)\end{array}$ & $\begin{array}{c}-0.0000 \\
(-0.29)\end{array}$ & $\begin{array}{c}-0.0000 \\
(-0.31)\end{array}$ & $\begin{array}{c}-0.0000 \\
(-0.30)\end{array}$ \\
\hline Flows & $\begin{array}{c}0.0022^{* * *} \\
(2.63)\end{array}$ & $\begin{array}{c}0.0021^{* *} \\
(2.56)\end{array}$ & $\begin{array}{c}0.0020^{* *} \\
(2.39)\end{array}$ & $\begin{array}{c}0.0022^{* * *} \\
(2.61)\end{array}$ \\
\hline International fund dummy & $\begin{array}{c}-0.0038 \\
(-0.80)\end{array}$ & $\begin{array}{c}-0.0045 \\
(-0.95)\end{array}$ & $\begin{array}{c}-0.0027 \\
(-0.56)\end{array}$ & $\begin{array}{c}-0.0047 \\
(-1.02)\end{array}$ \\
\hline Fund of fund dummy & $\begin{array}{c}-0.0116 * * * \\
(-2.69)\end{array}$ & $\begin{array}{c}-0.0118 * * * \\
(-2.72)\end{array}$ & $\begin{array}{c}-0.0120 * * * \\
(-2.64)\end{array}$ & $\begin{array}{c}-0.0118^{* * * *} \\
(-2.74)\end{array}$ \\
\hline Off-shore fund dummy & $\begin{array}{c}0.0019 \\
(0.35)\end{array}$ & $\begin{array}{c}-0.0022 \\
(-0.30)\end{array}$ & $\begin{array}{c}0.0080 \\
(1.07)\end{array}$ & $\begin{array}{l}0.0016 \\
(0.29)\end{array}$ \\
\hline Approval & $\begin{array}{c}-0.0047 \\
(-1.43)\end{array}$ & $\begin{array}{c}-0.0042 \\
(-1.28)\end{array}$ & $\begin{array}{c}-0.0035 \\
(-0.95)\end{array}$ & $\begin{array}{c}-0.0045 \\
(-1.36)\end{array}$ \\
\hline Judicial & $\begin{array}{c}0.0006^{* *} \\
(2.33)\end{array}$ & $\begin{array}{l}0.0005 \\
(1.53)\end{array}$ & $\begin{array}{c}0.0007 * * \\
(2.47)\end{array}$ & $\begin{array}{c}0.0006^{* *} \\
(2.32)\end{array}$ \\
\hline Fund industry size (log) & $\begin{array}{l}0.0003 \\
(0.26)\end{array}$ & $\begin{array}{l}0.0008 \\
(0.62)\end{array}$ & $\begin{array}{c}-0.0004 \\
(-0.28)\end{array}$ & $\begin{array}{l}0.0005 \\
(0.41)\end{array}$ \\
\hline Fund industry Herfindahl & $\begin{array}{c}-0.0105 \\
(-0.44)\end{array}$ & $\begin{array}{c}-0.0012 \\
(-0.05)\end{array}$ & $\begin{array}{c}-0.0091 \\
(-0.36)\end{array}$ & $\begin{array}{c}-0.0108 \\
(-0.44)\end{array}$ \\
\hline GDP per capita (log) & $\begin{array}{c}0.0001 \\
(0.03)\end{array}$ & $\begin{array}{l}0.0012 \\
(0.29)\end{array}$ & $\begin{array}{l}-0.0006 \\
(-0.16)\end{array}$ & $\begin{array}{l}0.0007 \\
(0.17)\end{array}$ \\
\hline Observations & 51,570 & 51,570 & 50,007 & 51,570 \\
\hline R-squared & 0.074 & 0.074 & 0.075 & 0.074 \\
\hline
\end{tabular}


Table 7 (continued)

\begin{tabular}{|c|c|c|c|c|}
\hline \multicolumn{5}{|l|}{ Panel B: By country of sale } \\
\hline & $(1)$ & $(2)$ & (3) & $(4)$ \\
\hline Active share & $\begin{array}{c}0.0549 * * * \\
(12.91)\end{array}$ & $\begin{array}{c}0.0722 * * * \\
(11.21)\end{array}$ & $\begin{array}{c}0.0350^{* * *} \\
(3.65)\end{array}$ & $\begin{array}{c}-0.0133 \\
(-1.03)\end{array}$ \\
\hline Explicit indexing (\% TNA) & & $\begin{array}{c}0.1196^{* * *} \\
(4.16)\end{array}$ & & \\
\hline Active share $\times$ Explicit indexing $(\%$ TNA) & & $\begin{array}{c}-0.1753 * * * \\
(-4.21)\end{array}$ & & \\
\hline Explicit indexing (average TSC) & & & $\begin{array}{c}-0.0158^{* *} \\
(-2.17)\end{array}$ & \\
\hline Active share $\times$ Explicit indexing (average TSC) & & & $\begin{array}{c}0.0233^{* *} \\
(2.18)\end{array}$ & \\
\hline Closet indexing (\% TNA) & & & & $\begin{array}{c}-0.1391 * * * \\
(-3.81)\end{array}$ \\
\hline Active share $\times$ Closet indexing $(\%$ TNA) & & & & $\begin{array}{c}0.2311^{* * *} \\
(4.67)\end{array}$ \\
\hline Tracking error & $\begin{array}{c}-0.1176^{* * *} \\
(-5.14)\end{array}$ & $\begin{array}{c}-0.1178^{* * *} \\
(-5.19)\end{array}$ & $\begin{array}{c}-0.1191^{* * *} \\
(-5.17)\end{array}$ & $\begin{array}{c}-0.1196 * * * \\
(-5.32)\end{array}$ \\
\hline Total shareholder cost & $\begin{array}{c}-0.0051^{* * *} \\
(-15.39)\end{array}$ & $\begin{array}{c}-0.0052 * * * \\
(-15.48)\end{array}$ & $\begin{array}{c}-0.0051 * * * \\
(-15.24)\end{array}$ & $\begin{array}{c}-0.0052 * * * \\
(-15.34)\end{array}$ \\
\hline Total net assets (log) & $\begin{array}{c}-0.0005^{* * *} \\
(-6.40)\end{array}$ & $\begin{array}{c}-0.0005^{* * *} \\
(-6.42)\end{array}$ & $\begin{array}{c}-0.0005^{* * *} \\
(-6.32)\end{array}$ & $\begin{array}{c}-0.0005^{* * *} \\
(-6.36)\end{array}$ \\
\hline Family total net assets (log) & $\begin{array}{c}0.0013^{* * *} \\
(5.63)\end{array}$ & $\begin{array}{c}0.0013^{* * *} \\
(5.29)\end{array}$ & $\begin{array}{c}0.0013^{* * *} \\
(5.48)\end{array}$ & $\begin{array}{c}0.0013^{* * *} \\
(5.97)\end{array}$ \\
\hline Fund age & $\begin{array}{c}0.0001^{* * *} \\
(4.92)\end{array}$ & $\begin{array}{c}0.0001^{* * *} \\
(4.77)\end{array}$ & $\begin{array}{c}0.0001^{* * *} \\
(4.87)\end{array}$ & $\begin{array}{c}0.0001^{* * *} \\
(4.59)\end{array}$ \\
\hline Flows & $\begin{array}{c}0.0000 \\
(0.36)\end{array}$ & $\begin{array}{l}0.0000 \\
(0.30)\end{array}$ & $\begin{array}{l}0.0000 \\
(0.43)\end{array}$ & $\begin{array}{c}0.0000 \\
(0.49)\end{array}$ \\
\hline International fund dummy & $\begin{array}{l}0.0019 \\
(0.60)\end{array}$ & $\begin{array}{l}0.0014 \\
(0.44)\end{array}$ & $\begin{array}{l}0.0018 \\
(0.58)\end{array}$ & $\begin{array}{c}-0.0002 \\
(-0.06)\end{array}$ \\
\hline Fund of fund dummy & $\begin{array}{c}-0.0023 \\
(-1.03)\end{array}$ & $\begin{array}{c}-0.0027 \\
(-1.20)\end{array}$ & $\begin{array}{l}-0.0026 \\
(-1.14)\end{array}$ & $\begin{array}{c}-0.0033 \\
(-1.45)\end{array}$ \\
\hline Off-shore fund dummy & $\begin{array}{c}-0.0042 * * * \\
(-5.16)\end{array}$ & $\begin{array}{c}-0.0043^{* * *} \\
(-5.27)\end{array}$ & $\begin{array}{c}-0.0043 * * * \\
(-5.31)\end{array}$ & $\begin{array}{c}-0.0042^{* * * *} \\
(-5.27)\end{array}$ \\
\hline Approval & $\begin{array}{c}-0.0010 \\
(-1.65)\end{array}$ & $\begin{array}{c}-0.0008 \\
(-1.47)\end{array}$ & $\begin{array}{c}-0.0009 \\
(-1.44)\end{array}$ & $\begin{array}{r}-0.0007 \\
(-1.20)\end{array}$ \\
\hline Judicial & $\begin{array}{c}0.0001 * * \\
(2.17)\end{array}$ & $\begin{array}{c}0.0001^{* *} \\
(2.15)\end{array}$ & $\begin{array}{l}0.0001 \\
(1.47)\end{array}$ & $\begin{array}{c}0.0001^{* *} \\
(2.49)\end{array}$ \\
\hline Fund industry size (log) & $\begin{array}{c}-0.0004 \\
(-1.21)\end{array}$ & $\begin{array}{c}-0.0004 \\
(-1.07)\end{array}$ & $\begin{array}{l}-0.0003 \\
(-0.97)\end{array}$ & $\begin{array}{c}-0.0004 \\
(-1.10)\end{array}$ \\
\hline Fund industry Herfindahl & $\begin{array}{c}-0.0079 * \\
(-1.71)\end{array}$ & $\begin{array}{c}-0.0080 \\
(-1.55)\end{array}$ & $\begin{array}{c}-0.0055 \\
(-0.89)\end{array}$ & $\begin{array}{c}-0.0092 * * \\
(-2.03)\end{array}$ \\
\hline GDP per capita (log) & $\begin{array}{l}0.0010 \\
(0.78)\end{array}$ & $\begin{array}{c}0.0010 \\
(0.81)\end{array}$ & $\begin{array}{l}0.0011 \\
(0.72)\end{array}$ & $\begin{array}{l}0.0011 \\
(0.90)\end{array}$ \\
\hline Observations & 346,711 & 346,711 & 340,940 & 346,711 \\
\hline R-squared & 0.101 & 0.102 & 0.101 & 0.103 \\
\hline
\end{tabular}




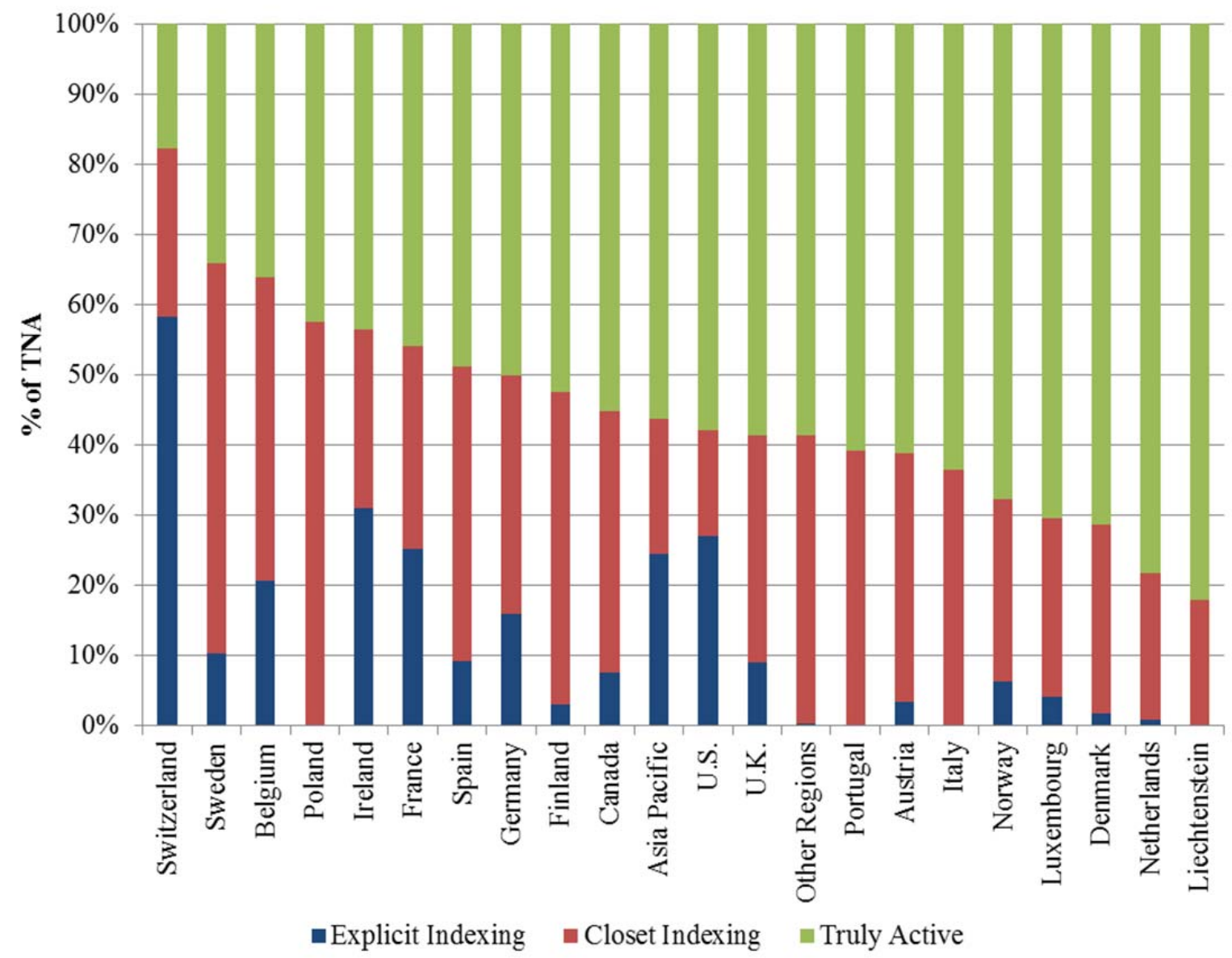

Fig. 1. Explicit and closet indexing by country of domicile. This figure shows the percentage that explicitly indexed funds represent of the TNA in a country (Explicit indexing), the percentage that active funds with active share measure below 0.6 represent of the TNA in a country (Closet indexing), and the percentage that active funds with active share measure above 0.6 represent of the TNA in a country (Truly active), as of December 2010. The sample includes open-end equity mutual funds from Lipper for which holdings are available in LionShares. 


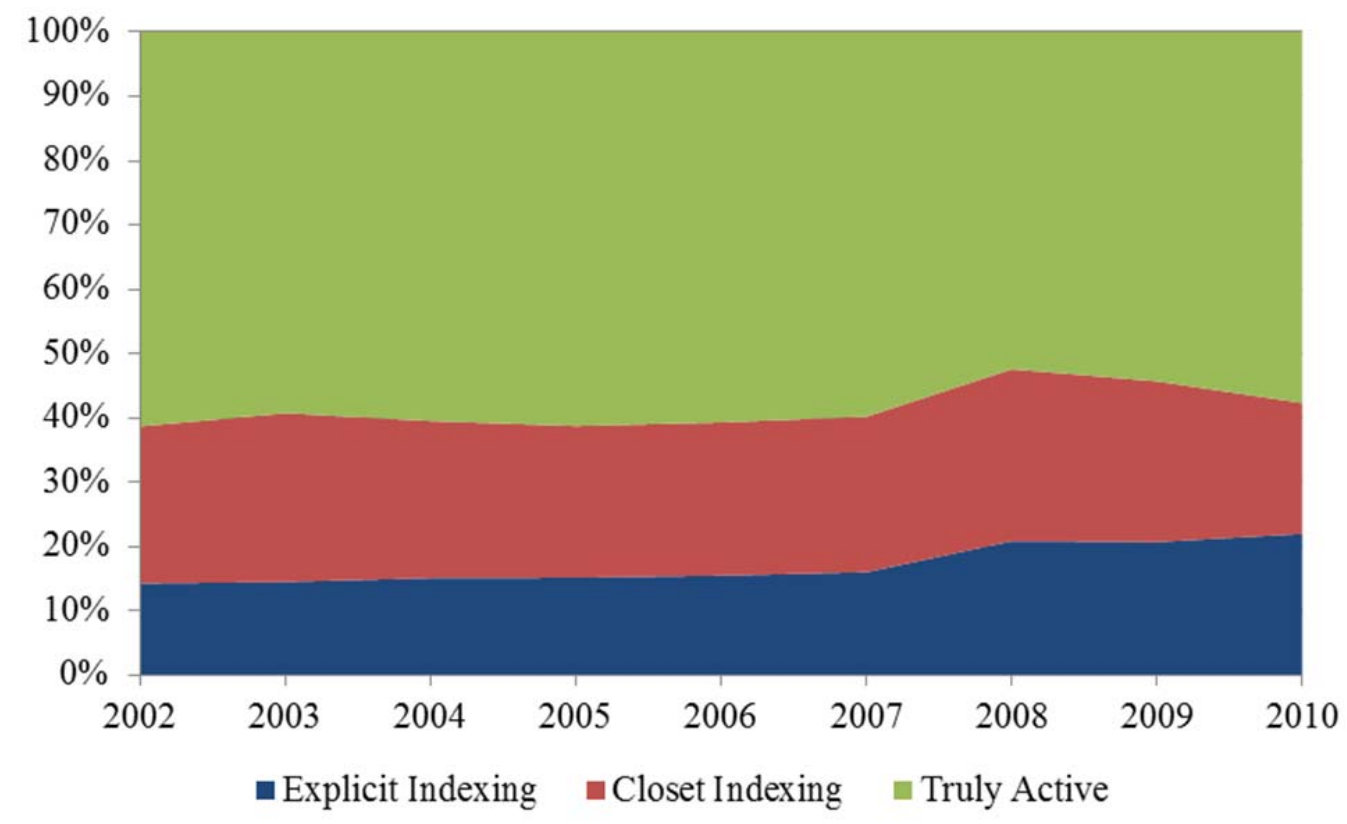

Fig. 2. Explicit and closet indexing by year. This figure shows the yearly percentage that explicitly indexed funds represent of the total TNA (Explicit indexing), the percentage that active funds with active share measure below 0.6 represent of the total TNA (Closet indexing), and the percentage that active funds with active share measure above 0.6 represent of the total TNA (Truly active). The sample includes open-end equity mutual funds from Lipper for which holdings are available in LionShares from 2002 to 2010. 


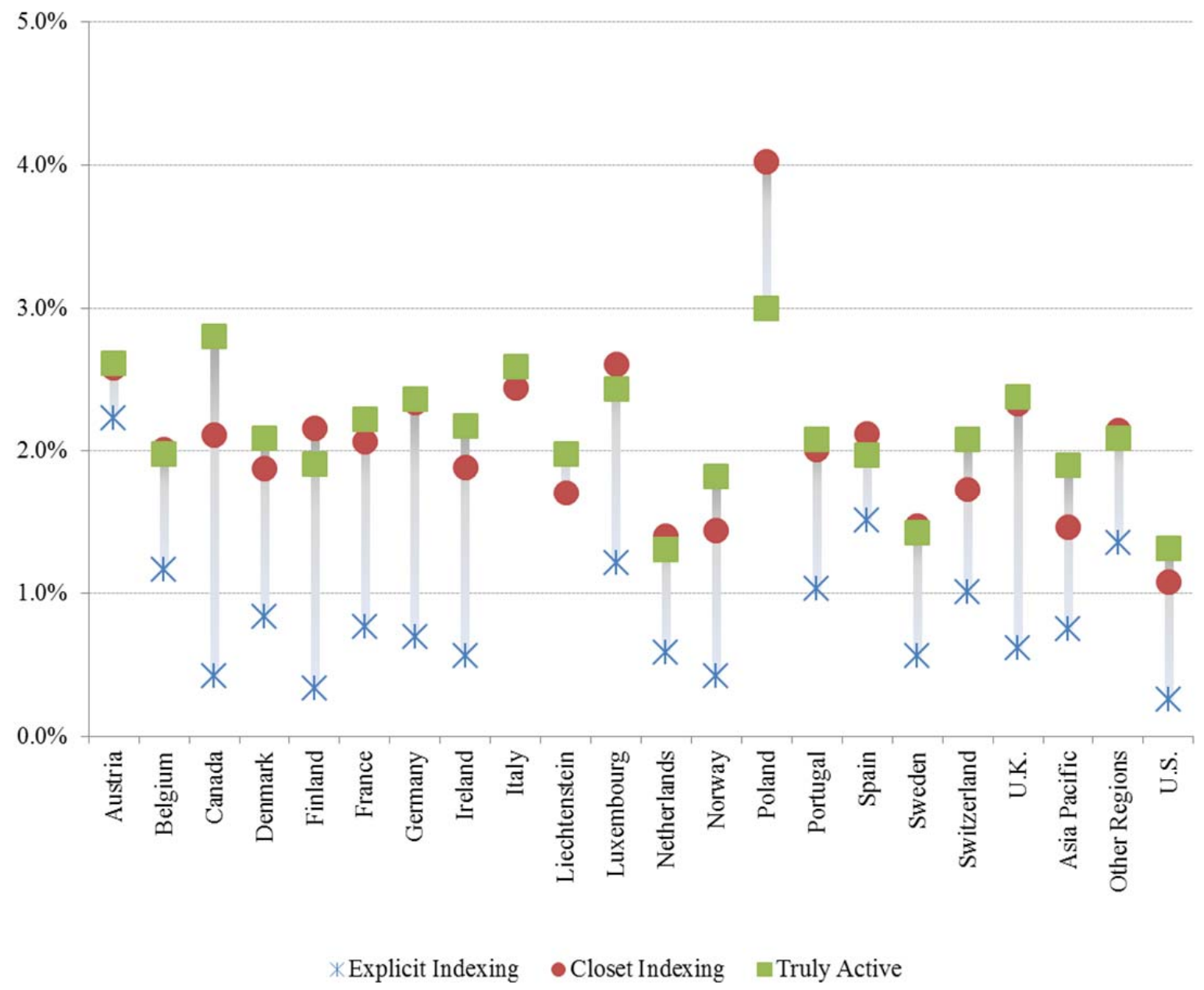

Fig 3. Average total shareholder cost by country of domicile. This figure shows the TNA-weighted average total shareholder cost of funds, defined as total expense ratio plus one-fifth of the front-end load, as of December 2010. The sample includes open-end equity mutual funds from Lipper for which holdings are available in LionShares. Explicit indexing includes index funds and exchange-traded funds. Closet indexing includes active funds with active share below 0.6. Truly active includes active funds with active share above 0.6 . 
Panel A: Explicit indexing (\% TNA)

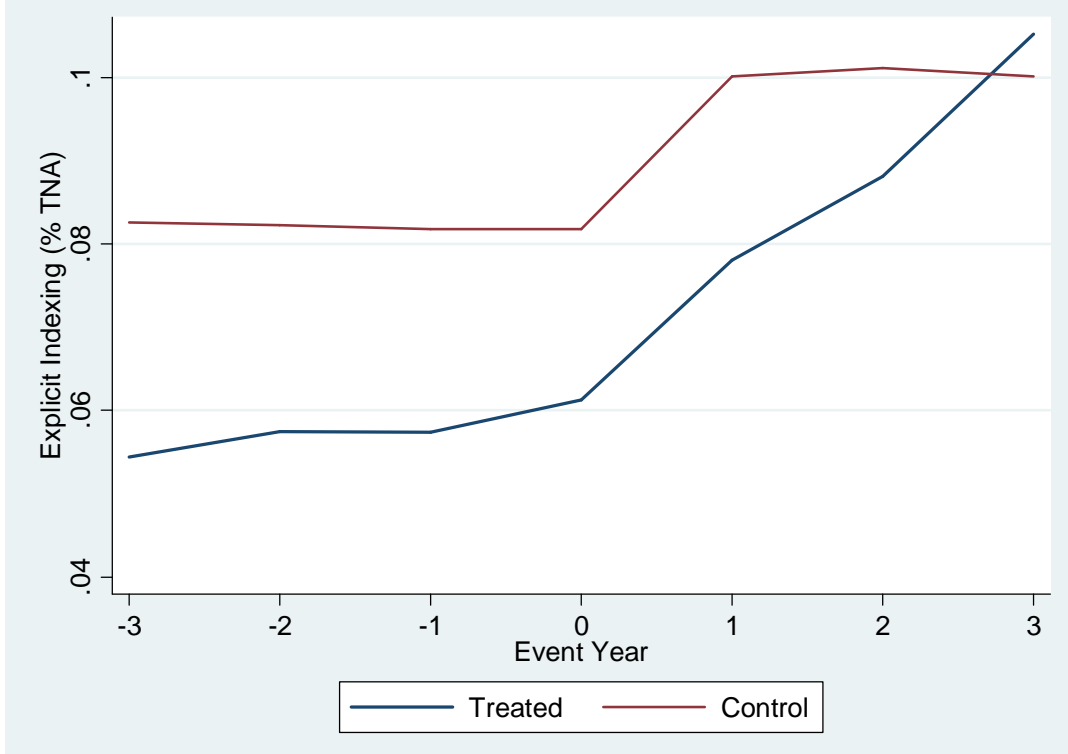

Panel B: Explicit indexing (average TSC)

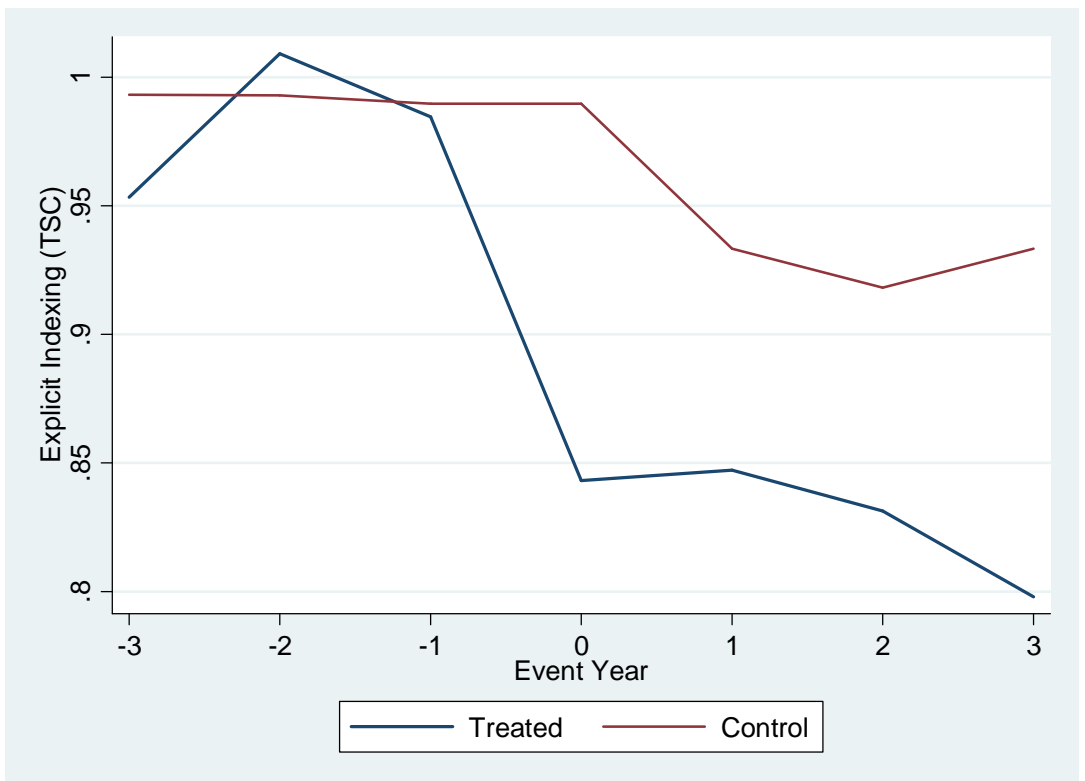

Fig. 4. Explicit indexing around passage of the Pension Act. This figure shows the percentage that explicitly indexed funds represent of the country's fund industry TNA (Panel A) and the average total shareholder costs of explicitly indexed funds (Panel B) for the treated group (countries that passed a pension act in year $t$ ) and the control group around passage of a pension act (between year -1 and year 0 ) in the funds' country of sale. Explicit indexing includes index funds and exchange-traded funds. The sample includes open-end equity mutual funds from Lipper for which holdings are available in LionShares. 
Panel A: Active share

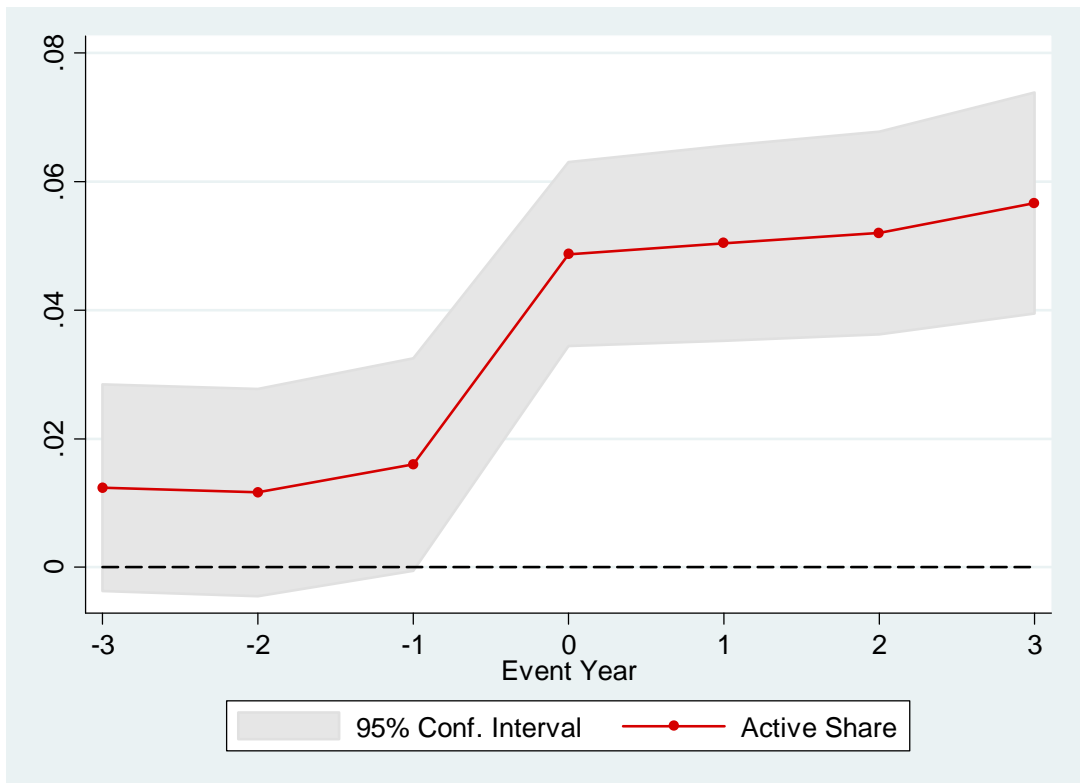

Panel B: Total shareholder cost

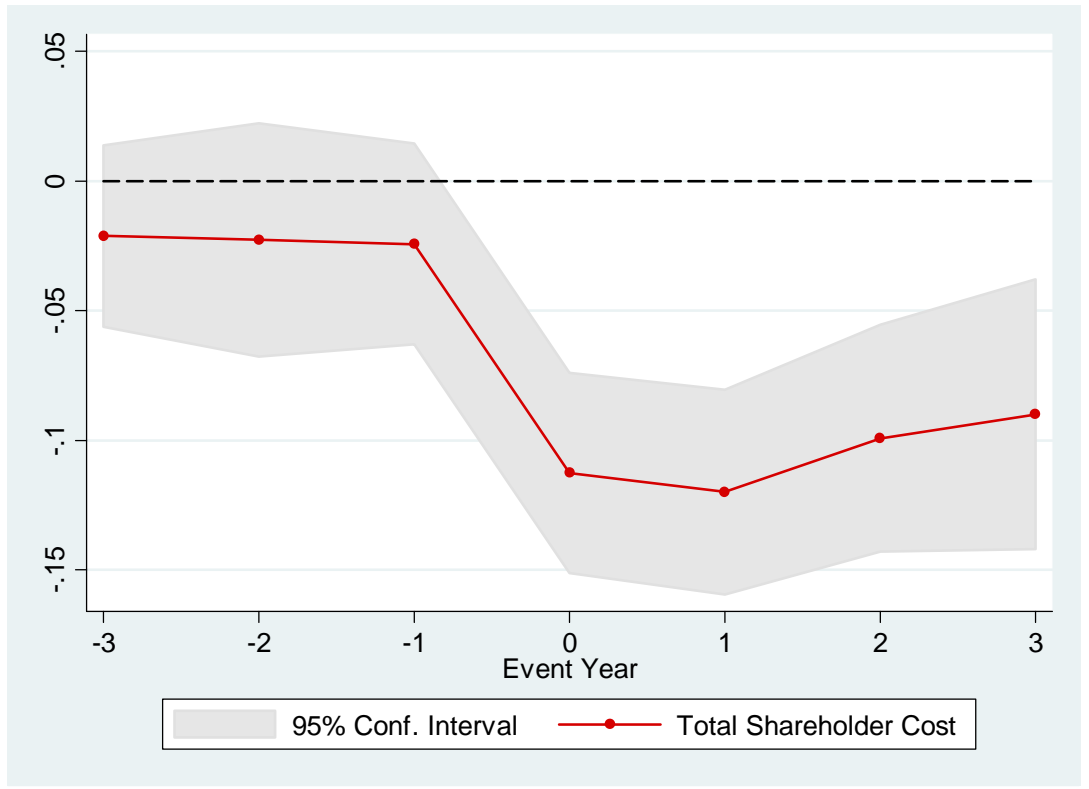

Fig. 5. Active management around passage of the Pension Act. This figure shows point estimates and 95\% confidence intervals for the effect on the average active share (Panel A) and average total shareholder cost (Panel D) of active funds in the treated group (countries that passed a pension act in year $t$ ) relative to the control group around the country's passage of a pension act (between year -1 and year 0 ) in the funds' country of sale. The sample includes open-end equity mutual funds from Lipper for which holdings are available in LionShares. 


\section{Appendix A: Variable definitions}

Panel A: Fund-level variables

\begin{tabular}{|c|c|}
\hline Active share & Percentage of a fund's portfolio holdings that differ from its benchmark index holdings. \\
\hline Tracking error & Standard deviation (annualized) estimated with three-year of past monthly benchmark adjusted return in U.S. dollars. \\
\hline Total shareholder cost & Annual total expense ratio plus one-fifth of the front-end load assuming a five-year holding period. \\
\hline Total net assets & Total net assets in millions of U.S. dollars. \\
\hline Family total net assets & Total net assets in millions of U.S. dollars of equity funds in the same management company excluding the own fund's TNA. \\
\hline Fund age & Number of years since the fund launch date. \\
\hline Flows & Percentage growth in TNA, net of internal growth (assuming reinvestment of dividends and distributions). \\
\hline International fund dummy & Dummy that takes the value of one if a fund's geographic focus is different from the fund's country of domicile. \\
\hline Fund of fund dummy & Dummy that takes the value of one if fund of fund. \\
\hline Off-shore fund dummy & Dummy that takes the value of one if fund is located in an off-shore domicile. \\
\hline Benchmark-adjusted return & Difference between the fund net return and its benchmark return (percentage per year). \\
\hline $\begin{array}{l}\text { Benchmark-adjusted return four-factor } \\
\text { alpha }\end{array}$ & $\begin{array}{l}\text { Four-factor alpha (percentage per year) estimated with three years of past monthly fund benchmark-adjusted returns in U.S. dollars and regional } \\
\text { factors (Asia, Europe, North America or Emerging Markets) or world factors in the case of world funds. }\end{array}$ \\
\hline \multicolumn{2}{|l|}{ Panel B: Country-level variables } \\
\hline Explicit indexing (\% TNA) & Percentage that explicitly indexed funds represent of the TNA of open-end equity mutual funds in the fund’s country. \\
\hline Explicit indexing (average TSC) & TNA-weighted average total shareholder cost of explicitly indexed funds in the fund's country. \\
\hline Closet indexing (\% TNA) & Percentage that active funds with active share below 0.6 represent of the TNA of open-end equity mutual funds in the fund's country. \\
\hline Approval & $\begin{array}{l}\text { Sum of two dummy variables that take value of one if (1) the fund startup requires regulatory approval and (2) the prospectus requires } \\
\text { regulatory approval (Khorana, Servaes, and Tufano (2005)). }\end{array}$ \\
\hline Judicial & $\begin{array}{l}\text { Judicial system quality defined as the sum of five variables (all variables are scaled between } 0 \text { and 10)): the efficiency of the judicial system, } \\
\text { rule of law, corruption, risk of expropriation and risk of contract repudiation (La Porta, Lopez-de-Silanes, Shleifer, and Vishny (1998)). }\end{array}$ \\
\hline Fund industry size & Sum of total net assets (in millions of U.S. dollar) for open-end equity mutual funds in the fund's country. \\
\hline Fund industry Herfindahl & Sum of squared market shares of fund management companies for open-end equity mutual funds in the fund's country. \\
\hline GDP per capita & Gross domestic product per capita in U.S. dollars in the fund’s country (World Development Indicators). \\
\hline
\end{tabular}




\title{
Internet Appendix to \\ "Indexing and Active Fund Management: International Evidence”
}

\author{
Martijn Cremers, University of Notre Dame \\ mcremers@nd.edu \\ Miguel A. Ferreira, Nova School of Business and Economics \\ miguel.ferreira@novasbe.pt \\ Pedro Matos, University of Virginia - Darden School of Business \\ matosp@darden.virginia.edu \\ Laura Starks, University of Texas at Austin \\ laura.starks@mccombs.utexas.edu
}

This Version: January 2015

\begin{abstract}
This internet appendix provides additional results and robustness analyses that are mentioned in the main text.
\end{abstract}




\section{Descriptive Statistics}

In Table IA.1, we provide summary statistics for the funds in our LionShares data over the 2002-2010 sample period. We expand on the statistics of the country characteristics in Table IA. 2 by showing the time series averages by country. Table IA.3 shows the number of fund share classes by country of sale and country of domicile.

\section{Explicit and Closet Indexing by Country and Benchmark Type}

A fund's active share may depend on the opportunities and constraints in the investment opportunity set of the fund manager, which will naturally differ across benchmarks. Table IA.4 groups the 88 benchmarks in our analysis into benchmark types: world, regional and country.

Table IA.5 shows the total net assets (TNA) and the market shares of explicit and closet indexing per country as of December 2010 in the three different benchmark types: world, regional, and country funds. We further separate funds with a country benchmark into country domestic (funds that invest in stocks of the same country where they are domiciled) and country - foreign (funds that invest in stocks of a country different from the one where they are domiciled). Panel A of Table IA.5 shows that the majority of equity mutual fund assets are invested domestically (\$4.4 trillion). The next most prevalent type of fund is regional funds (\$1.8 trillion), followed by world funds (\$1.2 trillion), and foreign country funds (\$0.4 trillion). However, the proportions are not universal across countries. For example, domestic funds are predominant in the U.S, but world and regional funds are relatively more important in European countries. Panel A of Table IA.5 also shows the amount of explicit indexing per country of domicile according to fund benchmark type. The level of explicit indexing is highest for domestic country funds, where $27 \%$ of the fund assets are indexed. Explicit indexing is used less frequently in world funds (12\%), regional funds (18\%), and foreign country funds (18\%). In 
addition, closet indexing is less common for funds pursuing global investment strategies (11\%) than for regional funds (24\%), domestic country funds (21\%), and foreign country funds (27\%). Panel B of Table IA.5 presents similar statistics by country of sale.

To take into account benchmark characteristics, we analyze the prevalence of indexing (as in Table 2) we separate the analysis by the country and benchmark type level (world, regional, country-domestic, and country-foreign). Table IA.6 presents the results by country of domicile (Panel A) and country of sale (Panel B). Consistent with Table 2, the evidence indicates that a strong regulatory environment and a large fund industry are positively correlated with the prevalence of explicit indexing and negatively correlated with closet indexing.

\section{Robustness}

We conduct several robustness checks on the results of Table 3 (active share) in Table IA.7, Table 5 (TSC) in Table IA.8, and Table 7 (performance) in Table IA.11. In each table, Panel A reports the results by country of domicile and Panel B by country of sale.

The first robustness check we conduct is to estimate the results using only the non-U.S. fund sample in order to alleviate the concern that funds domiciled or sold in the United States represent a large fraction of the observations and may distort our conclusions.

The second type of robustness check is to employ alternative methods of calculating funds' active shares. First, we construct the index weights based only on ETFs that undertake full physical replication of the indices. For the majority of the 88 benchmarks (see Table IA.4), we can identify a SPDR or iShares ETF that tracks these benchmarks. We call the active share measured against the ETF weights the Pure-ETF active share. Second, to address any potential issues with Lipper's assignment of the Technical Indicator Benchmark to each fund, we construct an alternative active share against all possible 88 benchmarks. Following Cremers and 
Petajisto (2009), we take the most representative benchmark for a fund in each year as the one with the lowest active share. We call this alternative measure the Minimum active share. We find that in our sample both of these alternative measures are highly correlated with the active share we employ in our main tests (correlation coefficients of 0.97 with the pure-ETF active share and 0.94 with the minimum active share). For active funds, the average (TNA-weighted) pure-ETF active share is $70 \%$ and the minimum active share is $65 \%$ which are similar to the levels of our main measure of active share. Finally, we calculate an Active Share (vs. Active) - the fraction of a fund's portfolio holdings that differ from the aggregate stock portfolio of active funds that track a fund's benchmark, in the spirit of the overlap measure of Wahal and Wang (2011).

The third robustness check considers alternative econometric specifications. We estimate the regression model using weighted least squares, where the total net assets of the fund are employed as the weights. We also estimate regressions using country of domicile fixed effects.

The fourth robustness check looks at specific types of funds. First, we use the sample of domestic funds, which is more commonly used in single-country studies as in the majority of the literature on U.S. equity mutual funds. We also present the analysis by measuring explicit and closet indexing separately by benchmark type (world, regional, country-domestic, and countryforeign) in each country. The diversity in the universe of stocks tracked by each benchmark has implications for the measurement of active share. For example, the SSgA World Index Equity Fund that tracks the MSCI World index (the most popular world index) holds over 1,600 stocks in its portfolio at the end of 2010, while the SPDR S\&P 500 ETF Trust tracking the S\&P 500 index (the most popular country index) holds 500 stocks. Many explicitly indexed funds do not engage in full physical replication. The average index or ETF fund tracking the S\&P 500 has an average of 334 stocks. The number of stock positions a fund needs to replicate its benchmark 
may matter for the measurement of active share.

Finally, we perform several other robustness checks of the fund performance regressions. These are reported in Table IA.11. We show that results are robust when we use benchmarkadjusted returns and several alternative risk-adjusted performance measures in alternative to the benchmark-adjusted return four-factor alpha. We use excess return (over U.S. T-bills) four-factor alphas and the information ratio (ratio of four-factor benchmark-adjusted return alpha by the standard deviation of residuals). Further we include the Amihud and Goyenko (2013) R-squared measure as an explanatory variable. Specifically, we use a logistic transformation of R-squared, $\mathrm{TR}^{2}=\log [\mathrm{sqrt}(\mathrm{R}$-squared)/(1 - sqrt(R-squared) $)]$ where R-squared is estimated using the benchmark-adjusted return four-factor model. A lower R-squared is indicative of more active management. We find that $\mathrm{TR}^{2}$ is insignificantly related to future fund performance in a regression that also includes active share and tracking error. Only active share is a statistically significant predictor of future fund performance. The coefficients on tracking error and $\mathrm{TR}^{2}$ are also insignificant in regressions that do not include active share.

We extend the differences-in-differences analysis of Pension Acts to examine the effect on fund performance. We estimate the equivalent to the performance regression in column (2) of Table 7, but replacing the market share of explicitly indexed funds with the Post pension act (year $>=0$ ) dummy variable. The results in Table IA.12 of the Internet Appendix are consistent with those in Table 7. We find that the coefficient on the Post pension act (year $>=0$ ) variable is positive and significant, which indicates that performance improves more for the treatment group than the control group following the passage of the Pension Act. Moreover, the coefficient on active share is positive and significant and the interaction between active share and Post pension act (year $>=0$ ) is negative and significant in Panel B (estimates by country of sale). 


\section{Instrumental Variable Regressions}

As an alternative strategy to address endogeneity concerns, we employ instrumental variables methods. We use two instruments for explicit indexing - i.e., variables that are correlated with the availability of explicitly indexed funds in a given market but should be uncorrelated with the active share and fees charged by active funds (other than through their correlation with explicitly index funds). The first instrument is the financial sophistication of retail investors in a country, which should be associated with the demand for low-cost alternatives to achieve beta exposure. That is, financially literate investors are more likely to be aware that passive funds can deliver the same fundamental beta exposure as active funds but at a lower cost. Thus, those investors will have higher demand for the indexed funds. We proxy for financial literacy in a country using the variable Financial sophistication measured by the World Economic Forum in the

annual Global Competitiveness Report using the question "The level of sophistication of financial markets is higher than international norms.”

The second instrument is based on the development of the defined contribution (DC) pension market in a country, which can increase the demand for passive funds providing beta exposure (for example, by offering at least one passive fund in their menu of investment options). The instrument, DC pension market, takes the value of one if a country's DC market is "Developed", the value of one-half if the market is "Nascent", and zero if there is no market, according to the KPMG (2011) classification.

Table IA.9 reports estimates of two-stage least squares (2SLS) active share regressions using instrumental variables methods. Table IA.10 reports similar 2SLS regressions of the total shareholder cost (TSC) of active funds. These results lead to the conclusion that indexing plays an important role in enhancing market contestability in the fund industry worldwide. The 
evidence suggests a link from more passive management in a market to more competitive strategies by active funds such as lower fees and more product differentiation. However, these results should be interpreted with caution since they rely on the validity of the instruments.

We consider one more analysis designed to capture the effects of the increased presence of explicitly indexed funds on the behavior and pricing of the active funds in a country. Specifically, we evaluate whether the hypothesized direct competitive shocks occur given the entry of low-cost explicitly indexed funds in different markets. We focus on the first time an index fund or ETF is available in a given country and benchmark index, with the advantage that such effects are staggered over time. In unreported results, we find that entry of indexed funds is associated with an increase in active shares and reduced fees of active funds in the country. However, the coefficients from the analysis are imprecisely estimated, as over four-fifths of country-benchmarks already have indexed funds at the start of our sample period. There is also the possibility that these events are not truly exogenous because the entry decision of passive funds may be influenced by the level of competition in the local fund industry in the first place. 


\section{Table IA.1}

Summary statistics

This table presents mean, median, standard deviation, minimum, maximum and number of observations of variables. The sample includes open-end active equity mutual funds taken from Lipper for which holdings are available in LionShares from 2002 to 2010.

\begin{tabular}{|c|c|c|c|c|c|c|}
\hline Variable & Mean & Median & $\begin{array}{l}\text { Standard } \\
\text { deviation }\end{array}$ & Minimum & Maximum & Observations \\
\hline Active share & 0.7050 & 0.7437 & 0.2190 & 0.0000 & 1.0000 & 67,195 \\
\hline Pure-ETF active share & 0.7047 & 0.7430 & 0.2240 & 0.0000 & 1.0000 & 52,984 \\
\hline Minimum active share & 0.6687 & 0.7009 & 0.2069 & 0.0000 & 1.0000 & 66,893 \\
\hline $\mathrm{TR}^{2}$ & 0.1096 & 0.1008 & 0.7621 & -3.8332 & 4.6313 & 62,078 \\
\hline Tracking error & 0.0705 & 0.0594 & 0.0467 & 0.0027 & 1.7320 & 62,096 \\
\hline Total shareholder cost & 2.12 & 2.19 & 0.83 & 0.13 & 4.46 & 67,146 \\
\hline Total net assets ( $\$$ million) & 634 & 115 & 3,128 & 0 & 193,453 & 67,195 \\
\hline Family total net assets (\$ million) & 20,824 & 4,228 & 72,265 & 0 & 832,483 & 67,184 \\
\hline Fund age & 10.70 & 8.50 & 9.44 & 0.00 & 86.42 & 67,195 \\
\hline Flows & 0.1402 & -0.0357 & 0.7287 & -0.8563 & 4.7889 & 60,461 \\
\hline International fund dummy & 0.5899 & 1.0000 & 0.4919 & 0.0000 & 1.0000 & 67,177 \\
\hline Fund of fund dummy & 0.0135 & 0.0000 & 0.1156 & 0.0000 & 1.0000 & 67,195 \\
\hline Off-shore fund dummy & 0.1782 & 0.0000 & 0.3827 & 0.0000 & 1.0000 & 67,195 \\
\hline Benchmark-adjusted return & 0.0004 & -0.0061 & 0.0838 & -0.2818 & 0.3309 & 66,104 \\
\hline Benchmark-adjusted four-factor alphas & -0.0014 & -0.0049 & 0.0793 & -0.2602 & 0.2819 & 56,991 \\
\hline Excess return four-factor alphas & -0.0019 & -0.0164 & 0.1223 & -0.3170 & 0.4967 & 57,460 \\
\hline Information ratio & -0.0545 & -0.1025 & 1.2898 & -3.4331 & 3.2447 & 56,991 \\
\hline Explicit indexing (\% TNA) & 0.1280 & 0.0870 & 0.1109 & 0.0000 & 0.9574 & 67,195 \\
\hline Explicit indexing (average TSC) & 0.7696 & 0.6499 & 0.5271 & 0.1546 & 2.9700 & 64,558 \\
\hline Closet indexing (\% TNA) & 0.3312 & 0.3233 & 0.1484 & 0.0000 & 1.0000 & 67,195 \\
\hline Approval & 1.49 & 1.00 & 0.50 & 1.00 & 2.00 & 67,195 \\
\hline Judicial & 42.96 & 47.01 & 7.01 & 29.67 & 49.96 & 67,195 \\
\hline Fund industry size (\$ million) & $1,523,089$ & 436,414 & $2,037,732$ & 652 & $6,219,298$ & 67,195 \\
\hline Fund industry Herfindahl & 0.0697 & 0.0476 & 0.0564 & 0.0230 & 0.3482 & 67,195 \\
\hline GDP per capita (\$) & 49,033 & 44,117 & 25,301 & 563 & 118,841 & 66,663 \\
\hline Financial sophistication & 6.10 & 6.30 & 0.59 & 3.20 & 6.80 & 66,005 \\
\hline DC pension market & 0.5357 & 0.5000 & 0.4294 & 0.0000 & 1.0000 & 65,158 \\
\hline
\end{tabular}


Table IA.2

Time series averages of country variables

This table presents time-series average of country variables in the 2002-2010 period.

\begin{tabular}{|c|c|c|c|c|c|c|c|c|}
\hline Country & Approval & Judicial & $\begin{array}{c}\text { Fund } \\
\text { industry size } \\
\text { (\$ million) }\end{array}$ & $\begin{array}{c}\text { Fund } \\
\text { industry } \\
\text { Herfindahl } \\
\end{array}$ & $\begin{array}{l}\text { GDP per } \\
\text { capita }(\$)\end{array}$ & $\begin{array}{c}\text { Financial } \\
\text { sophistication }\end{array}$ & $\begin{array}{c}\text { DC pension } \\
\text { market }\end{array}$ & $\begin{array}{l}\text { Pension } \\
\text { act year }\end{array}$ \\
\hline Australia & 2 & 47 & 207,996 & 0.0468 & 40,831 & 6.21 & 1.0 & 1992 \\
\hline Austria & 2 & 47 & 18,380 & 0.1288 & 40,953 & 5.32 & 0.0 & 1990 \\
\hline Belgium & 2 & 47 & 34,468 & 0.3066 & 38,895 & 5.71 & 0.0 & 2003 \\
\hline Brazil & 2 & 32 & 90,809 & 0.1114 & 9,744 & 5.40 & 1.0 & \\
\hline Canada & 1 & 48 & 333,830 & 0.0468 & 39,104 & 6.20 & 0.5 & 1997 \\
\hline China & 1 & 31 & 167,406 & 0.0396 & 3,838 & 3.20 & 0.5 & \\
\hline Denmark & 1 & 49 & 25,568 & 0.1055 & 51,775 & 5.85 & 1.0 & 2006 \\
\hline Finland & 1 & 49 & 22,705 & 0.1590 & 42,183 & 5.93 & 0.5 & 2007 \\
\hline France & 2 & 45 & 266,107 & 0.0502 & 37,363 & 5.81 & 0.5 & 2003 \\
\hline Germany & 1 & 47 & 136,732 & 0.1563 & 36,697 & 5.97 & 0.5 & 2004 \\
\hline Hong Kong & 2 & 44 & 29,087 & 0.1902 & 29,518 & 6.43 & 1.0 & \\
\hline India & 2 & 31 & 31,028 & 0.0929 & 1,095 & 5.01 & 0.5 & \\
\hline Ireland & 1 & 35 & 205,832 & 0.0472 & 50,147 & 5.94 & 1.0 & \\
\hline Israel & 2 & 40 & 3,719 & 0.0830 & 27,313 & 5.90 & 1.0 & \\
\hline Italy & 2 & 40 & 67,003 & 0.0966 & 31,789 & 4.38 & 0.5 & 2000 \\
\hline Japan & 2 & 47 & 152,159 & 0.0988 & 37,550 & 5.21 & & 2001 \\
\hline Liechtenstein & 1 & 31 & 6,520 & 0.1780 & & & & \\
\hline Luxembourg & 1 & 31 & 679,193 & 0.0310 & 95,617 & 6.20 & 0.0 & \\
\hline Malaysia & 2 & 39 & 10,381 & 0.2407 & 7,037 & 5.25 & 1.0 & \\
\hline Netherlands & 2 & 49 & 41,967 & 0.1336 & 43,256 & 6.08 & 0.5 & 2006 \\
\hline Norway & 1 & 50 & 25,407 & 0.1716 & 71,472 & 5.48 & 1.0 & 2006 \\
\hline Poland & 1 & 31 & 7,933 & 0.1082 & 10,585 & 4.01 & 0.5 & 2004 \\
\hline Portugal & 1 & 39 & 2,798 & 0.1846 & 19,557 & 5.22 & 0.0 & 2007 \\
\hline Singapore & 1 & 45 & 15,137 & 0.0656 & 34,350 & 6.01 & 1.0 & \\
\hline South Africa & 1 & 32 & 21,763 & 0.0963 & 6,076 & 5.92 & 1.0 & \\
\hline Spain & 2 & 39 & 26,100 & 0.0957 & 28,049 & 5.40 & 0.5 & 2002 \\
\hline Sweden & 2 & 49 & 88,017 & 0.1637 & 43,446 & 6.08 & 0.0 & 2000 \\
\hline Switzerland & 1 & 50 & 74,268 & 0.2100 & 56,964 & 6.60 & 1.0 & 2003 \\
\hline Taiwan & 1 & 40 & 23,140 & 0.0633 & 17,472 & 4.79 & & \\
\hline Thailand & 2 & 30 & 4,667 & 0.1177 & 3,845 & 4.71 & 0.5 & \\
\hline United Kingdom & 1 & 47 & 562,228 & 0.0257 & 37,855 & 6.73 & 0.0 & 2004 \\
\hline United States & 2 & 48 & $4,617,651$ & 0.0470 & 43,806 & 6.44 & 1.0 & 1974 \\
\hline Total & 1.49 & 42.96 & $1,523,089$ & 0.0697 & 49,033 & 6.10 & 0.5357 & \\
\hline
\end{tabular}




\section{Table IA.3}

Number of fund share classes by country of domicile and country of sale

This table presents the number of fund share classes offered by country of domicile and country of sale for the sample of open-end equity mutual funds taken from Lipper for which holdings are available in LionShares as of December 2010. Rows correspond to the fund legal country of domicile. Columns correspond to countries where fund share classes are approved for sale. A fund share class is counted multiple times based on how many countries it is approved for sale according to Lipper.

\begin{tabular}{|c|c|c|c|c|c|c|c|c|c|c|c|c|c|c|c|c|c|c|c|c|c|c|c|c|}
\hline \multicolumn{25}{|c|}{ Country of sale } \\
\hline $\begin{array}{l}\text { Country of } \\
\text { domicile }\end{array}$ & Aus. & Bel. & Can. & Den. & Finl. & Fran. & Ger. & Irel. & Italy & Liech. & Lux. & Neth. & Nor. & Pol. & Port. & Spain & Swe. & Switz. & U.K. & U.S. & $\begin{array}{l}\text { Asia } \\
\text { Pac. }\end{array}$ & $\begin{array}{l}\text { Other } \\
\text { Reg. }\end{array}$ & $\begin{array}{l}\text { Other } \\
\text { Count. }\end{array}$ & Total \\
\hline Austria & 324 & & & & & 20 & 195 & & 39 & & & 3 & & 31 & & 27 & & 24 & 9 & & & & 263 & 935 \\
\hline Belgium & 76 & 273 & & & 6 & 110 & 105 & & 4 & & 131 & 104 & & & & 26 & 7 & 39 & 1 & & & & 142 & 1,024 \\
\hline Canada & & & 2,083 & & & & & & & & & & & & & & & & & & 1 & & 1 & 2,085 \\
\hline Denmark & & & & 203 & 1 & 9 & 20 & & & & 17 & 19 & 16 & & & & 24 & 19 & 17 & & & & 2 & 347 \\
\hline Finland & & & & & 155 & 2 & 2 & & & & 2 & 2 & 20 & & & & 54 & & & & & & 14 & 251 \\
\hline France & 36 & 54 & & & & 772 & 130 & 39 & 117 & & 87 & 75 & & & & 114 & 42 & 137 & 65 & & 14 & & 9 & 1,691 \\
\hline Germany & 173 & 6 & & & & 34 & 411 & & 11 & & 31 & 20 & & & 2 & 9 & & 59 & 1 & & 16 & & 42 & 815 \\
\hline Ireland & 463 & 236 & & 151 & 300 & 538 & 697 & 923 & 296 & & 433 & 503 & 256 & 105 & 82 & 434 & 511 & 615 & 818 & & 769 & 41 & 691 & 8,862 \\
\hline Italy & & & & & & 4 & & & 136 & & & & & & & & & & & & & & & 140 \\
\hline Liechtenstein & 26 & & & & & & 37 & & & & & & & & & & & 57 & 3 & & 3 & & 112 & 238 \\
\hline Luxembourg & 4,627 & 2,660 & 31 & 2,334 & 3,451 & 4,628 & 5,571 & 1,754 & 3,719 & 60 & 6,663 & 4,269 & 2,852 & 1,572 & 3,223 & 4,422 & 4,307 & 5,333 & 4,629 & & 6,095 & 320 & 18,832 & 91,352 \\
\hline Netherlands & 1 & 3 & & & & 2 & 2 & & 1 & & & 75 & & & & 1 & & 2 & 2 & & 1 & & 3 & 93 \\
\hline Norway & & & & 3 & 13 & & & & & & 3 & 12 & 117 & & & & 29 & 3 & 13 & & & & 2 & 195 \\
\hline Poland & & & & & & & & & & & & & & 46 & & & & & & & & & & 46 \\
\hline Portugal & & & & & & & & & & & & & & & 53 & & & & & & & & 5 & 58 \\
\hline Spain & & & & & & & & & 2 & & & & & & 2 & 269 & & & & & & & & 273 \\
\hline Sweden & 4 & & & & 16 & 5 & 1 & & & & 12 & 5 & 38 & & & & 266 & & & & 2 & & 26 & 375 \\
\hline Switzerland & 6 & & & & & 4 & 7 & & & & 15 & & & & & & & 369 & & & 7 & & 30 & 438 \\
\hline United Kingdom & 124 & 63 & & 50 & 31 & 139 & 175 & 129 & 34 & & 91 & 100 & 25 & 1 & 28 & 57 & 47 & 152 & 1,366 & & 85 & 13 & 224 & 2,934 \\
\hline United States & 1 & 6 & & & & 2 & 7 & & & & & 7 & & & & & 24 & & & 8,976 & 32 & & 615 & 9,670 \\
\hline Asia Pacific & & & & & & & & 1 & & & & & & & & & & & & & 1,650 & & 224 & 1,875 \\
\hline Other Regions & & & & & & & & & & & & & & & & & & & & & & 168 & 57 & 225 \\
\hline Total & 5,861 & 3,301 & 2,114 & 2,741 & 3,973 & 6,269 & 7,360 & 2,846 & 4,359 & 60 & 7,485 & 5,194 & 3,324 & 1,755 & 3,390 & 5,359 & 5,311 & 6,809 & 6,924 & 8,976 & 8,675 & 542 & 21,294 & 123,922 \\
\hline
\end{tabular}




\section{Table IA.4}

List of benchmark indices

This table lists the 88 benchmarks (Technical Indicator Benchmarks) for the sample of open-end active equity mutual funds taken from Lipper with portfolio holdings in LionShares as of December 2010. The sum of total net assets (in billions of U.S. dollars) of the equity mutual funds tracking each benchmark is presented in brackets.

\begin{tabular}{|c|c|c|c|}
\hline World & Regional & & Country \\
\hline MSCI World [\$456] & MSCI EM (Emerging Markets) [\$549] & Australia & ASX All Ordinaries [\$20] \\
\hline MSCI World ex USA [\$320] & MSCI EU Growth [\$195] & Austria & ATX Prime $[\$ 2]$ \\
\hline MSCI AC World [\$96] & STOXX Europe 50 [\$192] & Belgium & Brussels SE [\$2] \\
\hline FTSE AW/Oil \& Gas [\$62] & MSCI AC Asia Pacific ex Japan [\$177] & Canada & S\&P/TSX Composite [\$180] \\
\hline MSCI World Growth [\$53] & MSCI Europe Australia \& Far East ex-Japan [\$158] & & MSCI Canada Small Cap [\$16] \\
\hline MSCI World ex USA Small Cap [\$46] & MSCI EAFE [\$119] & & FTSE Canada/Oil \& Gas [\$11] \\
\hline FTSE Gold Mines [\$39] & EURO STOXX 50 [\$92] & Denmark & OMX Copenhagen All Share [\$3] \\
\hline FTSE AW/Mining [\$26] & MSCI EM Latin America [\$76] & Finland & OMX Helsinki $[\$ 6]$ \\
\hline Dow Jones Wilshire Global Ex-US [\$19] & S\&P North American Natural Resources [\$59] & France & CAC $40[\$ 25]$ \\
\hline FTSE AW (Dev)/Real Estate Inv. [\$16] & MSCI Europe ex UK [\$57] & Germany & DAX 30 [\$48] \\
\hline FTSE AW/Utilities [\$15] & MSCI AC Asia Pacific [\$44] & Italy & MSCI Italy [\$7] \\
\hline FTSE EPRA/NAREIT Developed [\$15] & MSCI EM Eastern Europe [\$33] & Netherlands & $\mathrm{AEX}[\$ 8]$ \\
\hline MSCI World Small Cap [\$14] & MSCI Europe Small Cap [\$28] & Norway & MSCI Norway [\$15] \\
\hline MSCI World Value [\$12] & MSCI Golden Dragon [\$25] & Poland & Poland WIG [\$6] \\
\hline MSCI World ex Australia [\$8] & MSCI BRIC [\$24] & Portugal & Portugal PSI General [\$1] \\
\hline LCI UK \& World Equity (50:50) [\$5] & MSCI Nordic Countries [\$17] & Spain & Madrid SE [\$4] \\
\hline \multirow[t]{38}{*}{ Dow Jones Commodity [\$1] } & EURO STOXX [\$5] & Sweden & OMX Stockholm All Share [\$54] \\
\hline & & Switzerland & Swiss Performance Index [\$40] \\
\hline & & United & FTSE 100 [\$157] \\
\hline & & Kingdom & FTSE All-Share [\$79] \\
\hline & & & Hoare Govett Small Cap Extended [\$20] \\
\hline & & United & S\&P $500[\$ 979]$ \\
\hline & & States & Russell 1000 Growth [\$636] \\
\hline & & & Russell 3000 [\$400] \\
\hline & & & Russell MidCap [\$275] \\
\hline & & & Russell MidCap Growth [\$252] \\
\hline & & & Russell 1000 [\$206] \\
\hline & & & Russell 2000 [\$184] \\
\hline & & & Russell 1000 Value [\$139] \\
\hline & & & Russell 2000 Growth [\$100] \\
\hline & & & S\&P 500 Growth [\$92] \\
\hline & & & S\&P MidCap 400 [\$92] \\
\hline & & & S\&P 500 Value [\$73] \\
\hline & & & S\&P $100[\$ 72]$ \\
\hline & & & S\&P U.S. Real Estate Investment Trust [\$63] \\
\hline & & & S\&P 400 Value $[\$ 61]$ \\
\hline & & & Russell MidCap Value [\$51] \\
\hline & & & Dow Jones US Healthcare [\$43] \\
\hline & & & Russell 2000 Value [\$42] \\
\hline & & & S\&P 600 Small Cap [\$27] \\
\hline & & & NASDAQ Composite [\$13] \\
\hline & & Asia Pacific & Topix $[\$ 82]$ \\
\hline & & & CSI $300[\$ 75]$ \\
\hline & & & BSE 100 [\$72] \\
\hline & & & MSCI China [\$47] \\
\hline & & & Hang Seng [\$14] \\
\hline & & & Taiwan Weighted Price [\$12] \\
\hline & & & Thailand SET [\$6] \\
\hline & & & FTSE Bursa Malaysia KLCI [\$3] \\
\hline & & & Singapore Straits Time [\$3] \\
\hline & & Other & Russia Moscow Times [\$19] \\
\hline & & Regions & FTSE South Africa [\$18] \\
\hline & & & BOVESPA (Ibovespa) [\$17] \\
\hline & & & TASE $25[\$ 1]$ \\
\hline
\end{tabular}


Table IA.5

Explicit and closet indexing by country and benchmark type

This table presents total net assets (TNA) and market shares of explicit and closet indexing per country and benchmark type. The sample consists of open-end equity mutual funds taken from Lipper with portfolio holdings in LionShares as of December 2010. Explicit indexing is the percentage that explicitly indexed funds represent of the TNA in a country. Closet indexing is the percentage of the TNA by active funds with active share measure below 0.6. Funds are classified based on their benchmark as world funds, regional funds, country - domestic funds (funds investing in their country of domicile) and country - foreign funds (funds investing in a country different from their domicile). Panel A presents statistics based on the primary fund country of domicile and Panel B presents statistics based on the fund share class country of sale.

\begin{tabular}{|c|c|c|c|c|c|c|c|c|c|c|c|c|}
\hline \multicolumn{13}{|c|}{ Panel A: By country of domicile } \\
\hline \multirow[b]{2}{*}{ Domicile } & \multicolumn{3}{|c|}{ World funds } & \multicolumn{3}{|c|}{ Regional funds } & \multicolumn{3}{|c|}{ Country - domestic funds } & \multicolumn{3}{|c|}{ Country - foreign funds } \\
\hline & $\begin{array}{c}\text { TNA } \\
\text { (\$ billion) }\end{array}$ & $\begin{array}{c}\text { Explicit } \\
\text { indexing } \\
(\%)\end{array}$ & $\begin{array}{c}\text { Closet } \\
\text { indexing } \\
(\%)\end{array}$ & $\begin{array}{c}\text { TNA } \\
\text { (\$ billion) }\end{array}$ & $\begin{array}{c}\text { Explicit } \\
\text { indexing } \\
(\%)\end{array}$ & $\begin{array}{c}\text { Closet } \\
\text { indexing } \\
(\%)\end{array}$ & $\begin{array}{c}\text { TNA } \\
\text { (\$ billion) }\end{array}$ & $\begin{array}{c}\text { Explicit } \\
\text { indexing } \\
(\%)\end{array}$ & $\begin{array}{c}\text { Closet } \\
\text { indexing } \\
(\%)\end{array}$ & $\begin{array}{c}\text { TNA } \\
\text { (\$ billion) }\end{array}$ & $\begin{array}{c}\text { Explicit } \\
\text { indexing } \\
(\%)\end{array}$ & $\begin{array}{c}\text { Closet } \\
\text { indexing } \\
(\%)\end{array}$ \\
\hline Austria & 3.4 & 2 & 7 & 8.3 & 1 & 35 & 1.4 & 0 & 100 & 1.8 & 20 & 39 \\
\hline Belgium & 3.2 & 5 & 9 & 9.1 & 22 & 49 & 1.7 & 6 & 91 & 4.0 & 37 & 37 \\
\hline Canada & 77.1 & 4 & 3 & 15.4 & 4 & 13 & 204.9 & 10 & 56 & 29.1 & 3 & 9 \\
\hline Denmark & 10.3 & 0 & 5 & 12.7 & 1 & 21 & 3.1 & 0 & 98 & 4.4 & 9 & 44 \\
\hline Finland & 2.7 & 0 & 0 & 11.5 & 2 & 24 & 5.7 & 8 & 81 & 6.2 & 1 & 69 \\
\hline France & 24.1 & 15 & 4 & 68.5 & 30 & 28 & 24.9 & 10 & 68 & 16.6 & 42 & 12 \\
\hline Germany & 50.4 & 0 & 1 & 42.4 & 27 & 28 & 42.3 & 21 & 78 & 4.4 & 38 & 38 \\
\hline Ireland & 42.8 & 25 & 15 & 97.7 & 28 & 37 & 0.0 & & & 82.0 & 37 & 17 \\
\hline Italy & 6.5 & 0 & 0 & 17.5 & 0 & 37 & 4.2 & 0 & 100 & 3.1 & 0 & 24 \\
\hline Liechtenstein & 3.1 & 0 & 2 & 1.7 & 0 & 18 & 0.0 & & & 1.2 & 0 & 58 \\
\hline Luxembourg & 170.0 & 3 & 13 & 389.8 & 5 & 26 & 0.0 & & & 190.8 & 4 & 36 \\
\hline Netherlands & 22.1 & 0 & 4 & 4.4 & 0 & 50 & 6.7 & 5 & 56 & 0.4 & 0 & 70 \\
\hline Norway & 11.3 & 13 & 6 & 13.9 & 4 & 11 & 14.5 & 3 & 53 & 1.7 & 19 & 47 \\
\hline Poland & 1.7 & 0 & 0 & 0.7 & 0 & 7 & 5.9 & 0 & 81 & 0.0 & & \\
\hline Portugal & 0.5 & 0 & 0 & 0.8 & 0 & 31 & 0.5 & 1 & 99 & 0.3 & 0 & 11 \\
\hline Spain & 2.4 & 0 & 0 & 6.4 & 6 & 41 & 3.3 & 20 & 69 & 0.9 & 16 & 68 \\
\hline Sweden & 25.6 & 1 & 13 & 25.8 & 7 & 55 & 52.2 & 17 & 73 & 10.0 & 10 & 76 \\
\hline Switzerland & 11.7 & 33 & 13 & 11.6 & 48 & 11 & 34.4 & 63 & 35 & 11.9 & 79 & 14 \\
\hline United Kingdom & 90.2 & 0 & 11 & 127.3 & 4 & 17 & 239.1 & 14 & 53 & 47.6 & 15 & 11 \\
\hline United States & 613.5 & 18 & 12 & 960.7 & 25 & 21 & $3,576.2$ & 29 & 14 & 0.0 & & \\
\hline Asia Pacific & 28.1 & 0 & 6 & 21.2 & 0 & 5 & 185.5 & 27 & 23 & 20.6 & 58 & 17 \\
\hline Other Regions & 3.8 & 0 & 1 & 0.2 & 0 & 17 & 25.3 & 1 & 47 & 0.1 & 0 & 12 \\
\hline Total (Non-U.S.) & 590.7 & 5 & 9 & 887.1 & 11 & 26 & 855.8 & 17 & 50 & 437.3 & 18 & 27 \\
\hline Total & $1,204.2$ & 12 & 11 & $1,847.8$ & 18 & 24 & $4,431.9$ & 27 & 21 & 437.3 & 18 & 27 \\
\hline
\end{tabular}


Table IA.5 (continued)

\begin{tabular}{|c|c|c|c|c|c|c|c|c|c|c|c|c|}
\hline \multicolumn{13}{|c|}{ Panel B: By country of sale } \\
\hline \multirow[b]{2}{*}{ Domicile } & \multicolumn{3}{|c|}{ World funds } & \multicolumn{3}{|c|}{ Regional funds } & \multicolumn{3}{|c|}{ Country - domestic funds } & \multicolumn{3}{|c|}{ Country - foreign funds } \\
\hline & $\begin{array}{c}\text { TNA } \\
\text { (\$ billion) }\end{array}$ & $\begin{array}{c}\text { Explicit } \\
\text { indexing } \\
(\%)\end{array}$ & $\begin{array}{c}\text { Closet } \\
\text { indexing } \\
(\%)\end{array}$ & $\begin{array}{c}\text { TNA } \\
\text { (\$ billion) }\end{array}$ & $\begin{array}{c}\text { Explicit } \\
\text { indexing } \\
(\%)\end{array}$ & $\begin{array}{c}\text { Closet } \\
\text { indexing } \\
(\%)\end{array}$ & $\begin{array}{c}\text { TNA } \\
\text { (\$ billion) }\end{array}$ & $\begin{array}{c}\text { Explicit } \\
\text { indexing } \\
(\%)\end{array}$ & $\begin{array}{c}\text { Closet } \\
\text { indexing } \\
(\%)\end{array}$ & $\begin{array}{c}\text { TNA } \\
\text { (\$ billion) }\end{array}$ & $\begin{array}{c}\text { Explicit } \\
\text { indexing } \\
(\%)\end{array}$ & $\begin{array}{c}\text { Closet } \\
\text { indexing } \\
(\%)\end{array}$ \\
\hline Austria & 255.6 & 4 & 9 & 476.8 & 12 & 24 & 71.3 & 16 & 64 & 216.0 & 17 & 28 \\
\hline Belgium & 115.1 & 1 & 15 & 269.1 & 5 & 26 & 17.1 & 1 & 83 & 117.7 & 6 & 31 \\
\hline Canada & 75.7 & 4 & 3 & 17.1 & 4 & 16 & 204.0 & 10 & 56 & 29.7 & 3 & 9 \\
\hline Denmark & 105.2 & 7 & 14 & 251.4 & 12 & 25 & 13.0 & 0 & 77 & 106.9 & 17 & 33 \\
\hline Finland & 109.5 & 3 & 17 & 315.1 & 7 & 27 & 10.6 & 5 & 59 & 146.5 & 6 & 34 \\
\hline France & 214.8 & 8 & 12 & 506.7 & 14 & 24 & 72.7 & 15 & 52 & 230.2 & 17 & 27 \\
\hline Germany & 298.1 & 6 & 9 & 556.8 & 14 & 24 & 78.2 & 13 & 65 & 252.5 & 17 & 29 \\
\hline Ireland & 128.1 & 10 & 15 & 293.0 & 13 & 25 & 21.7 & & & 152.4 & 22 & 24 \\
\hline Italy & 167.7 & 4 & 14 & 363.4 & 7 & 27 & 26.2 & 26 & 56 & 148.7 & 8 & 36 \\
\hline Liechtenstein & 0.0 & 0 & 0 & 0.6 & 1 & 56 & 0.0 & & & 0.8 & 5 & 10 \\
\hline Luxembourg & 252.5 & 7 & 9 & 496.1 & 12 & 26 & 50.0 & & & 249.2 & 16 & 30 \\
\hline Netherlands & 216.0 & 7 & 13 & 441.4 & 15 & 22 & 36.7 & 43 & 38 & 205.8 & 17 & 28 \\
\hline Norway & 98.7 & 2 & 16 & 240.8 & 1 & 30 & 22.6 & 12 & 54 & 120.2 & 1 & 40 \\
\hline Poland & 63.6 & 0 & 17 & 111.1 & 0 & 36 & 5.9 & 0 & 81 & 52.3 & & \\
\hline Portugal & 89.1 & 0 & 20 & 228.7 & 2 & 27 & 3.1 & 0 & 96 & 119.3 & 3 & 41 \\
\hline Spain & 180.0 & 6 & 12 & 403.0 & 11 & 26 & 25.3 & 3 & 81 & 197.6 & 15 & 28 \\
\hline Sweden & 189.0 & 9 & 14 & 410.6 & 11 & 24 & 61.4 & 15 & 67 & 195.1 & 14 & 31 \\
\hline Switzerland & 255.6 & 8 & 9 & 524.8 & 15 & 21 & 79.1 & 29 & 44 & 246.1 & 20 & 26 \\
\hline United Kingdom & 255.9 & 6 & 13 & 539.2 & 12 & 21 & 242.8 & 14 & 52 & 269.4 & 17 & 22 \\
\hline United States & 605.6 & 18 & 12 & 936.3 & 26 & 20 & $3,536.8$ & 29 & 14 & 0.0 & & \\
\hline Asia Pacific & 355.1 & 4 & 13 & 817.1 & 12 & 22 & 559.5 & 68 & 11 & 371.5 & 8 & 25 \\
\hline Other Regions & 30.8 & 0 & 12 & 71.5 & 0 & 13 & 32.8 & 0 & 42 & 28.2 & 0 & 48 \\
\hline Other Countries & $1,032.6$ & 15 & 14 & $2,412.1$ & 13 & 24 & $1,449.8$ & 67 & 18 & 766.0 & 4 & 34 \\
\hline Total (Non-U.S.) & $4,488.6$ & 8 & 13 & $9,746.5$ & 11 & 24 & $3,083.7$ & 49 & 30 & 4,221.9 & 12 & 30 \\
\hline Total & $5,094.2$ & 9 & 13 & $10,682.9$ & 13 & 24 & $6,620.5$ & 38 & 21 & 4,221.9 & 12 & 30 \\
\hline
\end{tabular}




\section{Table IA.6}

Determinants of explicit and closet indexing: robustness by country and benchmark type

This table presents estimates of yearly country-level regressions where the dependent variable is the percentage that explicitly indexed funds represent of the TNA in a country (Explicit Indexing (\% TNA)), the TNA-weighted average total shareholder cost of explicitly indexed funds in a country (Explicit Indexing (Average TSC)), and the percentage that active funds with active share measure below 0.6 represent of the TNA in a country (Closet Indexing (\% TNA)). The sample includes openend equity mutual funds taken from Lipper for which holdings are available in LionShares from 2002 to 2010 . In Panel A the unit of observation is a country of domicile $j$ and benchmark type $b$ in year $t$. In Panel B the unit of observation is a country of sale $k$ and benchmark type $b$ in year $t$. Benchmark types are world funds, regional funds, country - domestic funds (funds investing in their country of domicile) and country - foreign funds (funds investing in a country different from their domicile). Regressions include year dummies. Refer to Appendix A for variable definitions. Robust $t$-statistics are reported in parentheses. *, **, *** reflects significance at the $10 \%, 5 \%$ and $1 \%$ levels.

\begin{tabular}{|c|c|c|c|c|c|c|}
\hline \multicolumn{7}{|c|}{ Panel A: By Country of domicile and benchmark type } \\
\hline & \multicolumn{2}{|c|}{$\begin{array}{c}\text { Explicit indexing } \\
(\% \text { TNA })\end{array}$} & \multicolumn{2}{|c|}{$\begin{array}{l}\text { Explicit indexing } \\
\text { (Average TSC) }\end{array}$} & \multicolumn{2}{|c|}{$\begin{array}{c}\text { Closet indexing } \\
\text { (\% TNA) }\end{array}$} \\
\hline & (1) & $(2)$ & (3) & $(4)$ & $(5)$ & $(6)$ \\
\hline Approval & $\begin{array}{l}0.0183 \\
(1.49)\end{array}$ & & $\begin{array}{c}0.1308^{* *} \\
(2.58)\end{array}$ & & $\begin{array}{l}0.0024 \\
(0.10)\end{array}$ & \\
\hline Judicial & $\begin{array}{c}0.0021^{* *} \\
(2.25)\end{array}$ & & $\begin{array}{c}-0.0218 * * * \\
(-5.57)\end{array}$ & & $\begin{array}{c}-0.0030^{*} \\
(-1.75)\end{array}$ & \\
\hline Fund industry size (log) & & $\begin{array}{c}0.0206^{* * *} \\
(4.32)\end{array}$ & & $\begin{array}{c}-0.0766^{* * *} \\
(-3.84)\end{array}$ & & $\begin{array}{c}-0.0166 * \\
(-1.91)\end{array}$ \\
\hline Fund industry Herfindahl & & $\begin{array}{c}0.3905^{* * *} \\
(3.81)\end{array}$ & & $\begin{array}{c}0.4524 \\
(1.08)\end{array}$ & & $\begin{array}{l}0.2326 \\
(1.23)\end{array}$ \\
\hline GDP per capita (log) & & $\begin{array}{l}0.0003 \\
(0.04)\end{array}$ & & $\begin{array}{l}-0.0366 \\
(-1.18)\end{array}$ & & $\begin{array}{l}-0.0070 \\
(-0.48)\end{array}$ \\
\hline Observations & 491 & 473 & 409 & 409 & 490 & 472 \\
\hline R-squared & 0.023 & 0.064 & 0.104 & 0.123 & 0.080 & 0.102 \\
\hline \multicolumn{7}{|c|}{ Panel B: By country of sale and benchmark type } \\
\hline & \multicolumn{2}{|c|}{$\begin{array}{c}\text { Explicit indexing } \\
\text { (\% TNA) }\end{array}$} & \multicolumn{2}{|c|}{$\begin{array}{l}\text { Explicit indexing } \\
\text { (Average TSC) }\end{array}$} & \multicolumn{2}{|c|}{$\begin{array}{c}\text { Closet indexing } \\
\text { (\% TNA) }\end{array}$} \\
\hline & $(1)$ & $(2)$ & (3) & $(4)$ & $(5)$ & $(6)$ \\
\hline Approval & $\begin{array}{c}0.0943^{* * *} \\
(6.83)\end{array}$ & & $\begin{array}{c}-0.1936 * * * \\
(-5.04)\end{array}$ & & $\begin{array}{c}-0.0596 * * * \\
(-2.68)\end{array}$ & \\
\hline Judicial & $\begin{array}{c}0.0053^{* * *} \\
(5.20)\end{array}$ & & $\begin{array}{c}-0.0352 * * * \\
(-11.82)\end{array}$ & & $\begin{array}{c}-0.0092 * * * \\
(-5.60)\end{array}$ & \\
\hline Fund industry size (log) & & $\begin{array}{c}0.0183^{* * *} \\
(3.66)\end{array}$ & & $\begin{array}{c}-0.1004 * * * \\
(-7.58)\end{array}$ & & $\begin{array}{c}-0.0281 * * * \\
(-3.45)\end{array}$ \\
\hline Fund industry Herfindahl & & $\begin{array}{c}-0.1856 \\
(-1.46)\end{array}$ & & $\begin{array}{c}1.5400^{* * *} \\
(4.81)\end{array}$ & & $\begin{array}{l}0.0230 \\
(0.11)\end{array}$ \\
\hline GDP per capita (log) & & $\begin{array}{c}0.0043 \\
(0.55)\end{array}$ & & $\begin{array}{c}-0.0965 * * * \\
(-4.82)\end{array}$ & & $\begin{array}{l}-0.0116 \\
(-0.90)\end{array}$ \\
\hline Observations & 491 & 491 & 471 & 471 & 490 & 490 \\
\hline R-squared & 0.144 & 0.088 & 0.297 & 0.417 & 0.118 & 0.101 \\
\hline
\end{tabular}




\section{Table IA.7}

Determinants of active management: robustness

This table presents estimates of panel regressions where the dependent variable is a fund's active share at year-end, defined as the percentage of a fund's portfolio holdings that differ from the fund's benchmark. Columns (1) and (2) use the sample of non-U.S. domiciled mutual funds. In columns (3) and (4) the dependent variable is the active share measure calculated as the percentage of portfolio holdings that differ from pure-ETFs that track each benchmark. In columns (5) and (6) the dependent variable is the minimum active share calculated against all possible 88 benchmarks. In columns (7) and (8) the dependent variable is the active share calculated against the aggregate stock portfolio of active funds. Columns (9) and (10) present regressions estimates using weighted least squares where the weights are the fund's total net assets. Columns (11) and (12) present regressions estimates including country fixed effects. Columns (13) and (14) present estimates for the sample of domestic funds. Columns (15) and (16) measure explicit indexing at the country-benchmark type level. The sample includes open-end active equity mutual funds taken from Lipper for which holdings are available in LionShares from 2002 to 2010. In Panel A the unit of observation is a fund's primary share class $i$ domiciled in country $j$ in year $t$. In Panel B the unit of observation is a fund share class $s$ offered for sale in country $k$ in year $t$. Regressions include the fund and country control variables used in Table 3 (coefficients not shown) as well as year and benchmark dummies. Refer to Appendix A for variable definitions. Robust $t$-statistics clustered by country of domicile-year (Panel A) or country of sale-year (Panel B) are reported in parentheses. *, **, *** reflects significance at the $10 \%, 5 \%$ and $1 \%$ levels.

\begin{tabular}{|c|c|c|c|c|c|c|c|c|}
\hline \multicolumn{9}{|l|}{ Panel A: By country of domicile } \\
\hline & \multicolumn{2}{|c|}{ Non-U.S. funds } & \multicolumn{2}{|c|}{ Pure-ETF active share } & \multicolumn{2}{|c|}{ Minimum active share } & \multicolumn{2}{|c|}{ Active share (vs. active) } \\
\hline & $(1)$ & (2) & (3) & (4) & (5) & (6) & $(7)$ & (8) \\
\hline Explicit indexing (\% TNA) & $\begin{array}{l}0.0115 \\
(0.74)\end{array}$ & & $\begin{array}{c}0.0414^{* *} \\
(2.43)\end{array}$ & & $\begin{array}{c}0.0353^{* *} \\
(2.16)\end{array}$ & & $\begin{array}{l}0.0235 \\
(1.30)\end{array}$ & \\
\hline Explicit indexing (Avg. TSC) & & $\begin{array}{c}-0.0210^{* * *} \\
(-4.31)\end{array}$ & & $\begin{array}{c}-0.0255^{* * *} \\
(-4.48)\end{array}$ & & $\begin{array}{c}-0.0275^{* * *} \\
(-4.79)\end{array}$ & & $\begin{array}{c}-0.0297 * * * \\
(-5.50)\end{array}$ \\
\hline Observations & 41,155 & 39,222 & 46,712 & 45,667 & 58,255 & 56,324 & 58,487 & 56,554 \\
\hline \multirow[t]{3}{*}{ R-squared } & 0.620 & 0.621 & 0.598 & 0.601 & 0.566 & 0.566 & 0.620 & 0.619 \\
\hline & \multicolumn{2}{|c|}{ Weighted-least squares } & \multicolumn{2}{|c|}{ Country fixed effects } & \multicolumn{2}{|c|}{ Domestic funds } & \multicolumn{2}{|c|}{ By country-benchmark type } \\
\hline & $(9)$ & $(10)$ & $(11)$ & $(12)$ & $(13)$ & (14) & $(15)$ & $(16)$ \\
\hline Explicit indexing (\% TNA) & $\begin{array}{l}-0.0256 \\
(-0.98)\end{array}$ & & $\begin{array}{l}-0.0113 \\
(-0.30)\end{array}$ & & $\begin{array}{c}0.0641^{*} \\
(1.74)\end{array}$ & & $\begin{array}{l}0.0175 \\
(0.97)\end{array}$ & \\
\hline Explicit indexing (Avg. TSC) & & $\begin{array}{c}-0.0325^{* * *} \\
\quad(-3.37)\end{array}$ & & $\begin{array}{c}-0.0383 * * * \\
(-3.66)\end{array}$ & & $\begin{array}{c}-0.0469 * * \\
(-2.64)\end{array}$ & & $\begin{array}{c}-0.0284 * * * \\
(-4.42)\end{array}$ \\
\hline Observations & 58,487 & 56,554 & 58,931 & 56,554 & 24,825 & 24,156 & 58,487 & 56,554 \\
\hline R-squared & 0.643 & 0.643 & 0.329 & 0.323 & 0.695 & 0.692 & 0.622 & 0.622 \\
\hline
\end{tabular}


Table IA.7 (continued)

\begin{tabular}{|c|c|c|c|c|c|c|c|c|}
\hline \multicolumn{9}{|l|}{ Panel B: By country of sale } \\
\hline & \multicolumn{2}{|c|}{ Non-U.S. funds } & \multicolumn{2}{|c|}{ Pure-ETF active share } & \multicolumn{2}{|c|}{ Minimum active share } & \multicolumn{2}{|c|}{ Active share (vs. active) } \\
\hline & $(1)$ & $(2)$ & (3) & (4) & (5) & (6) & $(7)$ & (8) \\
\hline Explicit indexing (\% TNA) & $\begin{array}{l}0.0085 \\
(1.22)\end{array}$ & & $\begin{array}{c}0.0300^{* * * *} \\
(4.02)\end{array}$ & & $\begin{array}{c}0.0192^{* * *} \\
(2.78)\end{array}$ & & $\begin{array}{c}0.0164 * * \\
(2.14)\end{array}$ & \\
\hline Explicit indexing (Avg. TSC) & & $\begin{array}{c}-0.0087 * * * \\
(-3.81)\end{array}$ & & $\begin{array}{c}-0.0100^{* * *} \\
(-4.16)\end{array}$ & & $\begin{array}{c}-0.0140^{* * *} \\
(-5.14)\end{array}$ & & $\begin{array}{c}-0.0132 * * * \\
(-4.61)\end{array}$ \\
\hline Observations & 372,239 & 364,933 & 362,794 & 356,635 & 420,378 & 413,073 & 443,706 & 435,899 \\
\hline \multirow[t]{3}{*}{ R-squared } & 0.623 & 0.623 & 0.594 & 0.593 & 0.568 & 0.567 & 0.618 & 0.618 \\
\hline & \multicolumn{2}{|c|}{ Weighted-least squares } & \multicolumn{2}{|c|}{ Country fixed effects } & \multicolumn{2}{|c|}{ Domestic funds } & \multicolumn{2}{|c|}{ By country-benchmark type } \\
\hline & (9) & $(10)$ & $(11)$ & $(12)$ & $(13)$ & $(14)$ & (13) & $(14)$ \\
\hline Explicit indexing (\% TNA) & $\begin{array}{c}0.0332 * \\
(1.96)\end{array}$ & & $\begin{array}{c}-0.0028 \\
(-0.21)\end{array}$ & & $\begin{array}{c}0.0229 \\
(0.56)\end{array}$ & & $\begin{array}{c}-0.0109 \\
(-0.98)\end{array}$ & \\
\hline Explicit indexing (Avg. TSC) & & $\begin{array}{l}-0.0087 \\
(-1.64)\end{array}$ & & $\begin{array}{c}-0.0162 * * * \\
(-4.57)\end{array}$ & & $\begin{array}{c}-0.0302^{* * *} \\
(-2.90)\end{array}$ & & $\begin{array}{c}-0.0117^{* * *} \\
(-3.28)\end{array}$ \\
\hline Observations & 423,103 & 415,797 & 423,103 & 415,797 & 56,202 & 55,963 & 423,103 & 415,797 \\
\hline R-squared & 0.641 & 0.640 & 0.158 & 0.159 & 0.664 & 0.664 & 0.617 & 0.616 \\
\hline
\end{tabular}




\section{Table IA.8}

Determinants of the total shareholder costs of active funds: robustness

This table presents estimates of panel regressions where the dependent variable is a fund's yearly total shareholder cost, defined as total expense ratio plus one-fifth of the front-end load. Columns (1)-(3) use the sample of non-U.S. domiciled mutual funds. In columns (4)-(6) the active share measure is calculated as the percentage of portfolio holdings that differ from pure-ETFs that track each benchmark. In columns (7)-(9) the minimum active share is calculated against all possible 88 benchmarks. In columns (10)-(12) the active share is calculated against the aggregate stock portfolio of active funds. Columns (13)-(15) present regressions estimates using weighted least squares where the weights are the fund's total net assets. Columns (16)-(18) present regressions estimates including country fixed effects. Columns (19)-(21) presents estimates for the sample of domestic funds. Columns (22)-(24) measure explicit at the country-benchmark type level. The sample includes open-end active equity mutual funds taken from Lipper for which holdings are available in LionShares from 2002 to 2010. In Panel A the unit of observation is a fund's primary share class $i$ domiciled in country $j$ in year $t$. In Panel B the unit of observation is a fund share class $s$ offered for sale in country $k$ in year $t$. Regressions include the fund and country control variables used in Table 4 (coefficients not shown) as well as year and benchmark dummies. Refer to Appendix A for variable definitions. Robust $t$-statistics clustered by country of domicile-year (Panel A) or country of sale-year (Panel B) are reported in parentheses. *, **, *** reflects significance at the $10 \%, 5 \%$ and $1 \%$ levels.

\begin{tabular}{|c|c|c|c|c|c|c|c|c|c|c|c|c|}
\hline \multicolumn{13}{|l|}{ Panel A: By country of domicile } \\
\hline & \multicolumn{3}{|c|}{ Non-U.S. funds } & \multicolumn{3}{|c|}{ Pure-ETF active share } & \multicolumn{3}{|c|}{ Minimum active share } & \multicolumn{3}{|c|}{ Active share (vs. active) } \\
\hline & $(1)$ & (2) & (3) & (4) & (5) & (6) & (7) & $(8)$ & (9) & $(10)$ & $(11)$ & $(12)$ \\
\hline Explicit indexing (\% TNA) & $\begin{array}{l}-0.0924 \\
(-0.75)\end{array}$ & & & $\begin{array}{l}0.0263 \\
(0.24)\end{array}$ & & & $\begin{array}{l}-0.0647 \\
(-0.52)\end{array}$ & & & $\begin{array}{l}-0.0540 \\
(-0.43)\end{array}$ & & \\
\hline Explicit indexing (Avg. TSC) & & $\begin{array}{c}0.3276 * * * \\
(6.73)\end{array}$ & & & $\begin{array}{c}0.3138^{* * *} \\
(6.23)\end{array}$ & & & $\begin{array}{c}0.3257^{* * *} \\
(7.43)\end{array}$ & & & $\begin{array}{c}0.3288^{* * *} \\
(7.52)\end{array}$ & \\
\hline Closet indexing (\% TNA) & & & $\begin{array}{c}0.0024 \\
(0.02)\end{array}$ & & & $\begin{array}{c}0.1148 \\
(1.01)\end{array}$ & & & $\begin{array}{c}0.2866^{* *} \\
(2.46)\end{array}$ & & & $\begin{array}{c}0.2790^{* *} \\
(2.37)\end{array}$ \\
\hline Active share & $\begin{array}{c}0.5970^{* * *} \\
(11.93)\end{array}$ & $\begin{array}{c}0.6189 * * * \\
(11.85)\end{array}$ & $\begin{array}{c}0.5968 * * * \\
(11.87)\end{array}$ & $\begin{array}{c}0.6156^{* * *} \\
(11.95)\end{array}$ & $\begin{array}{c}0.6327 * * * \\
(11.86)\end{array}$ & $\begin{array}{c}0.6191^{* * *} \\
(11.99)\end{array}$ & $\begin{array}{c}0.5895^{* * *} \\
(13.83)\end{array}$ & $\begin{array}{c}0.6127^{* * *} \\
(14.21)\end{array}$ & $\begin{array}{c}0.6015^{* * *} \\
(13.90)\end{array}$ & $\begin{array}{c}0.5980^{* * *} \\
(13.43)\end{array}$ & $\begin{array}{c}0.662 * * * \\
(14.54)\end{array}$ & $\begin{array}{c}0.610^{* * *} \\
(13.40)\end{array}$ \\
\hline Observations & 41,155 & 39,222 & 41,155 & 46,712 & 45,667 & 46,712 & 58,255 & 56,324 & 58,255 & 58,487 & 56,554 & 58,487 \\
\hline \multirow[t]{3}{*}{ R-squared } & 0.287 & 0.289 & 0.287 & 0.372 & 0.381 & 0.372 & 0.389 & 0.391 & 0.390 & 0.388 & 0.3923 & 0.3897 \\
\hline & \multicolumn{3}{|c|}{ Weighted-least squares } & \multicolumn{3}{|c|}{ Country fixed effects } & \multicolumn{3}{|c|}{ Domestic funds } & \multicolumn{3}{|c|}{ By country-benchmark type } \\
\hline & $(13)$ & $(14)$ & $(15)$ & $(16)$ & $(17)$ & $(18)$ & (19) & $(20)$ & $(21)$ & $(22)$ & $(23)$ & $(24)$ \\
\hline Explicit indexing (\% TNA) & $\begin{array}{l}-0.1276 \\
(-0.67)\end{array}$ & & & $\begin{array}{c}-0.3483^{* *} \\
(-2.21)\end{array}$ & & & $\begin{array}{l}-0.1437 \\
(-0.98)\end{array}$ & & & $\begin{array}{l}0.0102 \\
(0.10)\end{array}$ & & \\
\hline Explicit indexing (Avg. TSC) & & $\begin{array}{c}0.2755^{* * *} \\
\quad(5.07)\end{array}$ & & & $\begin{array}{c}0.0920^{* * *} \\
(2.70)\end{array}$ & & & $\begin{array}{l}-0.0334 \\
(-0.72)\end{array}$ & & & $\begin{array}{c}0.4451^{* * *} \\
(12.94)\end{array}$ & \\
\hline Closet indexing (\% TNA) & & & $\begin{array}{c}0.3311^{* *} \\
(2.25)\end{array}$ & & & $\begin{array}{c}0.2159^{* * *} \\
(2.71)\end{array}$ & & & $\begin{array}{c}0.1273^{*} \\
(1.83)\end{array}$ & & & $\begin{array}{c}0.0222 \\
(0.39)\end{array}$ \\
\hline Active share & $\begin{array}{c}0.5032^{* * *} \\
\quad(6.42)\end{array}$ & $\begin{array}{c}0.5103^{* * *} \\
\quad(6.29)\end{array}$ & $\begin{array}{c}0.5126^{* * * *} \\
\quad(6.43)\end{array}$ & $\begin{array}{c}0.2561^{* * *} \\
\quad(8.45)\end{array}$ & $\begin{array}{c}0.2560^{* * *} \\
\quad(8.10)\end{array}$ & $\begin{array}{c}0.2590 * * * \\
\quad(8.52)\end{array}$ & $\begin{array}{c}0.6249 * * * \\
(14.55)\end{array}$ & $\begin{array}{c}0.6398^{* * *} \\
(14.59)\end{array}$ & $\begin{array}{c}0.6264^{* * *} \\
(14.59)\end{array}$ & $\begin{array}{c}0.6078^{* * *} \\
(13.94)\end{array}$ & $\begin{array}{c}0.6378 * * * \\
(14.21)\end{array}$ & $\begin{array}{c}0.6095 * * * \\
(14.17)\end{array}$ \\
\hline Observations & 58,487 & 56,554 & 58,487 & 58,931 & 56,554 & 58,931 & 24,825 & 24,156 & 24,825 & 58,487 & 56,554 & 58,487 \\
\hline R-squared & 0.513 & 0.513 & 0.513 & 0.415 & 0.403 & 0.415 & 0.426 & 0.387 & 0.426 & 0.390 & 0.399 & 0.390 \\
\hline
\end{tabular}


Table IA.8 (continued)

\begin{tabular}{|c|c|c|c|c|c|c|c|c|c|c|c|c|}
\hline \multicolumn{13}{|l|}{ Panel B: By country of sale } \\
\hline & \multicolumn{3}{|c|}{ Non-U.S. funds } & \multicolumn{3}{|c|}{ Pure-ETF active share } & \multicolumn{3}{|c|}{ Minimum active Share } & \multicolumn{3}{|c|}{ Active share (vs. active) } \\
\hline & $(1)$ & (2) & (3) & (4) & (5) & (6) & $(7)$ & (8) & (9) & $(10)$ & (11) & $(12)$ \\
\hline Explicit indexing (\% TNA) & $\begin{array}{c}-0.3071^{* * *} \\
(-3.55)\end{array}$ & & & $\begin{array}{c}-0.4480 * * * \\
(-5.23)\end{array}$ & & & $\begin{array}{c}-0.4170^{* * *} \\
(-4.27)\end{array}$ & & & $\begin{array}{c}-0.4079 * * * \\
(-3.71)\end{array}$ & & \\
\hline Explicit indexing (Avg. TSC) & & $\begin{array}{c}0.1003^{* * *} \\
(5.00)\end{array}$ & & & $\begin{array}{c}0.0874^{* * *} \\
(4.80)\end{array}$ & & & $\begin{array}{c}0.1261^{* * *} \\
\quad(6.00)\end{array}$ & & & $\begin{array}{c}0.1224^{* * *} \\
(5.32)\end{array}$ & \\
\hline Closet indexing (\% TNA) & & & $\begin{array}{c}-0.1382 \\
(-1.05)\end{array}$ & & & $\begin{array}{c}0.5082 * * * \\
(3.86)\end{array}$ & & & $\begin{array}{c}0.3024^{* *} \\
(2.31)\end{array}$ & & & $\begin{array}{c}0.4601^{* * *} \\
(2.71)\end{array}$ \\
\hline Active share & $\begin{array}{c}0.5830 * * * \\
(24.36)\end{array}$ & $\begin{array}{c}0.5808^{* * * *} \\
(24.00)\end{array}$ & $\begin{array}{c}0.5818^{* * *} \\
(24.18)\end{array}$ & $\begin{array}{c}0.5739 * * * \\
(22.03)\end{array}$ & $\begin{array}{c}0.5728 * * * \\
(21.73)\end{array}$ & $\begin{array}{c}0.5749 * * * \\
(21.89)\end{array}$ & $\begin{array}{c}0.6005^{* * *} \\
(24.22)\end{array}$ & $\begin{array}{c}0.6026^{* * *} \\
(24.05)\end{array}$ & $\begin{array}{c}0.6021^{* * *} \\
(23.99)\end{array}$ & $\begin{array}{c}0.6169 * * * \\
(23.95)\end{array}$ & $\begin{array}{c}0.6171^{* * *} \\
(23.59)\end{array}$ & $\begin{array}{c}0.6204^{* * *} \\
(23.14)\end{array}$ \\
\hline Observations & 372,239 & 364,933 & 372,239 & 362,794 & 356,635 & 362,794 & 420,378 & 413,073 & 420,378 & 443,706 & 435,899 & 443,706 \\
\hline \multirow[t]{3}{*}{ R-squared } & 0.102 & 0.102 & 0.102 & 0.182 & 0.184 & 0.182 & 0.198 & 0.198 & 0.197 & 0.282 & 0.282 & 0.282 \\
\hline & \multicolumn{3}{|c|}{ Weighted-least squares } & \multicolumn{3}{|c|}{ Country fixed effects } & \multicolumn{3}{|c|}{ Domestic funds } & \multicolumn{3}{|c|}{ By country-benchmark type } \\
\hline & (13) & $(14)$ & (15) & (16) & $(17)$ & (18) & (19) & $(20)$ & (21) & (19) & $(20)$ & $(21)$ \\
\hline Explicit indexing (\% TNA) & $\begin{array}{c}-0.6323 * * * \\
(-4.03)\end{array}$ & & & $\begin{array}{l}-0.1062 \\
(-1.53)\end{array}$ & & & $\begin{array}{c}-0.3772 * * \\
(-2.25)\end{array}$ & & & $\begin{array}{c}-0.3041^{* * * *} \\
(-3.49)\end{array}$ & & \\
\hline Explicit indexing (Avg. TSC) & & $\begin{array}{c}0.0829 * * * \\
(3.74)\end{array}$ & & & $\begin{array}{c}0.0277^{* *} \\
(2.04)\end{array}$ & & & $\begin{array}{c}0.1173^{* *} \\
(2.10)\end{array}$ & & & $\begin{array}{c}0.1966^{* * *} \\
(8.75)\end{array}$ & \\
\hline Closet indexing (\% TNA) & & & $\begin{array}{c}1.0300^{* * *} \\
(7.11)\end{array}$ & & & $\begin{array}{l}0.0337 \\
(0.52)\end{array}$ & & & $\begin{array}{c}0.1417 \\
(1.14)\end{array}$ & & & $\begin{array}{c}0.0419 \\
(0.72)\end{array}$ \\
\hline Active share & $\begin{array}{c}0.5367 * * * \\
(14.01)\end{array}$ & $\begin{array}{c}0.5324 * * * \\
\quad(13.77)\end{array}$ & $\begin{array}{c}0.5572 * * * \\
(14.80)\end{array}$ & $\begin{array}{c}0.2068^{* * *} \\
(17.52)\end{array}$ & $\begin{array}{c}0.2070^{* * *} \\
(17.15)\end{array}$ & $\begin{array}{c}0.2071^{* * *} \\
(17.43)\end{array}$ & $\begin{array}{c}0.5844 * * * \\
(16.41)\end{array}$ & $\begin{array}{c}0.5887 * * * \\
(16.40)\end{array}$ & $\begin{array}{c}0.5859 * * * \\
(16.44)\end{array}$ & $\begin{array}{c}0.5848^{* * *} \\
(23.94)\end{array}$ & $\begin{array}{c}0.5859 * * * \\
(23.63)\end{array}$ & $\begin{array}{c}0.5865^{* * * *} \\
(23.84)\end{array}$ \\
\hline Observations & 423,103 & 415,797 & 423,103 & 423,103 & 415,797 & 423,103 & 56,202 & 55,963 & 56,202 & 423,103 & 415,797 & 423,103 \\
\hline R-squared & 0.493 & 0.493 & 0.494 & 0.199 & 0.200 & 0.199 & 0.273 & 0.252 & 0.273 & 0.198 & 0.200 & 0.198 \\
\hline
\end{tabular}




\section{Table IA.9}

Instrumental variables regressions of active management

This table presents estimates of instrumental variables regressions of a fund's active share at year-end. The first-stage dependent variables are the percentage that explicitly indexed funds represent of the TNA in a country (Explicit indexing (\% TNA)) and the TNA-weighted average total shareholder cost of explicitly indexed funds in a country (Explicit indexing (average TSC)). The sample includes open-end active equity mutual funds taken from Lipper for which holdings are available in LionShares from 2002 to 2010. In Panel A the unit of observation is a fund's primary share class $i$ domiciled in country $j$ in year $t$. In Panel B the unit of observation is a fund share class $s$ offered for sale in country $k$ in year $t$. Regressions include the fund and country control variables used in Table 3 as well as year and benchmark dummies. Refer to Appendix A for variable definitions. Robust $t$-statistics clustered by country of domicile-year (Panel A) or country of sale-year (Panel B) are reported in parentheses. $*, * *, * * *$ reflects significance at the $10 \%, 5 \%$ and $1 \%$ levels.

\begin{tabular}{|c|c|c|c|c|}
\hline \multicolumn{5}{|l|}{ Panel A: By country of domicile } \\
\hline & \multicolumn{2}{|c|}{ First stage regression } & \multicolumn{2}{|c|}{ Second stage regression } \\
\hline & $\begin{array}{c}\text { Explicit indexing } \\
\text { (\% TNA) }\end{array}$ & $\begin{array}{c}\text { Explicit indexing } \\
\text { (average TSC) }\end{array}$ & \multicolumn{2}{|c|}{ Active share } \\
\hline & $(1)$ & $(2)$ & $(3)$ & $(4)$ \\
\hline Explicit indexing (\% TNA) & & & $\begin{array}{c}0.9795^{* * * *} \\
\quad(3.04)\end{array}$ & \\
\hline Explicit indexing (average TSC) & & & & $\begin{array}{c}-0.2421 * * * \\
(-3.89)\end{array}$ \\
\hline Financial sophistication & $\begin{array}{c}0.0316^{* *} \\
(2.40)\end{array}$ & $\begin{array}{c}-0.1169 * * \\
(-2.22)\end{array}$ & & \\
\hline DC pension market & $\begin{array}{c}0.0583^{* * *} \\
\quad(4.48)\end{array}$ & $\begin{array}{c}-0.2570 * * * \\
(-3.93)\end{array}$ & & \\
\hline Observations & 56,590 & 54,669 & 56,590 & 54,669 \\
\hline R-squared & 0.666 & 0.758 & 0.211 & 0.230 \\
\hline Instruments F-statistic & 10.04 & 8.63 & & \\
\hline p-value & 0.000 & 0.000 & & \\
\hline Hansen J-statistic & & & 2.604 & 1.041 \\
\hline p-value & & & 0.107 & 0.308 \\
\hline \multicolumn{5}{|l|}{ Panel B: By country of sale } \\
\hline & \multicolumn{2}{|c|}{ First stage regression } & \multicolumn{2}{|c|}{ Second stage regression } \\
\hline & $\begin{array}{c}\text { Explicit indexing } \\
\text { (\% TNA) }\end{array}$ & $\begin{array}{c}\text { Explicit indexing } \\
\text { (average TSC) }\end{array}$ & \multicolumn{2}{|c|}{ Active share } \\
\hline & $(1)$ & $(2)$ & (3) & (4) \\
\hline Explicit indexing (\% TNA) & & & $\begin{array}{c}0.6072 * * * \\
\quad(4.36)\end{array}$ & \\
\hline Explicit indexing (average TSC) & & & & $\begin{array}{c}-0.0612^{* * * *} \\
(-2.78)\end{array}$ \\
\hline Financial sophistication & $\begin{array}{c}0.0246 * * * \\
(4.00)\end{array}$ & $\begin{array}{c}-0.1943^{* * *} \\
(-6.47)\end{array}$ & & \\
\hline DC pension market & $\begin{array}{l}0.0521^{* * * *} \\
\quad(6.96)\end{array}$ & $\begin{array}{c}-0.1116^{* * *} \\
(-4.53)\end{array}$ & & \\
\hline Observations & 420,262 & 412,956 & 420,262 & 412,956 \\
\hline R-squared & 0.558 & 0.685 & 0.110 & 0.122 \\
\hline Instruments F-statistic & 30.60 & 31.56 & & \\
\hline p-value & 0.000 & 0.000 & & \\
\hline Hansen J-statistic & & & 1.545 & 0.921 \\
\hline p-value & & & 0.214 & 0.337 \\
\hline
\end{tabular}




\section{Table IA.10}

Instrumental variables regression of the total shareholder costs of active funds

This table presents estimates of instrumental variables regressions of a fund's yearly total shareholder cost, defined as total expense ratio plus one-fifth of the front-end load. The first-stage dependent variables are the percentage that explicitly indexed funds represent of the TNA in a country (Explicit indexing (\% TNA)), TNA-weighted average total shareholder cost of explicitly indexed funds in a country (Explicit indexing (average TSC)), or percentage that active funds with active share measure below 0.6 represent of the TNA in a country (Closet indexing (\% TNA)). The sample includes open-end active equity mutual funds taken from Lipper for which holdings are available in LionShares from 2002 to 2010. In Panel A the unit of observation is a fund's primary share class $i$ domiciled in country $j$ in year $t$. In Panel B the unit of observation is a fund share class $s$ offered for sale in country $k$ in year $t$. Regressions include the fund and country control variables used in Table 4 as well as year and benchmark dummies. Refer to Appendix A for variable definitions. Robust $t$-statistics clustered by country of domicile-year (Panel A) or country of sale-year (Panel B) are reported in parentheses. *, **, *** reflects significance at the $10 \%, 5 \%$ and $1 \%$ levels.

\begin{tabular}{|c|c|c|c|c|c|c|}
\hline \multicolumn{7}{|l|}{ Panel A: By country of domicile } \\
\hline & \multicolumn{3}{|c|}{ First stage regression } & \multicolumn{3}{|c|}{ Second stage regression } \\
\hline & $\begin{array}{c}\text { Explicit indexing } \\
(\% \text { TNA })\end{array}$ & $\begin{array}{c}\text { Explicit indexing } \\
\text { (Average TSC) }\end{array}$ & $\begin{array}{c}\text { Closet indexing } \\
\text { (\% TNA) }\end{array}$ & \multicolumn{3}{|c|}{ Total shareholder cost } \\
\hline & $(1)$ & $(2)$ & $(3)$ & (4) & (5) & (6) \\
\hline Explicit indexing (\% TNA) & & & & $\begin{array}{c}-4.3860 * * * \\
(-3.58)\end{array}$ & & \\
\hline Explicit indexing (avg. TSC) & & & & & $\begin{array}{c}0.6938 * * * \\
\quad(3.36)\end{array}$ & \\
\hline Closet indexing (\% TNA) & & & & & & $\begin{array}{l}1.3072 * * * \\
(3.99)\end{array}$ \\
\hline Financial sophistication & $\begin{array}{l}0.0603 * * * \\
\quad(4.62)\end{array}$ & $\begin{array}{c}-0.2664 * * * \\
(-4.05)\end{array}$ & $\begin{array}{c}-0.1759 * * * \\
(-11.68)\end{array}$ & & & \\
\hline DC pension market & $\begin{array}{c}0.0321^{* *} \\
(2.46)\end{array}$ & $\begin{array}{c}-0.1229 * * \\
(-2.32)\end{array}$ & $\begin{array}{c}-0.0244 \\
(-1.34)\end{array}$ & & & \\
\hline Observations & 56,590 & 54,669 & 56,590 & 56,590 & 54,669 & 56,590 \\
\hline R-squared & 0.668 & 0.752 & 0.723 & 0.236 & 0.329 & 0.310 \\
\hline Instruments F-statistic & 10.67 & 9.17 & 72.13 & & & \\
\hline p-value & 0.000 & 0.000 & 0.000 & & & \\
\hline Hansen J-statistic & & & & 2.659 & 0.172 & 1.798 \\
\hline p-value & & & & 0.103 & 0.679 & 0.180 \\
\hline \multicolumn{7}{|l|}{ Panel B: By country of sale } \\
\hline & \multicolumn{3}{|c|}{$\begin{array}{l}\text { First stage regression } \\
\end{array}$} & \multicolumn{3}{|c|}{ Second stage regression } \\
\hline & $\begin{array}{c}\text { Explicit indexing } \\
\text { (\% TNA) }\end{array}$ & $\begin{array}{c}\text { Explicit indexing } \\
\text { (TSC) }\end{array}$ & $\begin{array}{c}\text { Closet indexing } \\
\text { (\% TNA) }\end{array}$ & \multicolumn{3}{|c|}{ Total shareholder cost } \\
\hline & $(1)$ & $(2)$ & $(3)$ & $(4)$ & (5) & (6) \\
\hline Explicit indexing (\% TNA) & & & & $\begin{array}{c}-1.1098 * * * \\
(-2.61)\end{array}$ & & \\
\hline Explicit indexing (avg. TSC) & & & & & $\begin{array}{c}0.1695 * * \\
\quad(2.28)\end{array}$ & \\
\hline Closet indexing (\% TNA) & & & & & & $\begin{array}{l}0.8339 * * * \\
\quad(2.85)\end{array}$ \\
\hline Financial sophistication & $\begin{array}{l}0.0518 * * * \\
\quad(6.95)\end{array}$ & $\begin{array}{c}-0.1108 * * * \\
(-4.54)\end{array}$ & $\begin{array}{c}-0.0840 * * * \\
(-9.45)\end{array}$ & & & \\
\hline DC pension market & $\begin{array}{l}0.0247 * * * \\
\quad(4.00)\end{array}$ & $\begin{array}{c}-0.1944 * * * \\
(-6.47)\end{array}$ & $\begin{array}{c}-0.0242 * * * \\
(-3.85)\end{array}$ & & & \\
\hline Observations & 420,262 & 412,956 & 420,262 & 420,262 & 412,956 & 420,262 \\
\hline R-squared & 0.557 & 0.685 & 0.546 & 0.168 & 0.170 & 0.169 \\
\hline Instruments F-statistic & 30.52 & 31.73 & 45.53 & & & \\
\hline p-value & 0.000 & 0.000 & 0.000 & & & \\
\hline Hansen J-statistic & & & & 0.263 & 1.921 & 0.022 \\
\hline p-value & & & & 0.608 & 0.166 & 0.882 \\
\hline
\end{tabular}




\section{Table IA.11}

Determinants of the performance of active funds: robustness

This table provides presents estimates of panel regressions where the dependent variable is the yearly fund performance. Column (1) uses benchmark-adjusted return which is the difference between the fund return and its benchmark return. Column (2) uses four-factor alphas estimated using excess returns. Column (3) uses the information ratio. All other columns use benchmark-adjusted return four-factor alphas. Column (4) includes the R-squared measure of Amihud and Goyenko (2013). In column (5) the active share measure is calculated as the percentage of portfolio holdings that differ from pure-ETFs that track each benchmark. In column (6) the minimum active share is calculated against all possible 88 benchmarks. In column (7) the active share is calculated against the aggregate stock portfolio of active funds. Column (8) presents regressions estimates using weighted least squares where the weights are the fund's total net assets. Column (9) uses the sample of non-U.S. domiciled mutual funds. Column (10) presents regression estimates including country fixed effects. Column (11) presents estimates for the sample of domestic funds. The sample includes open-end active equity mutual funds taken from Lipper for which holdings are available in LionShares from 2002 to 2010. In Panel A the unit of observation is a fund's primary share class $i$ domiciled in country $j$ in year $t$. In Panel B the unit of observation is a fund share class $s$ offered for sale in country $k$ in year $t$. All explanatory variables are lagged by one period. Regressions include the fund and country control variables used in Table 7 (coefficients not shown) as well as year and benchmark dummies. Refer to Appendix A for variable definitions. Robust $t$-statistics clustered by country of domicile-year (Panel A) or country of sale-year (Panel B) are reported in parentheses. *, **, *** reflects significance at the $10 \%, 5 \%$ and $1 \%$ levels.

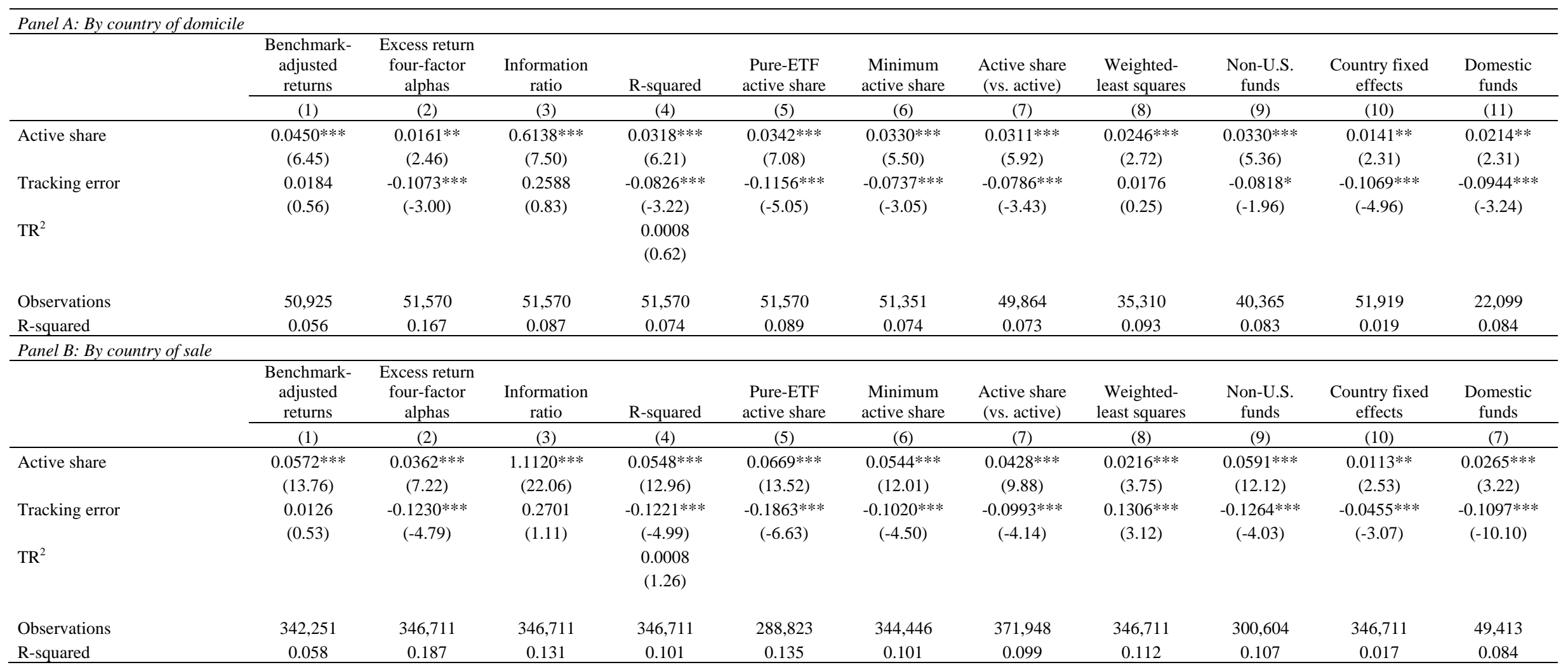




\section{Table IA.12}

Differences-in-differences performance estimates using the Passage of Pension Acts

This table presents differences-in-differences estimates where the dependent variable is a fund's yearly benchmark-adjusted return four-factor alpha. Benchmark-adjusted return is the difference between the fund net return and its benchmark return. Fourfactor alphas are estimated using three years of past monthly benchmark-adjusted fund returns in U.S. dollars with regional factors (Asia, Europe, North America or Emerging Markets) or world factors in the case of world funds. The sample includes open-end active equity mutual funds taken from Lipper for which holdings are available in LionShares from 2002 to 2010. In column (1) the unit of observation is a fund's primary share class $i$ domiciled in country $j$ in year $t$. In column (2) the unit of observation is a fund share class $s$ offered for sale in country $k$ in year $t$. Post pension act (year $>=0$ ) is a dummy variable that equals one if a fund's country has passed a pension act that year or earlier. Regressions include year and fund fixed effects, and the fund and country control variables used in Table 7 (coefficients not shown). Refer to Appendix A for variable definitions. Robust $t$-statistics clustered by country of domicile-year (Panel A) or country of sale-year (Panel B) are reported in parentheses. $*, * *, * * *$ reflects significance at the $10 \%, 5 \%$ and $1 \%$ levels.

\begin{tabular}{lcc}
\hline & By country of domicile & By country of sale \\
\cline { 2 - 3 } & $(1)$ & $(2)$ \\
\hline Post pension act $($ year $>=0)$ & $0.0255^{* *}$ & $0.0343^{* * *}$ \\
Active share & $(1.98)$ & $(4.05)$ \\
& 0.0235 & $0.0413^{* * *}$ \\
Post pension act $($ year $>=0) \times$ Active share & $(1.32)$ & $(3.42)$ \\
& -0.0235 & $-0.0400^{* * *}$ \\
Tracking error & $(-1.39)$ & $(-3.50)$ \\
& -0.1030 & -0.0480 \\
Observations & $(-1.20)$ & $(-0.88)$ \\
R-squared & & \\
\hline
\end{tabular}

